\title{
Superior antimitogenic and chemosensitization activities of the combination treatment of the histone deacetylase inhibitor apicidin and proteasome inhibitors on human colorectal cancer cells
}

\author{
MOHAMED-SALAH I. ABAZA ${ }^{1}$, ABDUL-MAJEED BAHMAN ${ }^{1}$ and RAJA'A AL-ATTIYAH ${ }^{2}$ \\ ${ }^{1}$ Molecular Biology Program, Department of Biological Sciences, Faculty of Science, \\ ${ }^{2}$ Department of Microbiology, Faculty of Medicine, Kuwait University, Safat, Kuwait
}

Received July 22, 2013; Accepted September 13, 2013

DOI: $10.3892 /$ ijo.2013.2146

\begin{abstract}
Despite the effectiveness of histone deacetylase inhibitors, proteasome inhibitors and cytotoxic drugs on human cancers, none of these types of treatments by themselves has been sufficient to eradicate the disease. The combination of different modalities may hold enormous potential for eliciting therapeutic results. In the current study, we examined the effects of treatment with the histone deacetylase inhibitor (HDACI) apicidin (APC) in combination with proteasome inhibitors on human colorectal cancer cells. The molecular mechanisms of the combined treatments and their potential to sensitize colorectal cancer cells to chemotherapies were also investigated. Cancer cells were exposed to the agents alone and in combination, and cell growth inhibition was determined by MTT and colony formation assays. HDAC, proteasome and $\mathrm{NF}-\mathrm{KB}$ activities as well as reactive oxygen species (ROS) were monitored. Cell cycle perturbation and induction of apoptosis were assessed by flow cytometry. The expression of cell cycle/apoptosis- and cytoprotective/stress-related genes was determined by quantitative PCR and EIA, respectively. The potentiation of cancer cell sensitivity to chemotherapies upon APC/PI combination treatment was also studied. The combination of APC and MG132, PI-1 or epoxomicin potently inhibited cancer cell growth, disrupted the cell cycle, induced apoptosis, decreased NF- $\mathrm{kB}$ activity and increased ROS production. These events were accompanied by the altered expression of genes associated with the cell cycle, apoptosis and cytoprotection/stress regulation. The combination treatment markedly enhanced the chemosensitivity of colorectal
\end{abstract}

Correspondence to: Dr Mohamed-Salah I. Abaza, Kuwait University, Faculty of Science, Department of Biological Sciences, Molecular Biology Program, P.O. Box 5969, Safat 13060, Kuwait

E-mail: abazams@yahoo.com

Key words: colorectal cancer, histone deacetylase inhibitor apicidin, proteasome inhibitors, cell cycle, apoptosis, molecular mechanisms, chemosensitization cancer cells $\left(50-3.7 \times 10^{4}\right.$-fold) in a drug-, APC/PI combination- and colorectal cancer subtype-dependent manner. The results of this study have implications for the development of combinatorial treatments that include HDACIs, PIs and conventional chemotherapeutic drugs, suggesting a potential therapeutic synergy with general applicability to various types of cancers.

\section{Introduction}

Histone deacetylase inhibitors (HDACIs) and proteasome inhibitors (PIs) have recently emerged as new groups of therapeutic agents that are effective in treating a variety of malignancies (1). HDACIs are anticancer drugs that have moved rapidly through clinical development, and in 2006, vorinostat (SAHA, Zolinza) was approved by the FDA for the treatment of cutaneous T cell lymphoma (2). The targets of these compounds include class I, II and IV HDACs, which function in deacetylating histone proteins to induce chromatin remodeling and altered gene transcription. Numerous non-histone proteins can also be modified by acetylation, and thus, the inhibition of HDAC activity can affect various molecular processes. This broad effect on protein function may account for the pleiotropic responses generated by HDACIs, including the induction of tumor cell apoptosis, cell cycle arrest, antitumor activity in vivo, cell differentiation, morphological changes in oncogene-transformed cells, invasion and angiogenesis (3).

The ability of HDACIs to selectively induce tumor cells to undergo apoptosis has been key to their therapeutic efficacy in pre-clinical models. Moreover, HDACIs can augment the apoptotic effects of other anticancer agents that have diverse molecular targets. Although HDACIs are promising anticancer drugs, particularly given their ability to be combined with other agents, identifying the key molecular events that determine the biological response of cells to HDACI treatment remains a challenge (3).

APC, an HDACI isolated from Fusarium sp., was first reported to be a reversible inhibitor of the in vitro development of apicomplexan parasites. APC acts by inhibiting the HDAC enzyme of the parasite, and it was later shown to promote the anti-proliferative activity and differentiation of mammalian 
cells (4). APC has been shown to exhibit antitumor activities in several human cancers, including leukemia, cervical cancer, gastric cancer and breast cancer (5). In addition, APC has been found to reverse the transformation of the human cervical cancer cells, HeLa and H-ras-transformed human breast cancer cells (6). Studies have demonstrated that APC induces apoptosis through the selective induction of Fas/Fas ligand, resulting in the release of cytochrome $\mathrm{c}$ from the mitochondria and the subsequent activation of caspase-9 and caspase-3 (7). Very recently, APC has been shown to induce apoptosis by endoplasmic stress and mitochondrial dysfunction via PLC $\gamma 1$ activation, $\mathrm{Ca}^{2+}$ release, and reactive oxygen species generation (8).

Accumulating evidence has suggested that transcriptional activation by HDACIs requires a mechanism other than chromatin remodeling, such as through histone hyperacetylation, which is associated with protein kinase signaling pathways (9), or acetylation of non-histone proteins, including p53 or $\mathrm{NF}-\kappa \mathrm{B}(10)$. The $\mathrm{NF}-\kappa \mathrm{B}$ signaling pathway is appreciated as one of the pivotal modulators of specific gene expression and differential cellular responses by HDACIs.

$N F-\kappa B$ is a well-known transcription factor that regulates the expression of a large number of genes in response to a variety of cellular conditions. Recent studies have demonstrated that NF- $\kappa \mathrm{B}$ provides an anti-apoptotic signal in many different cancer cells (11). NF- $\kappa \mathrm{B}$ is thought to reside in the cytoplasm in an inactive form, bound by the $\mathrm{I} \kappa \mathrm{B}$ family of inhibitory proteins (12). However, it may shuttle between the nucleus and cytoplasm in unstimulated cells (13). Stimulation of cells with specific inducers activates the I $\kappa \mathrm{B}$ kinase (IKK) complex, leading to the phosphorylation of serines 32 and 36 of $\mathrm{I} \kappa \mathrm{B} \alpha$ or serines 19 and 23 of $\mathrm{I} \kappa \mathrm{B} \beta$ (14). This phosphorylation event triggers rapid ubiquitination and subsequent degradation of $\mathrm{I} \kappa \mathrm{B}$ proteins through the $26 \mathrm{~S}$ proteasome complex, allowing the free $\mathrm{NF}-\kappa \mathrm{B}$ protein to translocate into the nucleus and activate the transcription of its target genes (15). The interaction of $N F-\kappa B$ with histone acetyltransferase (HAT)-containing coactivators, including $\mathrm{p} 300 / \mathrm{CBP}$, the steroid receptor-coactivator-1, and the p300/CBS-associated factor, has been shown to activate transcription. Previously, it has been reported that the acetylation of NF- $\kappa \mathrm{B}$ is responsible for sustaining NF- $\kappa \mathrm{B}-$ dependent transcription (16), and this process is regulated by the HDAC family of proteins, including HDAC-1, -2 and -3 (17).

The proteasome is a proteoly tic complex that is responsible for the intracellular degradation of numerous ubiquitinated proteins that are involved in apoptosis and cell cycle regulation. Bortezomib (Velcad; Millennium Pharmaceuticals, Boston, MA, USA), a first-class proteasome inhibitor that is approved by the FDA for the treatment of multiple myeloma and mantel cell lymphoma, acts by targeting the catalytic $20 \mathrm{~S}$ core of the proteasome and inducing apoptosis in cancer cells (18). Among other mechanisms, proteasome inhibitors lead to the cytoplasmic accumulation of the $\mathrm{I} \kappa \mathrm{B}$ protein, resulting in reduced $\mathrm{NF}-\kappa \mathrm{B}$ activity. The purpose of the current study was to determine whether the small-molecule proteasome inhibitors, MG132, P1-1 and EPM, could sensitize colorectal cancer cells to APC-mediated apoptosis. We also assessed whether combined treatments involving APC and the MG132, PI-1, and EPM PIs could sensitize colorectal cancer cells to conventional chemotherapeutic drugs and induce them to undergo apoptosis. Finally, the potential underlying molecular mechanisms that control the cell cycle, apoptosis, survival, and stress-regulatory pathways were investigated.

\section{Materials and methods}

Cell culture. Human colorectal cancer cell lines (SW1116 and SW837) and normal human fibroblasts (CRL1554) were obtained from the ATCC (American Type Culture Collection, VA, USA). The SW1116 and SW837 cell lines were cultivated in $90 \%$ Leibovitz's L15 medium containing $10 \%$ fetal bovine serum. The L15 medium was formulated for use in a free gas exchange with atmospheric air. The CRL1554 cells were cultivated in Dulbecco's modified Eagle's medium (90\%) containing fetal bovine serum $(10 \%)$.

Chemicals. Apicidin [cyclo(N-O-methyl-L-tryptophanyl-Lisoleucinyl-D-pipecolinyl-L-2-amino-8-oxodecanoyl)] was purchased from Sigma (St. Louis, MO, USA). The following proteasome inhibitors: MG132, proteasome inhibitor 1 (PI-1) and epoxomicin (EPM) were obtained from Biomol International, Enzo Life Sciences International, Inc. (Plymouth Meeting, PA, USA). Falcon plastic ware was purchased from BD Biosciences (San Jose, CA, USA). Trypsin, Leibovitz's L-15 and EMEM media, fetal bovine serum (FBS), and penicillin/ streptomycin (200X solutions) were obtained from Mediatech, Inc. (Herndon, VA, USA). An Annexin V-FITC apoptosis detection kit was obtained from BD Hoffmann-La Roche, Inc. (Nutley, NJ, USA). A DNA-prep kit was obtained from Beckman Coulter (Miami, FL, USA). Primers, Taqman probes and all other reagents for RT-PCR and real-time qPCR were obtained from Applied Biosystems (Foster City, CA, USA). Cayman's NF- $\kappa$ B (p65) transcription factor assay kit was obtained from Cayman Chemical (Ann Arbor, MI, USA). HDAC activity assay and nuclear/cytosol fractionation kits were obtained from BioVision, Inc. (Milpitas, CA, USA). The $20 \mathrm{~S}$ proteasome assay kit for drug discovery was purchased from Biomol International, Enzo Life Sciences International, Inc. PhosphoDetect ${ }^{\mathrm{TM}}$ JNK, PhosphoDetect ERK1/2 and PhosphoDetect Akt ELISA kits were obtained from Calbiochem-Novabiochem (Beeston, Nottingham, UK). All other chemicals were purchased from Sigma Chemicals (St. Louis, MO, USA).

Cell proliferation. The effects of the proteasome inhibitors on the antimitogenic activity of APC on colorectal cancer cells was evaluated by the 3-(4, 5-dimethylthiazol-2-yl)-2, 5-diphenyltetrazolium bromide (MTT) assay as previously described (19). Cancer cells were incubated with various concentrations of APC $(0.06-1.0 \mu \mathrm{M})$ for $24 \mathrm{~h}$ followed by incubation with MG132 (0.15,0.3 $\mu \mathrm{M})$, PI-1 (7.8, 15.6 nM) or EPM (2.8, 5.6 nM) for $72 \mathrm{~h}$. The culture media were then discarded, and $100 \mu \mathrm{l}$ of MTT ( $5 \mathrm{mg} / \mathrm{ml}$ in culture medium, sterile-filtered) was added to each well. The plate was then incubated for $4 \mathrm{~h}$ at $37^{\circ} \mathrm{C}$. The MTT solution was aspirated, and the resulting formazan crystals were dissolved by incubation for $20 \mathrm{~min}$ in $200 \mu \mathrm{l} /$ well of DMSO: ethanol (1:1 v/v) at ambient temperature. Changes in absorbance were measured at $\lambda 540$ and $650 \mathrm{~nm}$. Control cells were incubated in media supplemented with DMSO at a final concentration of $0.2 \%$; the growth and survival of cells are not affected at this concentration of DMSO. 
Colony formation assay. The effect of APC, proteasome inhibitors (MG132, PI-1 or EPM) and APC/PI combinations on the colony formation of colorectal cancer cells was determined by a colony formation assay as previously described (19). SW1116 and SW837 cells were plated $\left(2.5 \times 10^{5}\right.$ cells $\left./ \mathrm{ml}\right)$ in 24 -well plates and incubated in a non- $\mathrm{CO}_{2}$ incubator for $18 \mathrm{~h}$ followed by further incubation for $24 \mathrm{~h}$ with APC $(3.4 \mu \mathrm{M})$, proteasome inhibitors [MG132 (1.5 $\mu \mathrm{M})$, PI-1 $(36 \mathrm{nM})$ or EPM $(26 \mathrm{nM})]$ and APC/PI combinations. The cells were then trypsinized, counted, plated at 500 cells $/ \mathrm{ml}$ in a 6-well plate, and incubated in a non- $\mathrm{CO}_{2}$ incubator for 10-14 days. The treated cells were fixed in $100 \%$ methanol for $30 \mathrm{~min}$ at room temperature and stained with $0.1 \%$ crystal violet for $1 \mathrm{~h}$, and the stained colonies were counted and compared with a control.

The effect of APC, proteasome inhibitors (MG132, PI-1 and EPM) and APC/PI combinations on normal human fibroblast cells (CRL1554) was also monitored as described above using an inverted microscope and an MTT assay.

HDAC activity. The colorimetric HDAC activity assay kit (BioVision, Inc.) was used to monitor histone deacetylase activity in cancer cell nuclear extracts according to the manufacturer's instructions. The SW1116 and SW837 cancer cell lines $\left(2.5 \times 10^{5}\right.$ cells $\left./ \mathrm{ml}\right)$ were plated in 24 -well plates and incubated in a non- $\mathrm{CO}_{2}$ incubator for $18 \mathrm{~h}$ followed by treatment with APC $(3.4 \mu \mathrm{M})$ for $24 \mathrm{~h}$. The nuclear extracts of both untreated and APC-treated cells $(50 \mu \mathrm{l})$ were diluted to $85 \mu \mathrm{l}$ (final volume) with $\mathrm{ddH}_{2} \mathrm{O}$ and plated in a 96 -well plate. For background reading, only $85 \mu \mathrm{l}$ of $\mathrm{ddH}_{2} \mathrm{O}$ was added. A HeLa cell nuclear extract $(10 \mu \mathrm{l})$ was diluted with $75 \mu \mathrm{l}$ of $\mathrm{ddH}_{2} \mathrm{O}$ and used as a positive control. For the negative control, the tested nuclear extract was diluted into $83 \mu \mathrm{l}$, and then $2 \mu \mathrm{l}$ of TSA (HDACI, $1 \mathrm{mM}$ ) was added; alternatively, a known sample containing no HDAC activity was used. Ten microliters of the 10X HDAC assay buffer and $5 \mu \mathrm{l}$ of the HDAC colorimetric substrate [BocLys (Ac)-pNA, $10 \mathrm{mM}$ ] was added, the solution was mixed thoroughly, and the plates were incubated at $37^{\circ} \mathrm{C}$ for $1 \mathrm{~h}$. The reaction was stopped by adding $10 \mu \mathrm{l}$ of lysine developer, and the plates were incubated at $37^{\circ} \mathrm{C}$ for $30 \mathrm{~min}$. The plates were then read in an ELISA plate reader at 400 or $405 \mathrm{~nm}$.

Proteasome activity. Proteasome activity in the cancer cell extracts was monitored using the 20S proteasome assay kit for drug discovery according to the manufacturer's instructions. SW1116 and SW837 cells $\left(2.5 \times 10^{5}\right.$ cells $\left./ \mathrm{ml}\right)$ were plated in 24-well plates and incubated in a non- $\mathrm{CO}_{2}$ incubator for $18 \mathrm{~h}$ followed by treatment with proteasome inhibitors [MG132 $(1.5 \mu \mathrm{M}), \mathrm{PI}-1(36 \mathrm{nM})$ or EPM $(26 \mathrm{nM})]$ for $24 \mathrm{~h}$. Cell extracts of untreated and proteasome inhibitor-treated cancer cells were prepared using a nuclear/cytosolic fractionation kit (BioVision, Inc.). The cytosolic extracts $(0.5 \mu \mathrm{g})$ and positive and negative controls were then incubated with $75 \mu \mathrm{M}$ proteasome substrate (Suc-LLVY-AMC) in $100 \mu \mathrm{l}$ of assay buffer $(20 \mathrm{mM}$ Tris- $\mathrm{HCl}$, $\mathrm{pH} 8.0$ ) for $90 \mathrm{~min}$ at $37^{\circ} \mathrm{C}$. A VersaFluor ${ }^{\mathrm{TM}}$ fluorometer with excitation at $\lambda 360 \mathrm{~nm}$ and emission at $\lambda 460 \mathrm{~nm}$ (Bio-Rad) was used to monitor fluorescence release from AMC (7-amido-4methyl-coumarin).

$N F-\kappa B$ activity. NF- $\kappa \mathrm{B}$ (p65) activity was determined by Cayman's NF- $\kappa \mathrm{B}$ (p65) transcription factor assay according to the manufacturer's instructions. SW1116 and SW837 cells $\left(2.5 \times 10^{5}\right.$ cells $\left./ \mathrm{ml}\right)$ were plated in $24-w e l l$ plates and incubated in a non- $\mathrm{CO}_{2}$ incubator for $18 \mathrm{~h}$. The cells were then incubated with APC $(3.4 \mu \mathrm{M})$, proteasome inhibitors [MG132 $(1.5 \mu \mathrm{M})$, PI-1 (36 nM) or EPM (26 nM)] and APC/PI combinations for $24 \mathrm{~h}$, and nuclear extracts were purified using a nuclear/cytosol fractionation kit. A specific double-stranded DNA sequence containing the $\mathrm{NF}-\kappa \mathrm{B}$ response element was immobilized onto the wells of a 96-well plate as part of the assay. A specific primary antibody directed against NF- $\mathrm{B}$ (p65) was used for detection in the nuclear extracts or in a positive control, and a second antibody conjugated to HRP was used for the readout at $\lambda 450 \mathrm{~nm}$.

Reactive oxygen species (ROS) assay. ROS were analyzed as previously described (8) using 2', 7'-dichlorofluorescein diacetate (DCFH-DA) (Sigma Chemicals). DCFH-DA is a stable, non-fluorescent cell-permeable compound that becomes fluorescent (dichlorofluorescein) in the presence of active radicals and emits green fluorescence upon excitation at $485 \mathrm{~nm}$. The extent of ROS generation was measured by quantifying fluorescence intensity. SW1116 and SW837 cells $\left(2.5 \times 10^{5}\right.$ cells $\left./ \mathrm{ml}\right)$ were plated in $24-w e l l$ plates and incubated in a non- $\mathrm{CO}_{2}$ incubator for $18 \mathrm{~h}$ before treatment with APC $(3.4 \mu \mathrm{M})$, proteasome inhibitors [MG132 $(1.5 \mu \mathrm{M})$, PI-1 (36 $\mathrm{nM})$ or EPM $(26 \mathrm{nM})]$ and APC/PI combinations (or solvent alone) for $48 \mathrm{~h}$. The cells were subsequently washed and incubated with $10 \mu \mathrm{M}$ DCFH-DA in phosphate buffered saline at $37^{\circ} \mathrm{C}$ for $30 \mathrm{~min}$. Fluorescence was analyzed on a microtiter plate reader at 485- $\mathrm{nm}$ excitation and 535-nm emission. Production of ROS was determined by comparing the intensity of fluorescence between treated and untreated cells. The functional role of ROS generation on cell death was assessed using the free radical scavenger, L-N-acetylcysteine (L-NAC) (Sigma Chemicals). Cells were preincubated with $15 \mathrm{mM}$ L-NAC for $3 \mathrm{~h}$, treated with APC, PIs and APC/PI combinations for $48 \mathrm{~h}$ and assessed for cell death as described above.

Cell cycle analysis. The distribution of cells in cell cycle phases $\left(\mathrm{G}_{0} / \mathrm{G}_{1}, \mathrm{~S}\right.$, and $\left.\mathrm{G}_{2} / \mathrm{M}\right)$ was determined by flow cytometry by measuring the DNA content of nuclei labeled with propidium iodide as previously described (20). SW1116 cancer cells $\left(2.5 \times 10^{5}\right.$ cells $\left./ \mathrm{ml}\right)$ were plated in $24-$ well plates and incubated at $37^{\circ} \mathrm{C}$ in a non- $\mathrm{CO}_{2}$ incubator. Eighteen hours after seeding the cells in culture, the cells were treated with APC $(3.4 \mu \mathrm{M})$, proteasome inhibitors [MG132 $(1.5 \mu \mathrm{M}), \mathrm{PI}-1$ (36 nM) or EPM $(26 \mathrm{nM})]$ and APC/PI combinations for $24 \mathrm{~h}$. Untreated and drug-treated cells were collected by trypsinization, washed with cold phosphate buffered saline (PBS) and counted. A DNA-prep kit (Beckman Coulter) and a DNA-prep EPICS workstation (Beckman Coulter) were used to process the cells as follows: the cells were treated with a cell-membrane permeabilizing agent followed by propidium iodide and RNase and incubated at room temperature for $15 \mathrm{~min}$ before analysis by flow cytometry (Beckman Coulter, Nyon, Switzerland). The percentage of cells in various cell cycle phases was calculated using the Phoenix statistical software package with advanced DNA cell cycle software (Phoenix Flow System, San Diego, CA, USA). 
Assessment of apoptosis. Induction of apoptosis in colorectal cancer cells treated with APC, PIs and APC/PI combinations was determined using an Annexin V-FITC apoptosis detection kit according to the manufacturer's instructions. SW1116 cancer cells $\left(2.5 \times 10^{5}\right.$ cells $\left./ \mathrm{ml}\right)$ were plated in 24 -well plates and incubated at $37^{\circ} \mathrm{C}$ in a non- $\mathrm{CO}_{2}$ incubator. The cells were then treated with APC $(3.4 \mu \mathrm{M})$, proteasome inhibitors [MG132 $(1.5 \mu \mathrm{M}), \mathrm{PI}-1$ (36 $\mathrm{nM})$ or EPM $(26 \mathrm{nM})]$ and APC/PI combinations for $24 \mathrm{~h}$. Control and treated cells were resuspended in a $100 \mu \mathrm{l}$ staining solution containing Annexin V-FITC and propidium iodide in HEPES buffer, incubated at room temperature for $15 \mathrm{~min}$, and analyzed by flow cytometry. Annexin V binds to cells expressing phosphatidylserine on the outer layer of the cell membrane, whereas propidium iodide stains the cellular DNA of cells with a compromised cell membrane. This allows the discrimination of live cells (unstained with either fluorochrome) from apoptotic cells (stained only with Annexin V) and necrotic cells (stained with both Annexin V and propidium iodide).

mRNA expression of genes associated with apoptosis and cell cycle regulation. Expression of cell cycle- and apoptosis-associated genes in control and drug-treated cells was determined by real-time polymerase chain reaction (qRT-PCR) using an ABI 7000 SDS system (Applied Biosystems) and the comparative $\Delta \Delta \mathrm{Ct}$ method (19). Ready-made assays-on-demand that target specific genes with probes and primers were obtained from Applied Biosystems. The targets and their Applied Biosystems assay numbers for the cell cycle regulatory genes were: $c d k 1$ (Hs00364293_m1), cdk2 (Hs00608082_m1), cdk4 (Hs00364847_m1), cdk6 (Hs00608037_m1.), cdc25A (Hs00153168_m1),p15 (Hs00394703_m1),p19 (Hs00176481_ m1), p21 (Hs00355782_m1), and p27 (Hs00197366_m1).

The targets and their Applied Biosystems assay numbers for the pro-apoptotic, anti-apoptotic and caspase genes were: Bax (Hs00180269_m1), Bim (Hs00375807_m1), Apaf1 (Hs00559441_m1), cIAP-1 (Hs0023691_m1), c-IAP-2 (Hs00985029_m1), Bcl2 (Hs00608023_m1), $x$-IAP (Hs00236913_m1), casp2 (Hs 00154242_m1), casp3 (Hs00234387_m1), casp6 (Hs00154250_m1), casp7 (Hs00169152_m1), and casp9 (Hs00154260_m1). GAPDH was used as an endogenous control to normalize the expression values for each sample. For the comparative $\mathrm{Ct}$ method, we performed a two-step RT-PCR to obtain cDNA and carried out real-time quantitation using the target gene expression assays and Taqman Universal Master mix (Applied Biosystems).

SW1116 cancer cells $\left(2.5 \times 10^{5}\right.$ cells $\left./ \mathrm{ml}\right)$ were plated in 24-well plates and incubated in a non- $\mathrm{CO}_{2}$ incubator for $18 \mathrm{~h}$. The cells were then treated with APC $(3.4 \mu \mathrm{M})$, proteasome inhibitors [MG132 (1.5 $\mu \mathrm{M})$, PI-1 (36 nM) or EPM (26 nM)] and APC/PI combinations for $24 \mathrm{~h}$. mRNA was extracted using the nucleospin RNAII ready-to-use system (MachereyNagel), and $200 \mathrm{ng} / \mu \mathrm{l}$ of mRNA was used in the RT reaction. Contaminating DNA was eliminated with DNase-I treatment for $20 \mathrm{~min}$ at $25^{\circ} \mathrm{C}$, followed by heat inactivation for $10 \mathrm{~min}$ at $65^{\circ} \mathrm{C}$ prior to cDNA synthesis using the high capacity cDNA reverse transcription kit (Applied Biosystem) according to the manufacturer's instructions. For each sample, $2.5 \mu \mathrm{l}$ of cDNA and $12.5 \mu \mathrm{l}$ of Taqman Universal Master mix (2X) were used, and the final volume was adjusted to $25 \mu \mathrm{l}$ with nuclease-free water on an optical 96-well reaction plate (Applied Biosystems). Real-time PCR was performed on an ABI 7000 SDS system using ABI Prism's SDS collection software version 1.1 (Applied Biosystems). Real-time PCR conditions followed the protocol given by the manufacturer of the Taqman Universal Master mix: step $1,95^{\circ} \mathrm{C}$ for $10 \mathrm{~min}$; step $2,94^{\circ} \mathrm{C}$ for $15 \mathrm{sec}$; and step $3,60^{\circ} \mathrm{C}$ for $1 \mathrm{~min}$. The samples were analyzed using SDS collection software version 1.1 by setting the baseline between 3 and 15 and the threshold at 0.2 . The amount of target normalized to an endogenous reference and relative to a calibrator (untreated) was determined by $2^{-\Delta \Delta C t}$, and the $\log$ comparative $\mathrm{Ct}$ is presented graphically.

Expression of phospho-JNK1/2,phospho-ERK1/2 andphosphoAkt. The phosphorylated forms of JNK1 and JNK2 at Thr ${ }^{183}$ and $\mathrm{Tyr}^{185}$, the phosphorylated forms of ERK1 at $\mathrm{Thr}^{202}$ and $\mathrm{Tyr}^{204}$ and ERK2 at Thr ${ }^{185}$ and $\mathrm{Tyr}^{187}$ and the phosphorylated Akt at $\mathrm{Thr}^{308}$ were determined in both treated and untreated cancer cell extracts using the following PhosphoDetect ELISA kits: JNK1/2 (pThr ${ }^{183} /$ pTyr $^{185}$ ) (Calbiochem-Novabiochem: CBA007), ERK1/2 (pThr ${ }^{185} /$ pTyr $^{187}$ ) (Calbiochem-Novabiochem: CBA006) and Akt (pThr $\left.{ }^{308}\right)$ (Calbiochem-Novabiochem: CBA004). SW1116 and SW837 cancer cells $\left(2.5 \times 10^{5}\right.$ cells $\left./ \mathrm{ml}\right)$ were plated in 24-well plates and incubated in a non- $\mathrm{CO}_{2}$ incubator for $18 \mathrm{~h}$. The cells were then treated with APC $(3.4 \mu \mathrm{M})$, proteasome inhibitors [MG132 (1.5 $\mu \mathrm{M})$, PI-1 (36 nM) or EPM (26 nM)] and APC/PI combinations for $48 \mathrm{~h}$. The phosphoprotein assays were performed according to the manufacturer's instructions.

Chemosensitization potential of the APC and proteasome inhibitor combinations. The potential of the combined treatments with APC and proteasome inhibitors (MG132, PI-1 or EPM) to sensitize human colorectal cancer cells to standard chemotherapeutic drugs was investigated as previously described (20) with some modifications. Briefly, SW1116 and SW837 cells were plated $\left(27 \times 10^{3}\right.$ cells/well) in 96-well plates at $37^{\circ} \mathrm{C}$ in a non- $\mathrm{CO}_{2}$ incubator. Eighteen hours after starting the culture, the cells were treated for $24 \mathrm{~h}$ with various concentrations of the following: camptothecin, CPT $\left(64 \times 10^{-10}\right.$ - $\left.1 \times 10^{-4} \mathrm{M}\right), 5 \mathrm{FU}\left(41.6 \times 10^{-9}-0.65 \times 10^{-3} \mathrm{M}\right)$, oxaliplatin, OXP $\left(4 \times 10^{-10}-0.06 \times 10^{-4} \mathrm{M}\right)$, doxorubicin, DOX $\left(55 \times 10^{-11}-\right.$ $\left.0.85 \times 10^{-5} \mathrm{M}\right)$, carboplatin, CAP $\left(43.5 \times 10^{-10}-0.86 \times 10^{-4} \mathrm{M}\right)$, cisplatin, CIP $\left(26.88 \times 10^{-9}-0.42 \times 10^{-3} \mathrm{M}\right)$, taxol, TAX $\left(93.44 \times 10^{-10}-1.4 \times 10^{-4} \mathrm{M}\right)$, cyclophosphamide, CPA $\left(14 \times 10^{-9}\right.$ - $\left.0.22 \times 10^{-3} \mathrm{M}\right)$, vincristine, VCR $\left(16 \times 10^{-11}-2.5 \times 10^{-5} \mathrm{M}\right)$, etoposide, $\operatorname{ETP}\left(25.6 \times 10^{-10}-0.4 \times 10^{-4} \mathrm{M}\right)$, ellipticine, ELP $\left(12.8 \times 10^{-10}\right.$ $\left.-0.2 \times 10^{-4} \mathrm{M}\right)$, amsacrine, AMS $\left(80 \times 10^{-11}-1.25 \times 10^{-5} \mathrm{M}\right)$, homoharringtonine, HHG $\left(12.8 \times 10^{-11}-0.2 \times 10^{-5} \mathrm{M}\right)$, or aphidicolin, APD $\left(17.28 \times 10^{-11}-0.27 \times 10^{-5} \mathrm{M}\right)$. The drug was then removed, and the cells were washed with HBSS and treated with combinations of APC (62 nM)/MG132 $(0.25 \mu \mathrm{M})$, APC $(240 \mathrm{nM}) /$ MG132 (0.16 $\mu \mathrm{M})$, APC (96 nM)/PI-1 (10 nM), APC (48 nM)/ PI-1 (7.8 nM), APC (250 nM)/EPM (1.4 nM) and APC $(125 \mathrm{nM}) / \mathrm{EPM}(2.8 \mathrm{nM})$ for $72 \mathrm{~h}$. Cell growth was monitored by MTT assay.

Interaction of APC/proteasome inhibitors and standard chemotherapeutic drugs in colorectal cancer cells. To evaluate the type of interaction between the combined treatment with 
A
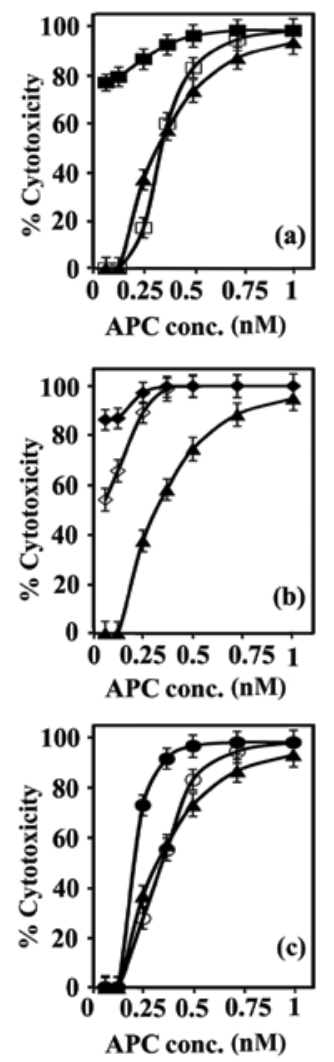

SW837

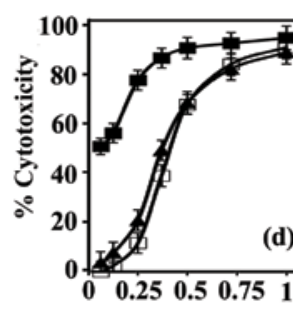

APC conc. (nM)

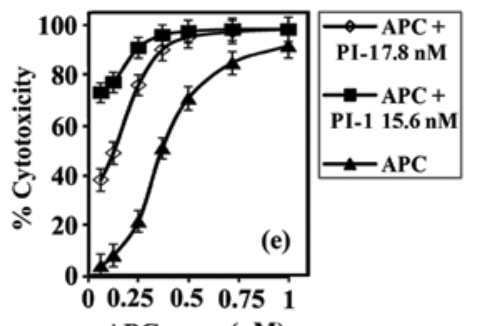

APC conc. (nM)

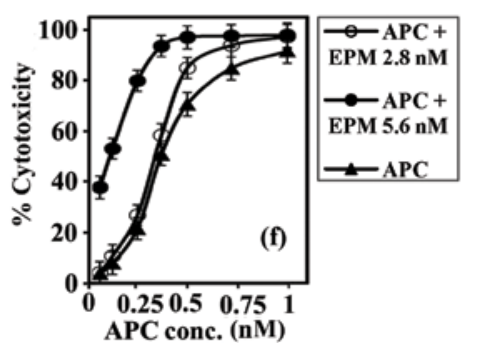

d)

$\simeq$ APC
C
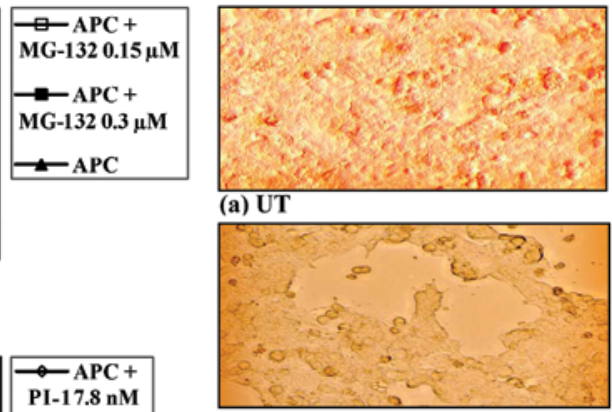

(b) APC

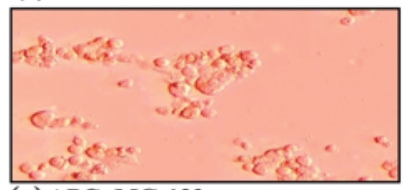

(c) APC+MG-132

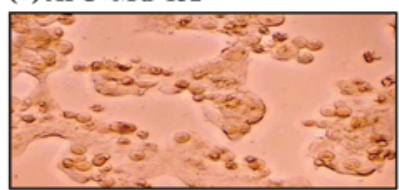

(d) APC+PI-1

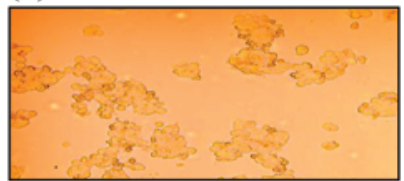

(e) APC+EPM

B

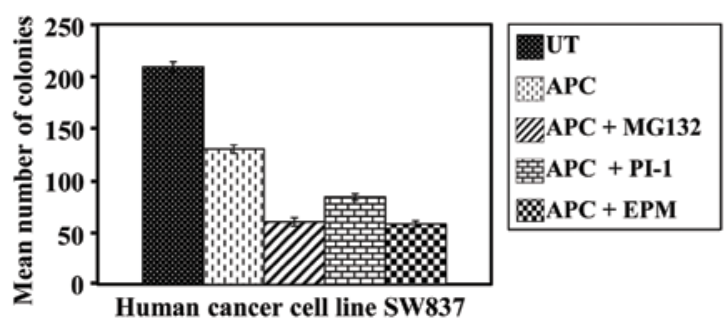

Figure 1. Proteasome inhibitors enhance the antimitogenic effect of APC on human colorectal cancer cells. (A) Inhibition of cancer cell growth. SW1116 (a-c) and SW837 (d-f) colorectal cancer cell lines were treated with various concentrations of APC for $24 \mathrm{~h}$ followed by proteasome inhibitor treatment for $72 \mathrm{~h}$ Control cells were treated with vehicle. Cell growth was monitored by MTT assay. (B) Inhibition of colony formation. Untreated and treated cancer cells were trypsinized, counted and plated $(500 \mathrm{cell} / \mathrm{s} / \mathrm{ml})$ in six-well plates. Following 10-14 days of incubation, the cells were fixed and stained with crystal violet. The stained colonies were counted and compared with the untreated control. (C) Morphological changes of colorectal cancer cells treated with APC, PIs and APC/PI combinations.

APC/MG132, PI-1 or EPM and standard chemotherapeutic drugs in human colorectal cancer cells, the cells were treated as described above with APC/MG132, PI-1 or EPM and standard chemotherapeutic drugs individually and in combination. The type of drug interaction was determined as previously described (21) using the following formulae: $\mathrm{SF}_{\mathrm{A}+\mathrm{B}}>\left(\mathrm{SF}_{\mathrm{A}}\right)$ $\mathrm{x}\left(\mathrm{SF}_{\mathrm{B}}\right)=$ antagonistic, $\mathrm{SF}_{\mathrm{A}+\mathrm{B}}=\left(\mathrm{SF}_{\mathrm{A}}\right) \mathrm{x}\left(\mathrm{SF}_{\mathrm{B}}\right)=$ additive and $\mathrm{SF}_{\mathrm{A}+\mathrm{B}}<\left(\mathrm{SF}_{\mathrm{A}}\right) \times\left(\mathrm{SF}_{\mathrm{B}}\right)=$ synergistic, where $\mathrm{SF}$ is the surviving fraction, $\mathrm{A}$ and $\mathrm{B}$ indicate the agent used alone, and $(\mathrm{A}+\mathrm{B})$ refers to the agents used in combination.

Statistical analyses. Statistical analyses were performed with SPSS-19 software. The results are expressed as the mean \pm SEM. The statistical significance of the differences between control and treated groups were determined by one-way ANOVA. $\mathrm{P}$-values $<0.05$ were considered statistically significant.

\section{Results}

Augmentation of HDACI (APC)-mediated lethality by its combination with proteasome inhibitors. To determine the effect that the combined exposure to APC and PIs would have on human colorectal cancer cells and whether proteasome inhibitors could increase APC lethality, the cancer cells were treated with various concentrations of APC $(0.06-1.0 \mu \mathrm{M})$ in the presence and absence of the following tested proteasome inhibitors: MG132 $(0.16,0.3 \mu \mathrm{M})$, PI-1 (7.8, $15.6 \mathrm{~nm})$, and EPM (1.4, $2.8 \mathrm{nM})$. These concentrations were determined by a dose response study (data not shown). The combined treatment of APC (0.06-1.0 $\mu \mathrm{M})$ with MG132 $(0.16 \mu \mathrm{M})$ produced a growth inhibition of $\mathrm{IC}_{50}=0.34 \mu \mathrm{M}(\mathrm{P} \leq 0.0 .882)$ in SW1116 cells (Fig. $1 \mathrm{Aa})$ and $\mathrm{IC}_{50}=0.35 \mu \mathrm{M}(\mathrm{P} \leq 0.649)$ in SW837 cells (Fig. 1Ad). These values were similar to those 
produced by a single treatment with APC. MG132 $(0.16 \mu \mathrm{M})$ did not improve the sensitivity of SW1116 (sensitization ratio, $\mathrm{SR}=0.95)$ or $\mathrm{SW} 837(\mathrm{SR}=0.92)$ cells to APC. However, the combined treatment of APC and MG132 $(0.3 \mu \mathrm{M})$ produced a much higher and more significant growth inhibition of SW1116 cells $\left(\mathrm{IC}_{90}=0.29 \mu \mathrm{M}, \mathrm{P} \leq 0.0001\right)$ (Fig. 1Aa) and a more significant growth inhibition of SW837 cells $\left(\mathrm{IC}_{90}=0.37 \mu \mathrm{M}\right.$, $\mathrm{P} \leq 0.0001$ ) (Fig. 1Ad) when compared with the single treatment with APC $\left(\mathrm{IC}_{90}=0.77 \mu \mathrm{M}\right.$ for SW1116 and $\mathrm{IC}_{90}=0.94 \mu \mathrm{M}$ for SW837 cells). MG132 $(0.3 \mu \mathrm{M})$ increased the sensitivity of both SW1116 ( $\mathrm{SR}=2.64)$ and $\mathrm{SW} 837(\mathrm{SR}=2.5)$ cells to APC.

The combined treatment of APC $(0.06-1.0 \mu \mathrm{M})$ with PI-1 $(7.8 \mathrm{nM})$ produced a much higher and more significant growth inhibition of SW1116 $\left(\mathrm{IC}_{90}=0.28 \mu \mathrm{M}, \mathrm{P} \leq 0.0001\right)($ Fig. $1 \mathrm{Ab})$ and SW837 $\left(\mathrm{IC}_{90}=0.37 \mu \mathrm{M}, \mathrm{P} \leq 0.0001\right)$ (Fig. 1Ae) cells than that produced by the single treatment with APC $\left(\mathrm{IC}_{90}=0.78 \mu \mathrm{M}\right.$ for SW1116 and $\mathrm{IC}_{90}=0.8 \mu \mathrm{M}$ for SW837 cells) (Fig. $1 \mathrm{Ab}, \mathrm{Ae}$ ). PI-1 $(7.8 \mathrm{nM})$ increased the sensitivity of both SW1116 $(\mathrm{SR}=2.8)$ and SW837 ( $\mathrm{SR}=2.15)$ cells to APC. The combined treatment of APC and PI-1 (15.6 nM) showed a much higher and more significant growth inhibition of SW1116 $\left(\mathrm{IC}_{90}=0.16 \mu \mathrm{M}\right.$, $\mathrm{P} \leq 0.0001)$ (Fig. $1 \mathrm{Ab})$ and $\mathrm{SW} 837\left(\mathrm{IC}_{90}=0.24 \mu \mathrm{M}, \mathrm{P} \leq 0.0001\right)$ (Fig. 1Ae) cells when compared with the single treatment with APC. PI-1 $(15.6 \mathrm{nM})$ greatly increased the sensitivity of both SW1116 ( $\mathrm{SR}=4.67)$ and SW837 ( $\mathrm{SR}=3.3)$ cells to APC.

The combined treatment of APC (0.06-1.0 $\mu \mathrm{M})$ with EPM $(2.8 \mathrm{nM})$ demonstrated a slightly higher growth inhibition of SW1116 $\left(\mathrm{IC}_{50}=0.31 \mu \mathrm{M}, \mathrm{P} \leq 0.441\right)$ cells than that demonstrated by the single treatment with APC $\left(\mathrm{IC}_{50}=0.34 \mu \mathrm{M}\right)$ (Fig. 1Ac). On the other hand, the combined treatment with APC and EPM (2.8 nM) showed a slightly higher but insignificant growth inhibition of SW837 $\left(\mathrm{IC}_{50}=0.34 \mu \mathrm{M}, \mathrm{P} \leq 0.447\right)$ (Fig. 1Af) cells when compared with the single treatment with APC $\left(\mathrm{IC}_{50}=0.39 \mu \mathrm{M}\right)$. EPM $(2.8 \mathrm{nM})$ did not improve the sensitivity of SW1116 (SR=1.11) and SW837 (SR=1.10) cells to APC. The combined treatment of APC and EPM $(5.6 \mathrm{nM})$ produced a higher but insignificant growth inhibition of $\mathrm{SW} 1116\left(\mathrm{IC}_{50}=0.18 \mu \mathrm{M}, \mathrm{P} \leq 0.494\right)$ (Fig. 1Ac) cells, whereas this combination markedly inhibited the growth of SW837 $\left(\mathrm{IC}_{50}=0.11 \mu \mathrm{M}, \mathrm{P} \leq 0.0001\right)$ (Fig. 1Af) cells, when compared with the single treatment with APC. Finally, EPM $(5.6 \mathrm{nM})$ increased the sensitivity of both SW1116 (SR=1.91) and SW837 $(\mathrm{SR}=3.29)$ cells to APC.

Colony formation assays were performed to confirm the results of the inhibition studies. The treatment of SW1116 cells with a combination of APC and MG132 significantly inhibited the colony formation of the cells (mean number of colonies $=60, \mathrm{P} \leq 0.0001$ ) when compared with the untreated SW1116 cells (mean number of colonies $=209$ ). Additionally, this treatment significantly inhibited the colony formation of SW1116 cells $(\mathrm{P} \leq 0.0001)$ when compared with single treatments with either APC (mean number of colonies $=99$ ) or MG132 (mean number of colonies $=108)($ Fig. $1 \mathrm{Ba})$.

The treatment of SW1116 cells with a combination of APC and PI-1 significantly inhibited the colony formation of SW1116 cells (mean number of colonies $=84, \mathrm{P} \leq 0.0001$ ) when compared with the untreated cells (mean number of colonies $=209$ ). Additionally, this treatment significantly inhibited the colony formation of SW1116 cells $(\mathrm{P} \leq 0.0001)$ when compared with the single treatment with PI-1 (mean number of colonies $=130$ ). However, the difference when this combination was compared with the colonies formed upon APC treatment alone was statistically insignificant $(\mathrm{P} \leq 0.061)$ (Fig. 1Bb).

The treatment of SW1116 cells with the combination of APC and EPM significantly inhibited the colony formation of SW1116 cells (mean number of colonies $=58, \mathrm{P} \leq 0.0001$ ) when compared with the untreated SW1116 cells (mean number of colonies $=209$ ). Similarly, this combination significantly inhibited the colony formation of SW1116 cells $(\mathrm{P} \leq 0.0001)$ when compared with single treatments with either APC (mean number of colonies $=99$ ) or EPM (mean number of colonies $=141)($ Fig. 1Bc).

Inhibition of HDACs, the $26 \mathrm{~S}$ proteasome and $\mathrm{NF}-\kappa \mathrm{B}$ binding to DNA and generation of ROS in cancer cells. HDAC activity was measured in the nuclear fractions of untreated and APC-treated colorectal cancer cells to determine whether the antimitogenic activity of APC was associated with the inhibition of intra-nuclear HDAC activity. SW1116 cancer cells treated with APC showed a significant inhibition of HDAC activity $(\mathrm{P} \leq 0.0001)$ when compared with untreated cancer cells (Fig. 2A). To determine whether APC activated the DNA binding activity of NF- $\mathrm{\kappa B}$ and whether the tested proteasome inhibitors could interrupt this activity, the cancer cells were treated with APC, tested proteasome inhibitors and their combinations. The DNA binding activities were monitored in untreated and treated cell extracts.

APC significantly increased the DNA binding activity of NF- $\kappa B$ when compared with untreated cancer cells $(\mathrm{P} \leq 0.022)$. In contrast, this activity was decreased after treatment with MG132 ( $\mathrm{P} \leq 0.87), \mathrm{PI}-1(\mathrm{P} \leq 0.419)$ and EPM $(\mathrm{P} \leq 0.352)$ when compared with the untreated cancer cells; however, this decrease was insignificant. A significant decrease in the DNA binding activity of NF- $\mathrm{KB}$ was observed after the combined treatment with APC/MG132 (P $\leq 0.008)$, APC/PI-1 ( $\mathrm{P} \leq 0.01)$, and $\mathrm{APC} / \mathrm{EPM}(\mathrm{P} \leq 0.001)$ when compared with untreated cancer cells. These findings raise the possibility that the interaction between APC and PIs reflects the inactivation of the cytoprotective NF- $\kappa$ B signaling pathway (Fig. 2B).

$26 \mathrm{~S}$ proteasome activity was also determined in untreated and proteasome inhibitor-treated cancer cell extracts to establish whether the antimitogenic activities of the tested proteasome inhibitors were linked to the inhibition of intracellular proteasome activity. The MG132 ( $\mathrm{P} \leq 0.001)$, PI-1 $(\mathrm{P} \leq 0.001)$ and EPM $(\mathrm{P} \leq 0.0001)$ proteasome inhibitors exhibited significant inhibition of 26S proteasome activity in SW1116 colorectal cancer cells when compared with untreated cancer cells (Fig. 2C). Additionally, treatment with APC $(\mathrm{P} \leq 0.001)$ and the combinations of APC/MG132, APC/PI-1 or APC/EPM significantly inhibited the proteasome activity of colorectal cancer cells $(\mathrm{P} \leq 0.0001)$ when compared with untreated cancer cells (Fig. 2C).

Reactive oxygen species (ROS) have been implicated in HDAC and proteasome inhibitor-induced cytotoxicity in a number of malignancies. Thus, the effects of APC, the tested proteasome inhibitors, and APC/PI combinations on ROS generation were examined in SW1116 cells. ROS levels were markedly increased $(\mathrm{P} \leq 0.0001)$ following the combined treatment with APC/MG132, APC/EPM and APC/PI-1 when 


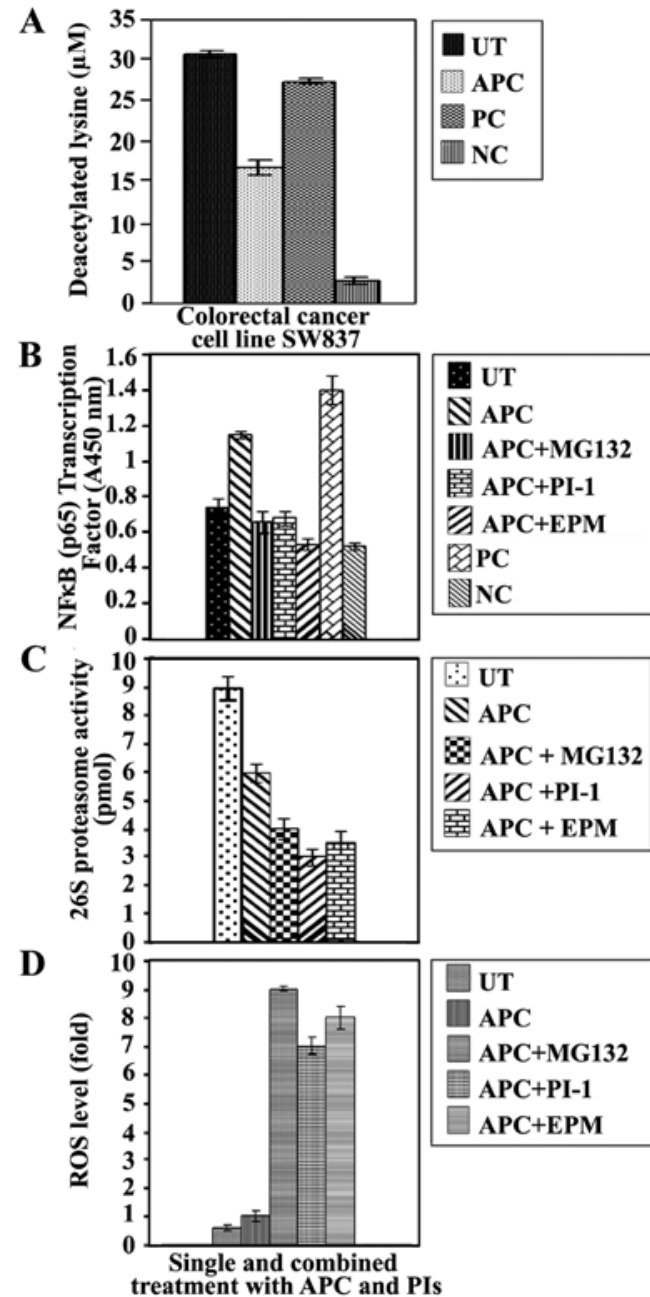

Figure 2. Histone deacetylase, proteasome and NFKB activities and ROS generation in SW1116 colorectal cancer cell extracts. (A) HDAC activity, (B) 26S proteasome activity, (C) NF- $\mathrm{kB}$ binding to DNA, and (D) ROS generation in cancer cells treated with APC, PIs and/or APC/PI combinations.

compared with untreated cells and single treatments with APC and the tested proteasome inhibitors (Fig. 2D). Additionally, single treatments with MG132 ( $\mathrm{P} \leq 0.0001)$, EPM $(\mathrm{P} \leq 0.0001)$ or PI-1 (P $\leq 0.004)$ induced significant ROS when compared with untreated cancer cells (Fig. 2D). The induction of ROS was abrogated by pretreatment with L-NAC (data not shown).

Cell cycle perturbation and induction of apoptosis in cancer cells treated with $A P C$, proteasome inhibitors and APC/PI combinations. To study the effects of APC, the tested PIs, and APC/PI combinations on cell cycle perturbation, the distribution of cancer cells in the various cell cycle phases $\left(\mathrm{G}_{0} / \mathrm{G}_{1}, \mathrm{~S}\right.$, and $\mathrm{G}_{2} / \mathrm{M}$ ) was examined by flow cytometry. Treatment of SW1116 cells with APC resulted in the accumulation of cancer cells in S-phase (57.3 vs. $41.5 \%$ for UT) and a strong decrease in cells in the $\mathrm{G}_{1} / \mathrm{G}_{0}$ phase (33.2 vs. $40.3 \%$ for UT) and $\mathrm{G}_{2} / \mathrm{M}$ phase (9.3 vs. $18 \%$ for UT) (Fig. 3A).

Single treatment with the tested proteasome inhibitors (MG132, PI-1 and EPM) gave results consistent with those recently reported by Abaza et al (22). Treatment of SW1116 cells with MG132 resulted in a marked accumulation of the cancer cells in S-phase (57 vs. $25.5 \%$ for UT) and a decrease in cells in the $\mathrm{G}_{1} / \mathrm{G}_{0}$ phase ( 25.5 vs. $40.3 \%$ for UT) and $\mathrm{G}_{2} / \mathrm{M}$ phase (17.4 vs. $18 \%$ for UT) (22). The combined treatment of APC with G132 arrested the cancer cells in the $\mathrm{G}_{1} / \mathrm{G}_{0}$ phase (51.4 vs. $40.3 \%$ for UT) and S-phase (44.9 vs. $41.5 \%$ for UT), and there was a decrease in the $\mathrm{G}_{2} / \mathrm{M}$ phase $(3.5 \%$ vs. $18 \%$ for UT). The combined treatment of APC and MG132 markedly induced apoptosis as evident from the percentage of cells in $\mathrm{SubG}_{1}(21.2 \%)$ when compared with $\mathrm{UT}\left(\mathrm{SubG}_{1}=0\right)$ and single

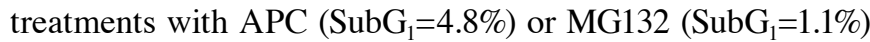
(Fig. 3A).

The treatment of SW1116 cells with PI-1 resulted in the accumulation of cancer cells in the $\mathrm{G}_{1}-\mathrm{G}_{0}$ phase (49.3 vs. $40.5 \%$ for UT) and a decrease in cells in the S-phase (33.2 vs. $41.5 \%$ for UT) and $\mathrm{G}_{2}-\mathrm{M}$ phase (17.3 vs. $18 \%$ for UT) (22). The treatment with a combination of APC and PI-1 resulted in the accumulation of SW1116 cells in the S-phase (52.5 vs. $41.5 \%$ for UT) and $\mathrm{G}_{2} / \mathrm{M}$ phase (23.4 vs. $18 \%$ for UT) and a decrease in cells in the $\mathrm{G}_{1} / \mathrm{G}_{0}$-phase ( 24 vs. $40.3 \%$ for UT). The combined treatment of APC and PI-1 induced apoptosis $\left(\mathrm{SubG}_{1}=8 \%\right)$ when compared with the single treatment with PI-1 $\left(\mathrm{SubG}_{0}=0.2 \%\right)$ or APC $\left(\mathrm{SubG}_{1}=4.8 \%\right)$ (Fig. 3A).

Treatment of SW1116 cancer cells with EPM resulted in the accumulation of cancer cells in the S-phase (51.2 vs. $41.5 \%$ for UT) and a decrease in cells in the $\mathrm{G}_{1} / \mathrm{G}_{0}$-phase ( $31.3 \mathrm{vs}$. $40.3 \%$ for UT) and $\mathrm{G}_{2} / \mathrm{M}$-phase (17.3 vs. $18 \%$ for UT) (22). The combined treatment of APC and EPM also resulted in the accumulation of cancer cells in the S-phase (55.7 vs. $41.5 \%$ for UT) and a decrease in cells in the $\mathrm{G}_{1} / \mathrm{G}_{0}$-phase (33.9 vs. $40.3 \%$ for UT) and the $\mathrm{G}_{2} / \mathrm{M}$-phase ( 10.3 vs. $18 \%$ for UT). The combined treatment increased apoptosis $\left(\mathrm{SubG}_{1}=6 \%\right)$ when compared with the single treatment with APC (4.8\%) (Fig. 3A). In a parallel study, the cell cycle phase distribution of SW837 cells treated with APC, the tested proteasome inhibitors, and APC/PI combinations gave similar results to those obtained with SW1116 cells (data not shown).

The increase in the percentage of SW1116 cells in sub- $G_{1}$ after treatment with combinations of APC and proteasome inhibitors compared with untreated SW1116 cells or SW1116 cells treated with either APC or proteasome inhibitor alone indicates an increase in the percentage of apoptotic cells (Fig. 3A). To determine the effect of PIs (MG132, PI-1 and EPM) on the apoptotic response of the colorectal cancer cells to APC, untreated and treated cancer cells were double-stained with Annexin $\mathrm{V}$ and propidium iodide to distinguish between the different types of cell death and analyzed by flow cytometry. Annexin V binding combined with PI labeling was performed to distinguish between early apoptotic (Annexin $\mathrm{V}^{+} /$propidium iodide ${ }^{-}$) and necrotic (Annexin $\mathrm{V}^{+} /$propidium iodide ${ }^{+}$) cells

Treatment of SW1116 cells with the combination of APC and EPM markedly induced apoptosis in the cancer cells ( $0.1 \%$ early apoptosis, $43.2 \%$ late apoptosis and $0.7 \%$ necrosis) when compared with untreated SW1116 cells $(0.0 \%$ early apoptosis, $4.7 \%$ late apoptosis and $0.4 \%$ necrosis), SW1116 cells treated with APC ( $0.0 \%$ early apoptosis, $26.4 \%$ late apoptosis and $0.8 \%$ necrosis) (Fig. 3B), or SW1116 cells treated with EPM (0.1\% early apoptosis, $20.3 \%$ late apoptosis and 3.1\% necrosis) (22).

In addition, the combination of APC and MG132 greatly induced the apoptosis of SW1116 cells (0.3\% early apoptosis, $67.7 \%$ late apoptosis, and $9.9 \%$ necrosis) when compared with untreated SW1116 cells ( $0.0 \%$ early apoptosis, $4.7 \%$ late 


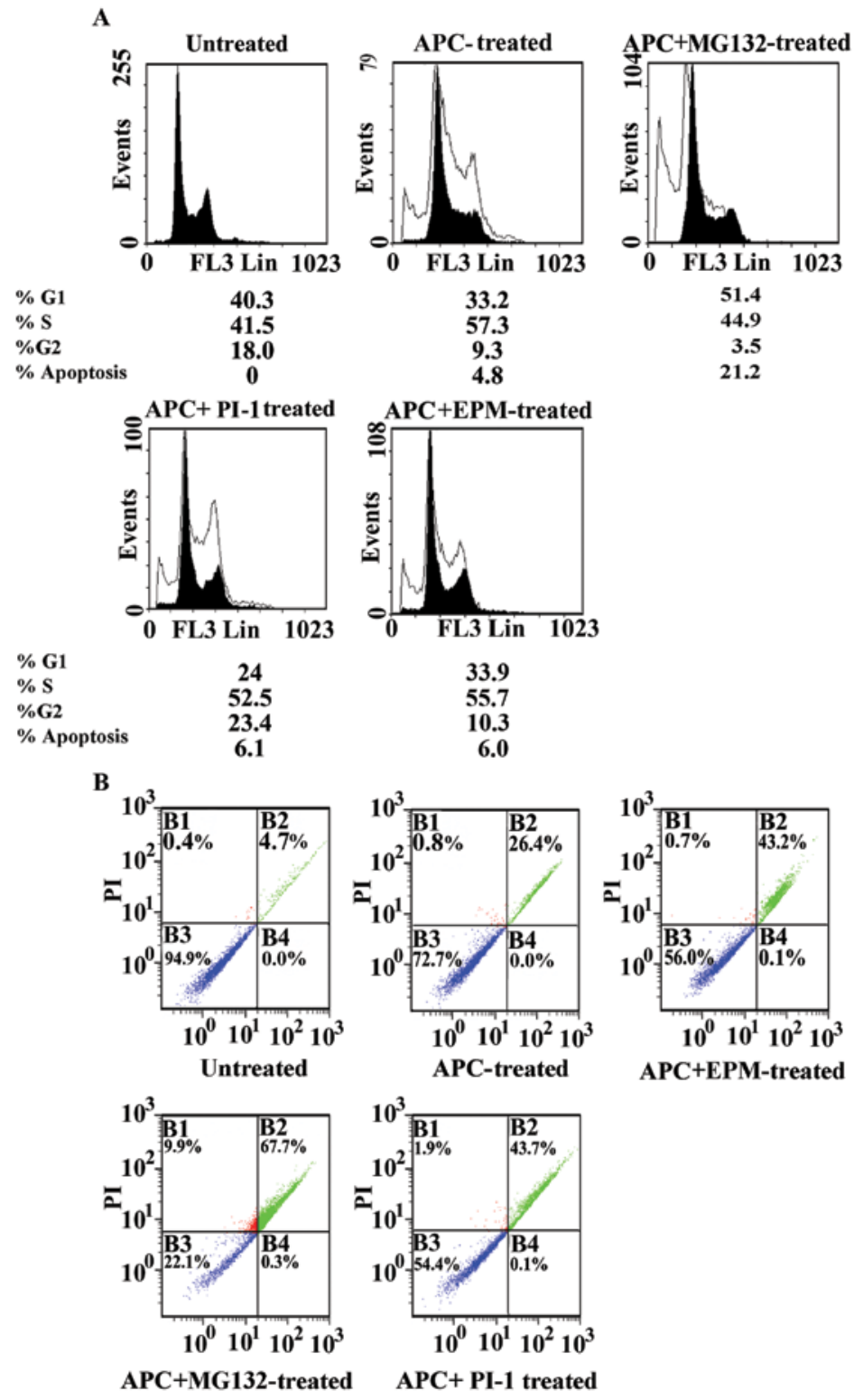

Figure 3. Flow cytometric analysis of cell cycle distribution and induction of apoptosis in colorectal cancer cells treated with APC, proteasome inhibitors and APC/PI combinations. (A) Flow cytometric analysis of cell cycle phases. At least three samples were analyzed, and 20,000 events were scored. The vertical axis represents the relative number of events, and the horizontal axis represents the fluorescence intensity. (B) Induction of apoptosis. (B1) percentage of necrotic cells, (B2) percentage of late apoptotic cells, (B3) percentage of living cells, and (B4) percentage of early apoptotic cells.

apoptosis, and $0.4 \%$ necrosis), SW1116 cells treated with APC ( $0.0 \%$ early apoptosis, $26.4 \%$ late apoptosis, and $0.8 \%$ necrosis) (Fig. 3B), or SW1116 cells treated with MG132 (0.0\% early apoptosis, $26.4 \%$ late apoptosis, and $0.8 \%$ late apoptosis) (22).

The combination of APC and PI-1 also induced the apoptosis of SW1116 cells (0.1\% early apoptosis, $43.7 \%$ late apoptosis, and $1.9 \%$ necrosis) when compared with untreated SW1116 cells $(0.0 \%$ early apoptosis, $4.7 \%$ late apoptosis, and $0.4 \%$ necrosis), SW1116 cells treated with APC (0.0\% early apoptosis, $26.4 \%$ late apoptosis, and $0.8 \%$ necrosis) (Fig. 3B) or PI-1-treated SW1116 cells (0.0\% early apoptosis, $11.9 \%$ late apoptosis, and $0.8 \%$ necrosis) (22). These results suggest that the tested PIs markedly increased the APC-mediated lethality in human colorectal cancer cells. The induction of apoptosis in SW837 cells treated with APC, the tested proteasome inhibitors, and APC/PI combinations provided similar results to those obtained with SW1116 cells (data not shown).
mRNA expression of cell cycle and apoptosis-related genes in cancer cells treated with APC, proteasome inhibitors and APC/PI combinations. The effects of the combination APC/PI treatment on the expression/activation of various signaling molecules were examined to understand the molecular mechanisms underlying the increase in the APC-mediated lethality in human colorectal cancer cells upon addition of proteasome inhibitors.

The combined treatment of SW1116 cells with APC and MG132, PI-1 or EPM markedly downregulated the mRNA expression of genes related to cell cycle control $(C d k 1, C d k 2$, $C d k 4, C d k 6$ and $C d c 25 A$ ) when compared with the single treatment with APC (Fig. 4) or PIs (MG132, PI-1, EPM) (22). On the other hand, the same combined treatments upregulated the mRNA expression of $p 15, p 19, p 21$ and $p 27$ when compared with the single treatments with APC (Fig. 4A) and the tested PIs (22). 
A mRNA expression of genes controlling cell cycle
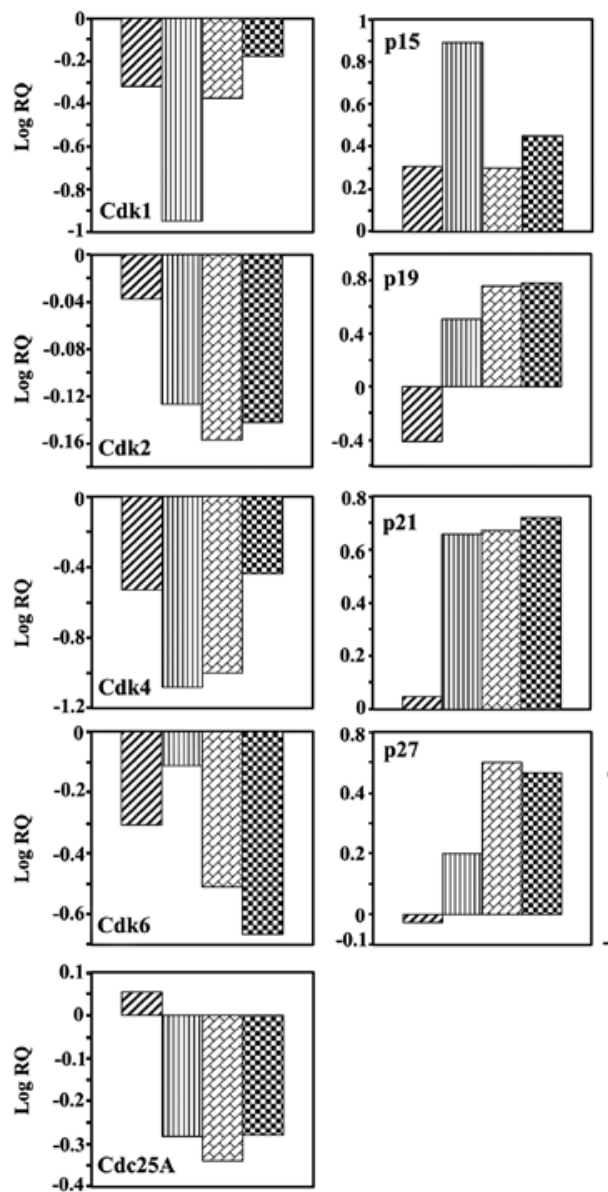

B mRNA expression of genes controlling apoptosis
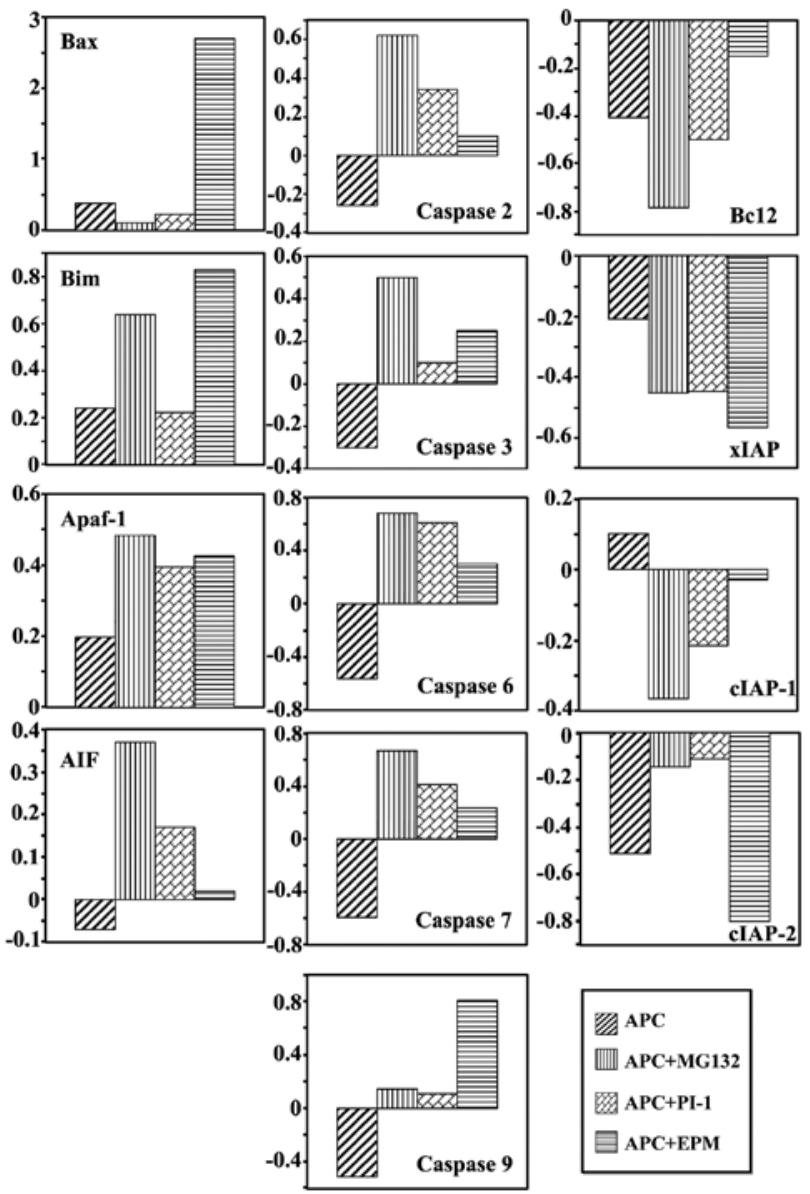

Figure 4. mRNA expression of genes regulating the cell cycle (A) and apoptosis (B) in SW1116 colorectal cancer cells treated with APC, proteasome inhibitors, and APC/PI combinations. The expression of genes controlling the cell cycle and apoptosis was determined by measuring mRNA levels by real-time RT-PCR and using the comparative $\Delta \Delta \mathrm{Ct}$ method to calculate expression changes. The amount of the target was normalized to an endogenous reference and relative to a calibrator and is given by $2^{-\Delta \Delta C t}$.

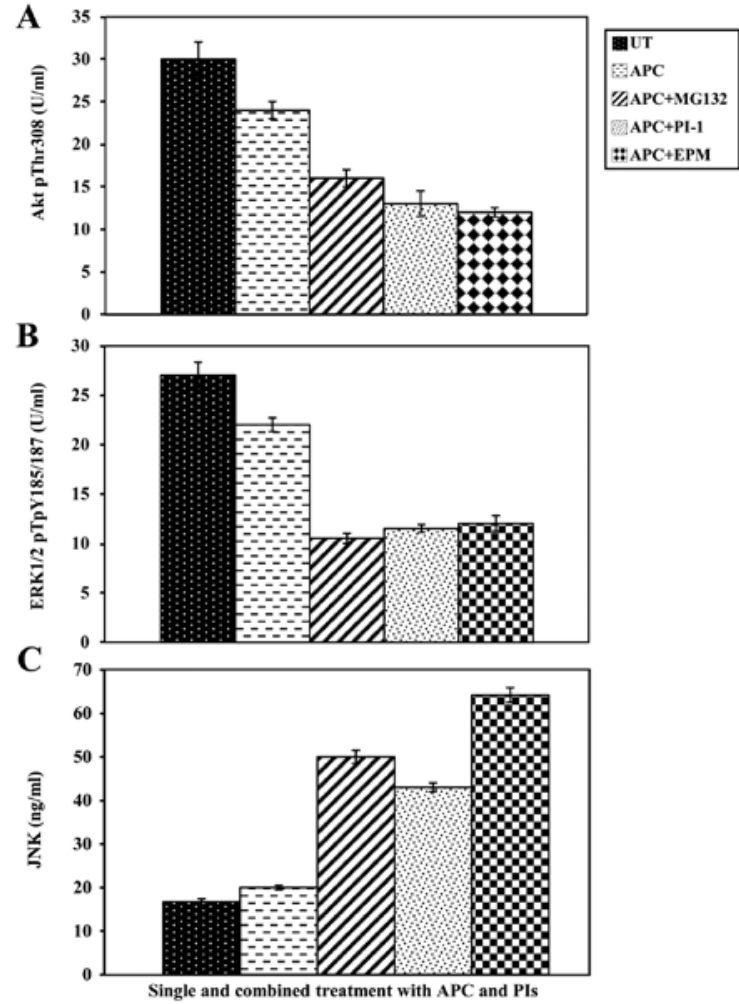

The combined treatment of SW1116 cells with APC and the tested proteasome inhibitors upregulated the mRNA expression of the pro-apoptotic genes, Bax, Bim, apafl and caspases $2,3,6,7$ and 9 . The same combined treatment downregulated the expression of the anti-apoptotic genes, $B c l 2, x-I A P, c-I A P 1$ and $c-I A P 2$ when compared with the single treatment with APC (Fig. 4B) or the tested PIs (MG132, PI-1 and EPM) (22). The cycle threshold $(\mathrm{Ct})$ values of the target genes under investigation in this study were in the range of 20.826-30.981.

To further understand the potential mechanisms of action of APC, proteasome inhibitors and APC/PI combinations, the expression of pAkt, $\mathrm{pERK}$ and $\mathrm{pJNK}$ was evaluated. Treatment

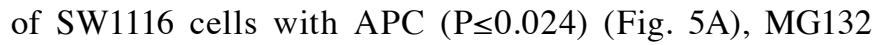
$(\mathrm{P} \leq 0.001)(22)$, or APC/MG132 ( $\mathrm{P} \leq 0.0001)$ (Fig. 5A) resulted in a significant decrease in the levels of pAkt when compared with untreated cancer cells. The combined treatment of APC and MG132 produced a significant decrease in the levels of pAkt when compared with the single treatment with APC

Figure 5. Levels of pAkt, pERK, and pJNK in colorectal cancer cells treated with APC, proteasome inhibitors, and APC/PI combinations. The levels of pAkt (A), pERK (B) and pJNK (C) were determined in treated and untreated SW1116 cell extracts using enzyme immune assays. 
A SW1116, chemosensitization with APC/MG132
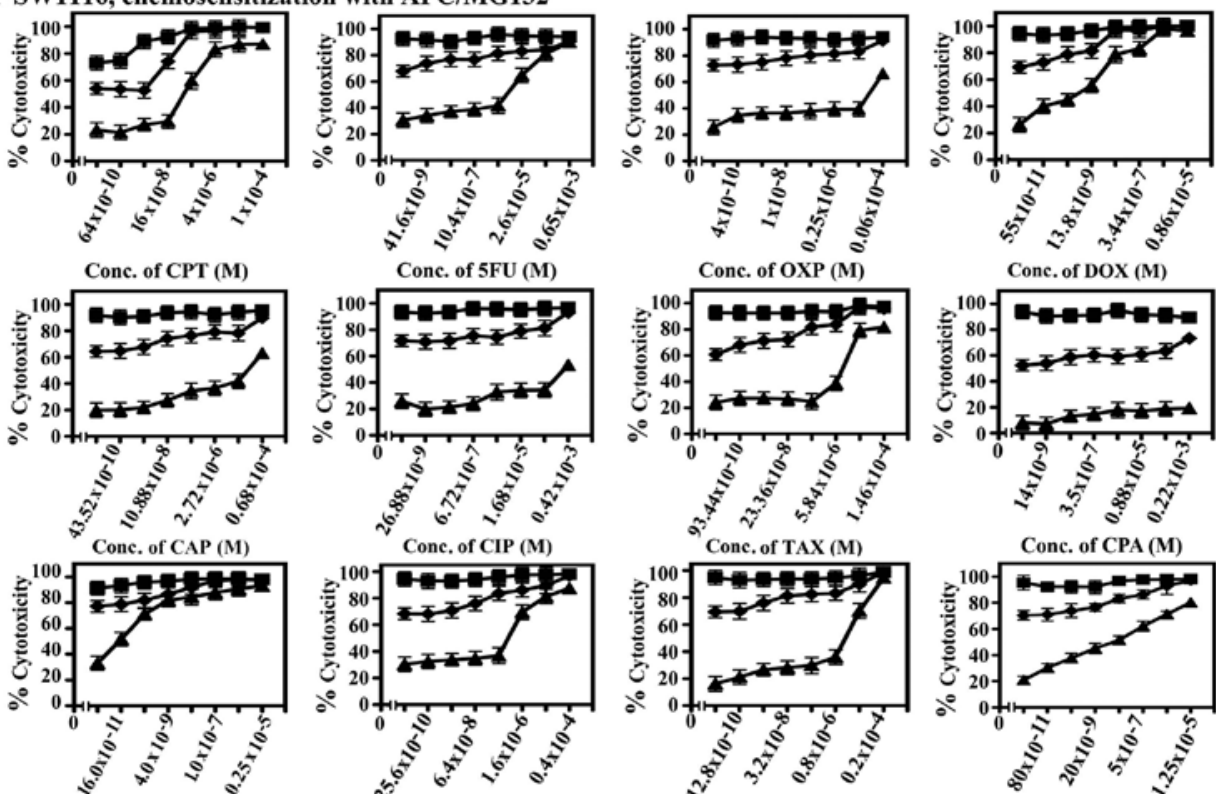

Conc, of CIP (M)
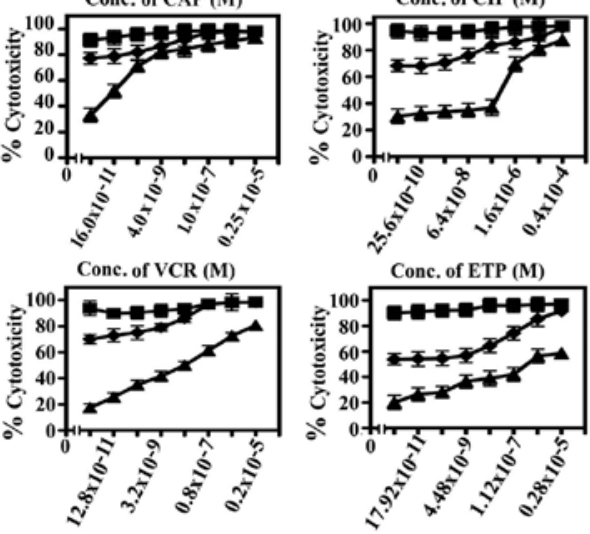

Conc. of HHG (M)

Conc- of APD (M)

B SW1116, chemosensitization with APC/PI-1

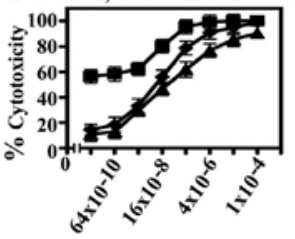

Conc. of CPT (M)

- Drug

- Drug +

$62 \mathrm{nM} \mathrm{APC} / 0.25 \mu \mathrm{M} M G 132$

-Drug +

$240 \mathrm{nM}$ APC/0.16 $\mu \mathrm{M}$ MG132

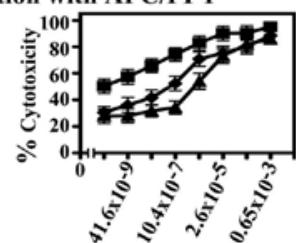

Conc. of $5 F U$ (M)

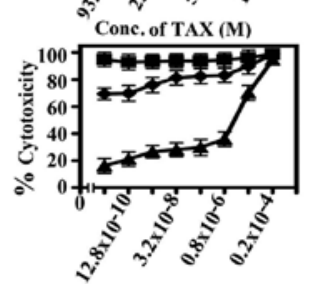

Conc. of ELP (M)
Conc. of AMS (M)

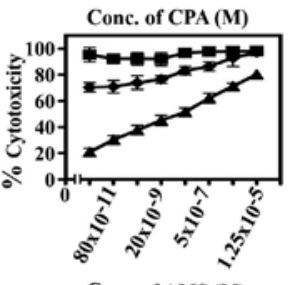

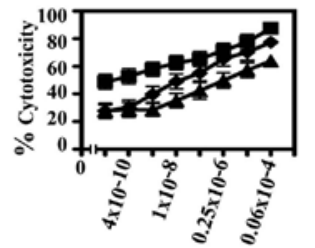

Conc. of OXP (M)

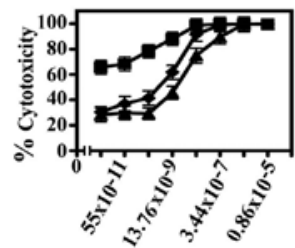

Conc. of DOX (M)

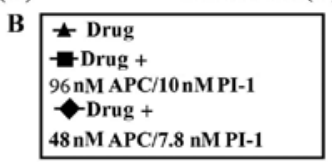

Figure 6. Chemosensitization of SW1116 colorectal cancer cells by combined treatment with APC and MG132 or PI-1. SW1116 cells were plated in 96-well plates for $18 \mathrm{~h}$ followed by incubation with various concentrations of CPT, 5FU, OXP, DOX, CAP, CIP, TAX, CPA, VCR, ETP, ELP, AMS, HHG and APD for $24 \mathrm{~h}$. The drugs were then removed, and the cells were washed with HBSS and treated with a combination of APC (240 nM)/MG132 (0.16 nM) and APC $(62 \mathrm{nM}) / \mathrm{MG} 132(0.25 \mathrm{nM})(\mathrm{A})$ or APC $(96 \mathrm{nM}) / \mathrm{PI}-1(10 \mathrm{nM})$ and APC $(48 \mathrm{nM}) / \mathrm{PI}-1$ (7.8 nM) (B). Control cells were treated with vehicle (DMSO at a final concentration of $0.2 \%)$. Cell growth was monitored by MTT assay.

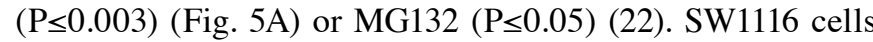

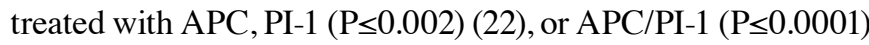
(Fig. 5A) exhibited a significant decrease in the levels of pAkt when compared with untreated cancer cells. The combined treatment with APC/PI-1 significantly reduced the levels of pAkt when compared with the single treatment with either

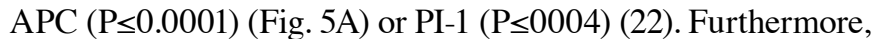
SW1116 cells treated with a combination of APC/EPM showed a significant growth inhibition when compared with untreated cells $(\mathrm{P} \leq 0.0001)$ or cells treated with APC alone $(\mathrm{P} \leq 0.0001)$ (Fig. 5A) and EPM alone $(\mathrm{P} \leq 0.014)(22)$.

SW1116 cells treated with MG132, EPM or PI-1 (23) and combinations (APC/MG132, APC/EPM or APC/PI-1) showed a significant decrease in the levels of pERK1/2 $(\mathrm{P} \leq 0.0001)$ when compared with untreated cancer cells. Additionally, SW1116 cells treated with APC showed a significant decrease in pERK1/2 levels $(\mathrm{P} \leq 0.009)$ when compared with untreated cells (Fig. 5B).

The combined treatment with APC/MG132 produced a significant decrease in the levels of $\mathrm{pERK} 1 / 2$ when compared with the single treatment with either APC $(\mathrm{P} \leq 0.0001)$ or MG132 $(\mathrm{P} \leq 0.0001)$ (22). The expression of pERK1/2 significantly decreased following the combined treatment with APC/PI-1 when compared with the single treatment with APC $(\mathrm{P} \leq 0.0001)$ or PI-1 ( $\mathrm{P} \leq 0.036)$ (22). The combined treatment with APC/EPM also produced a significant decrease in the levels of pERK1/2 when compared with those produced by single treatment with either APC ( $\mathrm{P} \leq 0.0001)$ (Fig. 5B) or EPM ( $\mathrm{P} \leq 0.002)(22)$. 
A SW1116, chemosensitization with APC/PI-1
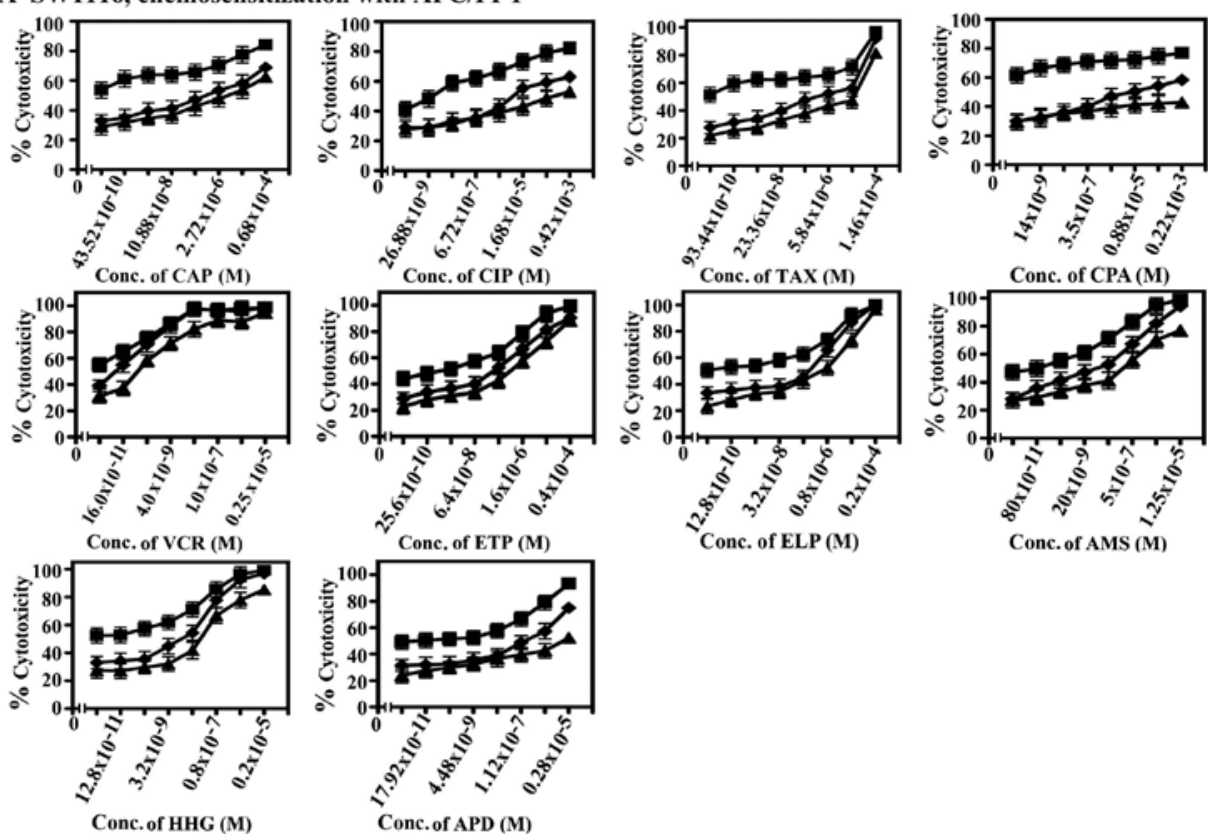

B SW1116, chemosensitization with APC/EPM
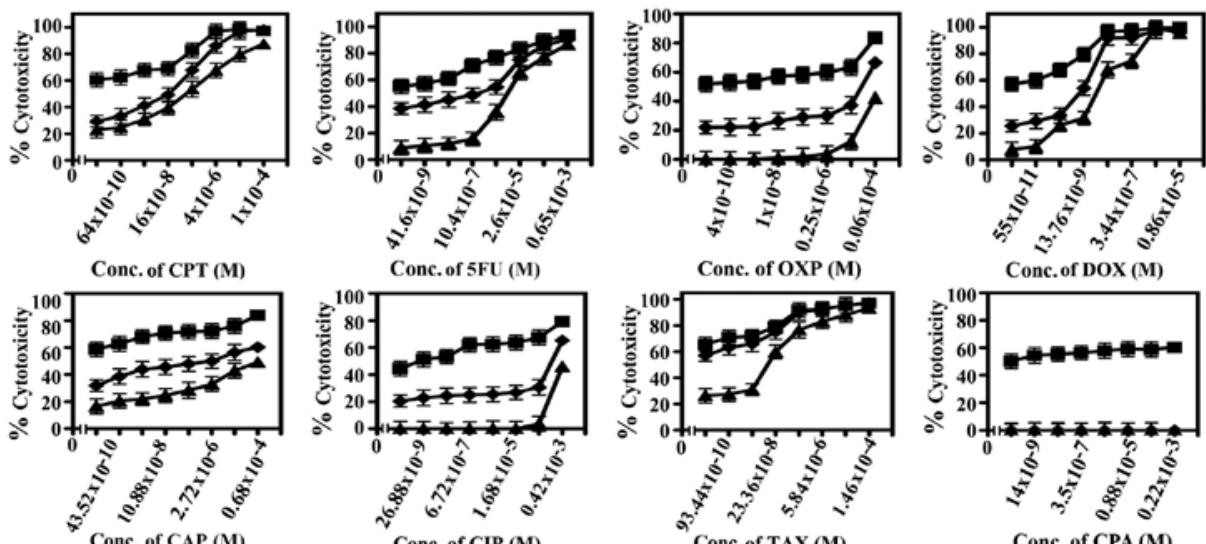

Conc. of $5 F U$ (M)
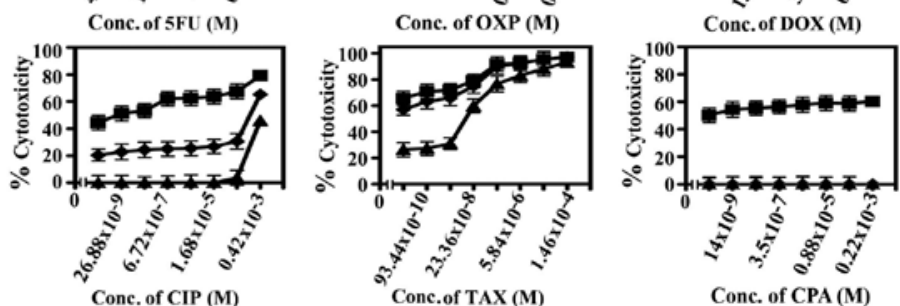

A Drug

- Drug +

96 nM APC / 10 nM PI-

$\checkmark$ Drug +

$48 \mathrm{nM}$ APC/7.8 nM PI-1

Conc.of TAX (M)

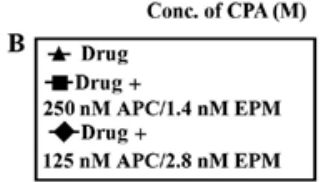

Figure 7. Chemosensitization of SW1116 colorectal cancer cells by combined treatment with APC and PI-1 or EPM. SW1116 cells were plated in 96-well plates for $18 \mathrm{~h}$ followed by incubation with various concentrations of CAP, CIP, TAX, CPA, VCR, ETP, ELP, AMS, HHG and APD (A) or CPT, 5FU, OXP, DOX, CAP, CIP, TAX and CPA (B) for $24 \mathrm{~h}$. The drugs were then removed, and the cells were washed with HBSS. SW1116 cells were treated with a combination of APC (48 nM)/PI-1 (7.8 nM) and APC (96 nM)/PI-1 (10 nM) (A) or APC (125 nM)/EPM (2.8 nM) and APC (250 nM)/EPM (1.4 nM) (B). Control cells were treated with vehicle (DMSO at a final concentration of $0.2 \%$ ). Cell growth was monitored by MTT assay.

SW1116 cells treated with MG132, EPM (22), and the APC/MG132, APC/EPM or APC/PI-1 combinations showed a significant increase in the levels of pJNK $(\mathrm{P} \leq 0.0001)$ when compared with untreated cancer cells. Additionally, the treatment of SW1116 cells with APC or PI-1 resulted in an increase in the expression of pJNK. However, insignificant $(P \leq 0.129)$ and significant $(P \leq 0.002)$ increases in the levels of pJNK were reported following treatment with APC (Fig. 5C) and PI-1 (22), respectively, when compared with untreated cells. In addition, SW1116 cells treated with a combination of APC/MG132, APC/PI-1, and APC/EPM showed a significant increase $(\mathrm{P} \leq 0.0001)$ in the levels of $\mathrm{pJNK}$ when compared with the single treatment with APC (Fig. 5C), MG132, PI-1 or EPM (22).
Chemosensitization of human colorectal cancer cells by combined treatment with APC and proteasome inhibitors. The efficacy of the combined treatment with the HDACI, APC, and the proteasome inhibitors, MG132, PI-1 or EPM, to sensitize cancer cells to standard chemotherapeutic drugs and the type of interaction between the combined treatments and standard chemotherapeutic drugs were investigated. The results are summarized in Figs. 6-10 and Tables I-V.

The combination of APC and the tested PIs strikingly increased the sensitivity of colorectal cancers to ETP

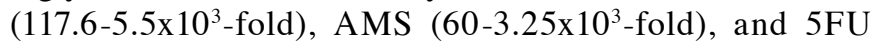
(84-2.76x 104-fold). The combination of APC and MG132 or PI-1 also resulted in marked increases in the sensitivity of colorectal cancer cells to TAX (50-4.48x10 ${ }^{3}$-fold) and HHG (50-133-fold). 
A SW1116, chemosensitization with APC/EPM
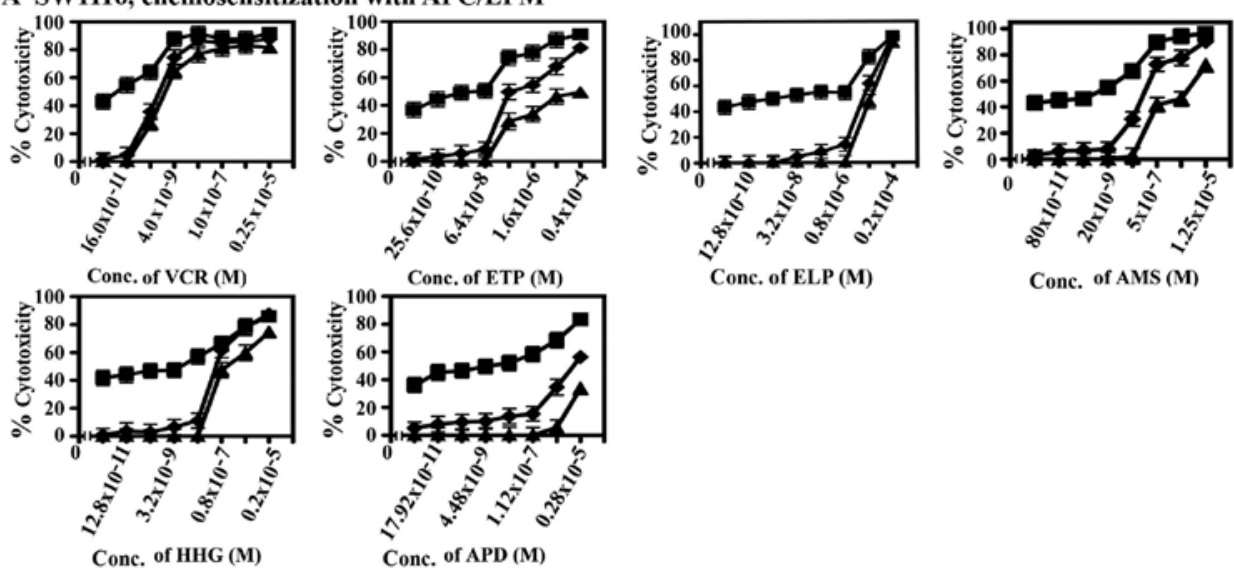

Conc. of ELP (M)

Conc. of AMS (M)

Conc. of HHG (M)

Conc. of APD (M)

B SW 837 chemosensitization with APC/ MG132
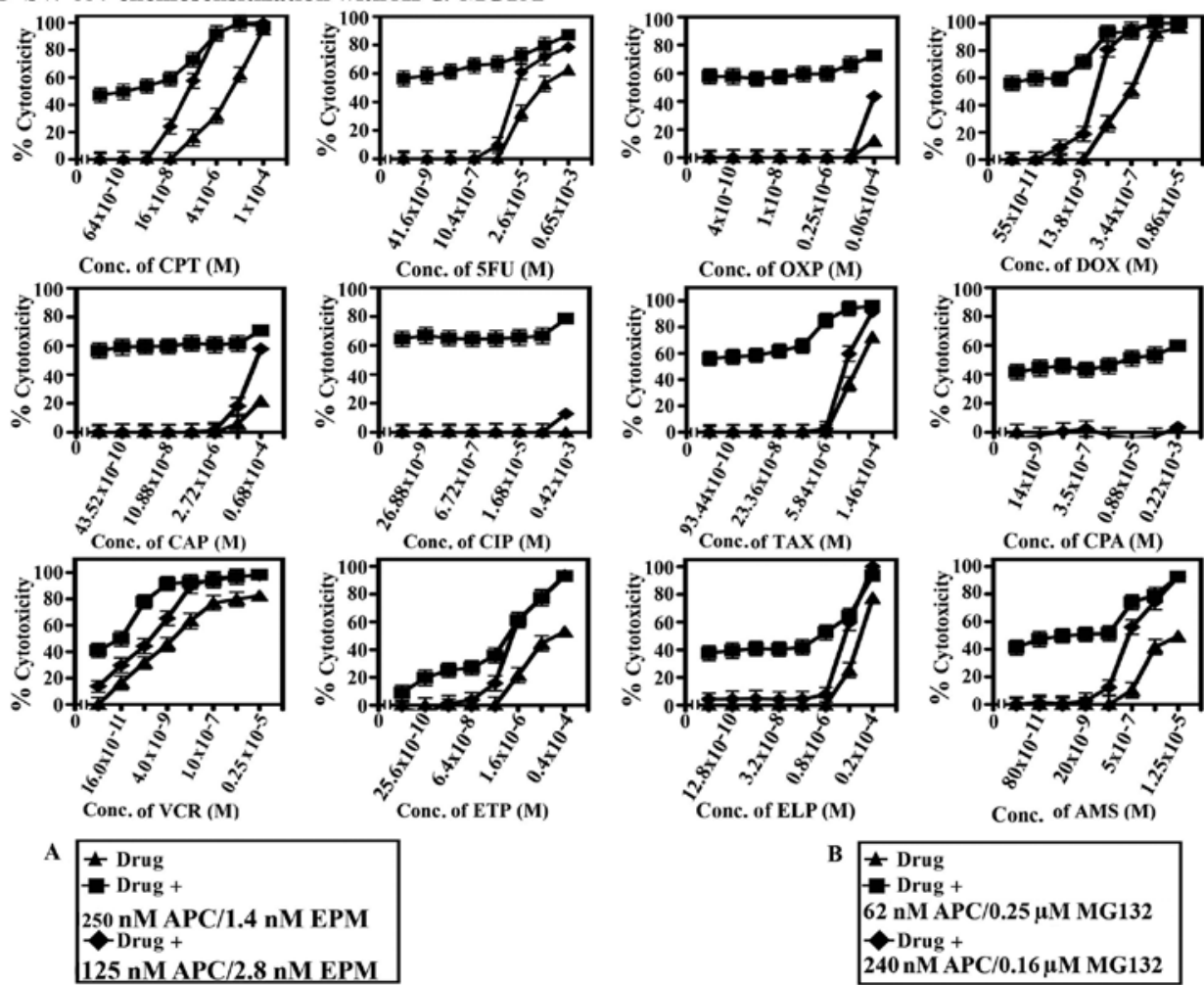

Figure 8. Chemosensitization of the SW1116 and SW837 colorectal cancer cell lines by combined treatment with APC and EPM or MG132. The cells were plated in 96-well plates for $18 \mathrm{~h}$. SW1116 cells were treated with various concentrations of VCR, ETP, ELP, AMS, HHG and APD for 24 h. The drugs were then removed, and the cells were washed with HBSS and treated with a combination of APC (125 nM)/EPM (2.8 nM) or APC (250 nM)/EPM (1.4 nM) (A). The SW837 cells were treated with CPT, 5FU, OXP, DOX, CAP, CIP, TAX, CPA, VCR, ETP, ELP and AMS for 24 h. The drugs were then removed, and the cells were washed with HBSS and treated with a combination of APC (240 nM)/MG132 (0.16 $\mu \mathrm{M})$ or APC (62 nM)/MG132 (0.25 $\mu \mathrm{M})(\mathrm{B})$. Control cells were treated with vehicle (DMSO at a final concentration of $0.2 \%$ ). Cell growth was monitored by MTT assay.

Combining APC with MG132 or EPM increased the sensitivity

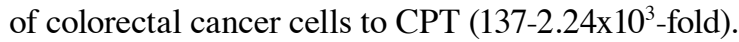

The combination of APC and MG132 showed a 133-fold increase in the sensitivity of the SW1116 colon cancer cells to HHG, whereas the combination of APC and PI-1 increased the sensitivity of SW1116 cells to CIP $\left(1.5 \times 10^{3}\right.$-fold), APD (3.71 $\times 10^{4}$-fold), and TAX $\left(4.48 \times 10^{3}\right.$-fold). Finally, the combination of APC and PI-1 increased the sensitivity of the SW837 rectal cancer cells to AMS $\left(1.73 \times 10^{3}\right.$-fold $)$, whereas the combination of APC and EPM increased the sensitivity of SW837 cells to ETP (5.7x10 2 -fold) and CPT (137-fold).

Collectively, these results clearly indicate the potential of the APC/proteasome inhibitor combination treatments to markedly increase the sensitivity of colorectal cancer cells to standard chemotherapeutic drugs. The data also suggest different mechanisms of action and sensitivity in a combination- and cancer subtype-dependent manner. The synergistic and/or additive interaction between the tested chemotherapeutics and the various combinations of APC and PIs was dependent on the type of drug tested, the combination of APC and PIs, and the polymorphism of the genes encoding the drugmetabolizing enzymes, transporters or drug targets. The effect of the treatment with APC/MG132, APC/PI-1 and APC/EPM on normal human fibroblast cells (CRL1554) was also examined microscopically and by MTT assay. The results shown in Fig. 10B clearly demonstrated that these combinations had 
A SW 837, chemosensitization with APC/MG132
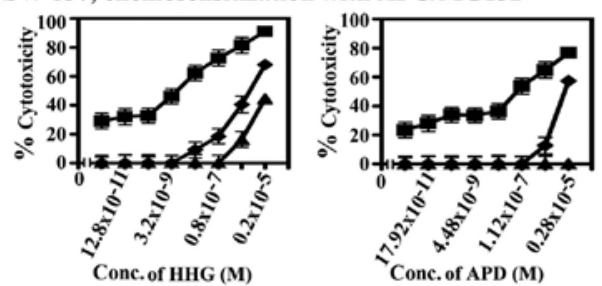

B SW 837, chemosensitization with APC/PI-1
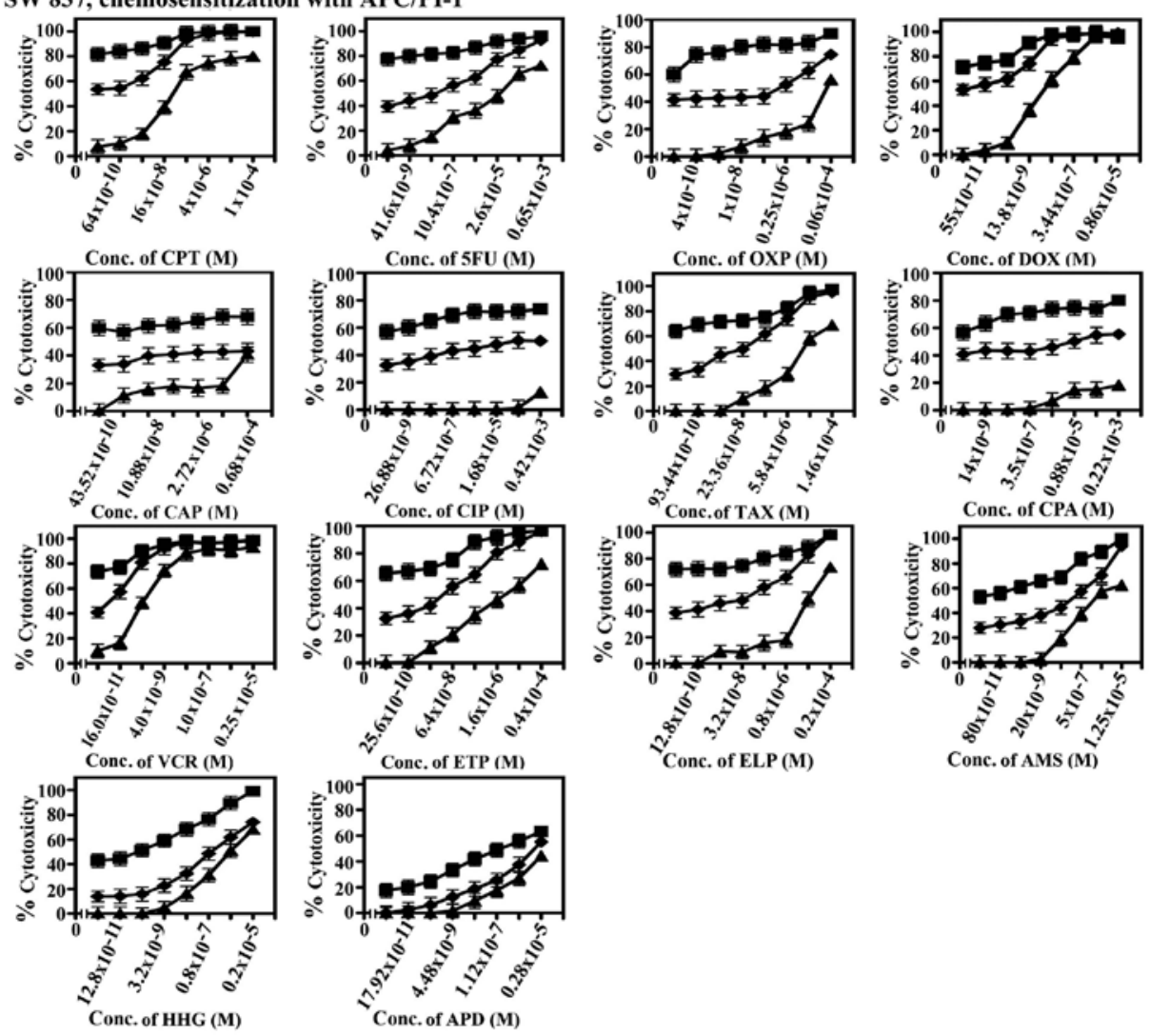

onc. of ELP (M)

Conc. of AMS (M)
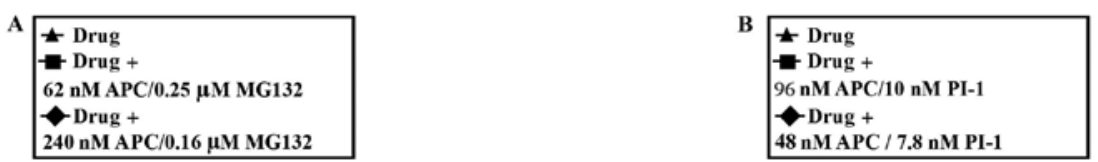

Figure 9. Chemosensitization of the SW837 colorectal cancer cell line by combined treatment with APC and MG132 or PI-1. SW837 cells were plated in 96-well plates for $18 \mathrm{~h}$. After treating the cells with various concentrations of HHG and APD for $24 \mathrm{~h}$, the drugs were removed, and the cells were washed with HBSS and treated with a combination of APC $(240 \mathrm{nM}) /$ MG132 $(0.16 \mu \mathrm{M})$ or APC $(62 \mathrm{nM}) /$ MG132 $(0.25 \mu \mathrm{M})$ for $72 \mathrm{~h}(\mathrm{~A})$. The SW837 cells were treated with various concentrations of CPT, 5FU, OXP, DOX, CAP, CIP, TAX, CPA, VCR, ETP, ELP, AMS, HHD and APD for $24 \mathrm{~h}$. The drugs were then removed, and the cells were washed with HBSS and treated with a combination of APC (48 nM)/PI-1 (7.8 nM) or APC (96 nM)/PI-1 (10 nM) for $72 \mathrm{~h}$ (B). Control cells were treated with vehicle (DMSO at a final concentration of $0.2 \%$ ). Cell growth was monitored by MTT assay.

little effect $(\leq 15 \%)$ on CRL1554 cells, indicating their minimal cytotoxicities.

\section{Discussion}

HDACs have been demonstrated to be associated with oncogenic transformation by promoting the function of transcription factors in certain hematologic malignancies and solid tumors (23). Therefore, HDACIs have emerged as a novel class of anticancer agents for the treatment of solid and hematological malignancies. Despite the promising results indicating the usefulness of employing HDACIs as an epigenetic-targeted therapy, its limited success in specific cancers as a single drug has prompted further investigation of combining HDACIs with other anticancer agents. These combination regimens may enhance the clinical efficacy of HDACIs and provide a therapeutic advantage over HDACIs as a single drug.

Recent evidence has suggested that the transcriptional activation induced by HDACIs requires a mechanism other than chromatin remodeling; such a mechanism is through histone hyperacetylation, a process that is associated with protein kinase signaling pathways or acetylation of non-histone proteins, such as p53 or NF- $\mathrm{BB}(10)$. The NF- $\mathrm{kB}$ signaling pathway is appreciated as one of the pivotal modulators of specific gene expression and differential cellular responses by HDACIs, as the selective inhibition of the NF- $\mathrm{kB}$ pathway leads to an abrogation of NF- $\mathrm{KB}$-dependent gene expression by HDACIs and the unresponsiveness of cells to HDACI-induced 
A SW 837, chemosenitization with APC/EPM
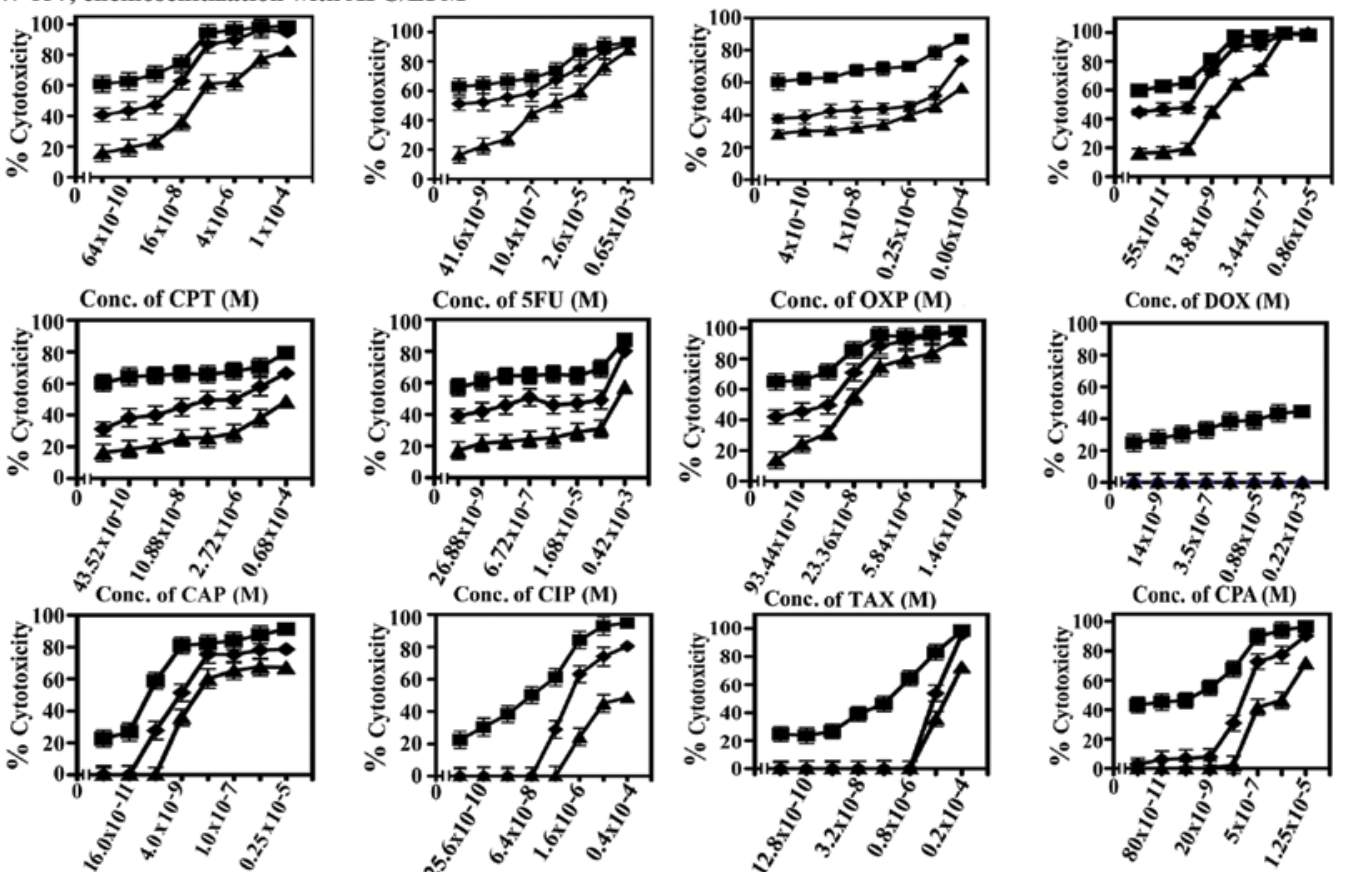

Conc. of VCR (M)
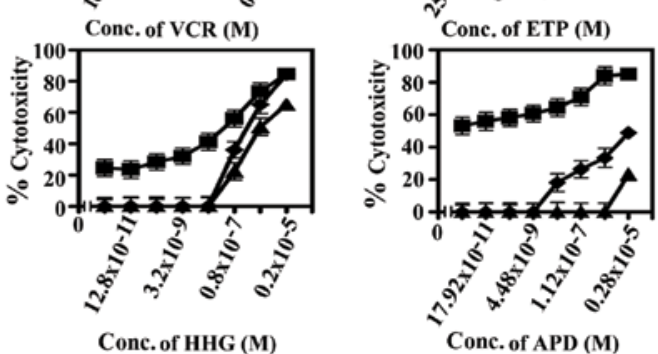

Conc. of ELP (M)

\# Drug
- Drug +
250 nM APC/1.4 nM EPM
125 nM APC /2.8 nM EPM

Conc. of HHG (M)

Conc. of APD (M)

B Effect of the combination of APC/MG132, PI-1 or EPM on CRL1554
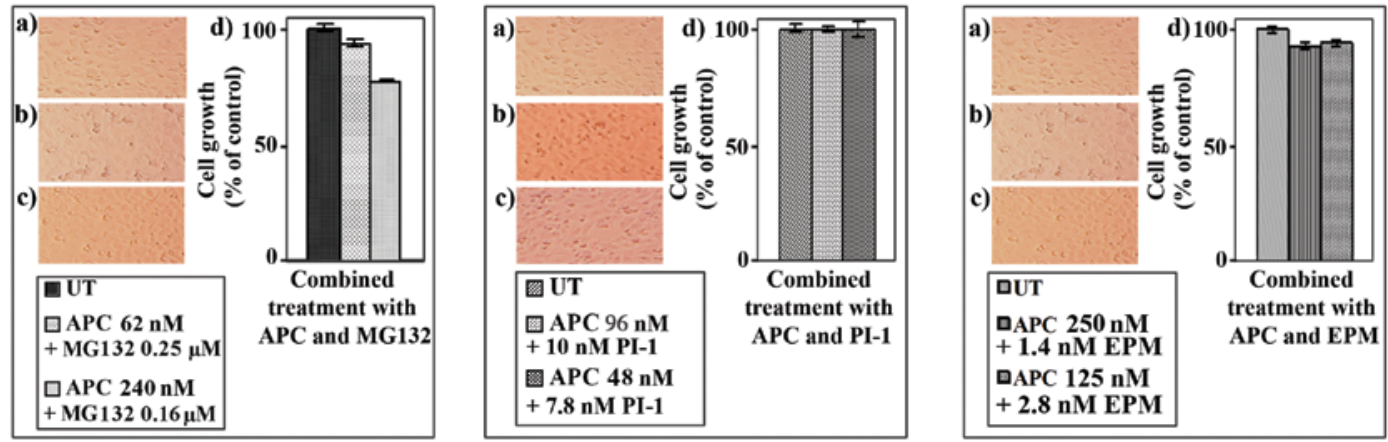

Figure 10. Chemosensitization of the SW837 colorectal cancer cell line upon combined treatment with APC and EPM, and the effect of the combined treatment of APC with PIs on normal human fibroblasts. SW837 cells were plated in 96-well plates for $18 \mathrm{~h}$. The cells were then treated with various concentrations of CPT, 5FU, OXP, DOX, CAP, CIP, TAX, CPA, VCR, ETP, ELP, AMS, HHG, and APD for 24 h. The drugs were removed, and the cells were washed with HBSS and treated with a combination of APC $(125 \mathrm{nM}) / \mathrm{EPM}(2.4 \mathrm{nM})$ or APC $(250 \mathrm{nM}) / \mathrm{EPM}(1.4 \mathrm{nM})$ for $72 \mathrm{~h}(\mathrm{~A})$. The effect of the combined treatment with APC $(62 \mathrm{nM}) / \mathrm{MG} 132(0.25 \mu \mathrm{M})$, APC $(240 \mathrm{nM}) / \mathrm{MG} 132(0.16 \mu \mathrm{M})$, APC $(96 \mathrm{nM}) / \mathrm{PI}-1(10 \mathrm{nM})$, APC $(48 \mathrm{nM}) / \mathrm{PI}-1$ (7.8 nM), APC (250 nM)/EPM (1.4 nM) and $\operatorname{APC}(125 \mathrm{nM}) / \mathrm{EPM}(2.8 \mathrm{nM})$ on the normal human fibroblast cell line, CRL1554 (B). Control cells were treated with vehicle (DMSO at a final concentration of $0.2 \%$ ). Cell growth was monitored by MTT assay.

apoptosis (24). The unresponsiveness of HeLa cells to apoptosis following the inhibition of HDAC activity by apicidin is due to $\mathrm{NF}-\kappa \mathrm{B}$ activation, which is mediated by IKK and the $\mathrm{I} \kappa \mathrm{B} \alpha$ signaling pathway, indicating that $\mathrm{NF}-\kappa \mathrm{B}$ activation is associated with the resistance of cancer cells to the apoptotic potential of HDACIs (25). Interference with HDACI-mediated $\mathrm{NF}-\kappa \mathrm{B}$ activation would therefore favor the pro-apoptotic actions of HDACIs and enhance HDACI-mediated cell death. Proteasome inhibitors, such as PS-341 and bortezomib, suppress $N F-\kappa B$ activity by inhibiting I $\kappa \mathrm{B} \alpha$ degradation; this activity prevents the nuclear translocation/acetylation of Rel A and interferes with de novo expression of NF- $\kappa \mathrm{B}$-dependent genes, including $\mathrm{I} \kappa \mathrm{B} \alpha(26)$. The aim of the current study was to determine whether the small-molecule proteasome inhibitors could abrogate HDACI (APC)-induced NF- $\kappa$ B activation in colorectal cancer cells and induce their apoptosis. Furthermore, the study aimed to elucidate the associated mechanisms and assess the effects of the combined inhibition of HDACs and the 
Table I. $\mathrm{IC}_{50}-\mathrm{IC}_{80}$ values, the sensitization ratios and P-values of the combined treatment with chemotherapeutic drugs and the combination of APC and MG132 toward human colorectal cancer cell lines.

\begin{tabular}{|c|c|c|}
\hline $\begin{array}{l}\text { Combined treatment with chemotherapeutic drugs and the } \\
\text { combination of APC and proteasome inhibitor MG132 in SW1116 }\end{array}$ & $\begin{array}{l}\mathrm{IC}_{60}(\mathrm{M})^{\mathrm{a}} \\
\mathrm{SW} 1116\end{array}$ & $\begin{array}{c}\mathrm{SR}^{\mathrm{b}} \\
\mathrm{SW} 1116\end{array}$ \\
\hline
\end{tabular}

\begin{tabular}{|c|c|c|c|}
\hline APD $\left(0.28 \times 10^{-5}-17.92 \times 10^{-11} \mathrm{M}\right)+\mathrm{APC} / \mathrm{MG} 132(62 \mathrm{nM} / 0.25 \mu \mathrm{M})$ & $6.3 \times 10^{-9}$ & 47.6 & 0.000 \\
\hline $\begin{array}{l}\text { Combined treatment with chemotherapeutic drugs and the } \\
\text { combination of APC and proteasome inhibitor MG132 in SW1116 }\end{array}$ & $\begin{array}{l}\mathrm{IC}_{70}(\mathrm{M})^{\mathrm{a}} \\
\mathrm{SW} 1116\end{array}$ & $\begin{array}{c}\mathrm{SR}^{\mathrm{b}} \\
\mathrm{SW} 1116\end{array}$ & $\mathrm{P}^{\mathrm{c}}$ \\
\hline
\end{tabular}

TAX $\left(1.46 \times 10^{-4}-93.44 \times 10^{-10} \mathrm{M}\right)+\mathrm{APC} / \mathrm{MG} 132(62 \mathrm{nM} / 0.25 \mu \mathrm{M})$

$26.7 \times 10^{-9} \quad 7.86 \times 10^{2} \quad 0.0001$

Combined treatment with chemotherapeutic drugs and the combination of APC and proteasome inhibitor MG132 in SW1116

$\begin{array}{lc}\mathrm{IC}_{80}(\mathrm{M})^{\mathrm{a}} & \mathrm{SR}^{\mathrm{b}} \\ \mathrm{SW} 1116 & \mathrm{SW} 1116\end{array}$

\begin{tabular}{|c|c|c|c|}
\hline CPT $\left(1.0 \times 10^{-4}-64 \times 10^{-10} \mathrm{M}\right)+\mathrm{APC} / \mathrm{MG} 132(62 \mathrm{nM} / 0.25 \mu \mathrm{M})$ & $2 \times 10^{-7}$ & 20 & 0.0001 \\
\hline CPT $\left(1.0 \times 10^{-4}-64 \times 10^{-10} \mathrm{M}\right)+\mathrm{APC} / \mathrm{MG} 132(240 \mathrm{nM} / 0.16 \mu \mathrm{M})$ & $8.3 \times 10^{-9}$ & $4.8 \times 10^{2}$ & 0.0001 \\
\hline $5 \mathrm{FU}\left(0.65 \times 10^{-3}-41.6 \times 10^{-9} \mathrm{M}\right)+\mathrm{APC} / \mathrm{MG} 132(62 \mathrm{nM} / 0.25 \mu \mathrm{M})$ & $5.5 \times 10^{-6}$ & 25.4 & 0.0001 \\
\hline DOX $\left(0.86 \times 10^{-5}-55 \times 10^{-11} \mathrm{M}\right)+\mathrm{APC} / \mathrm{MG} 132(62 \mathrm{nM} / 0.25 \mu \mathrm{M})$ & $5.16 \times 10^{-9}$ & 16.7 & 0.0001 \\
\hline $\operatorname{VCR}\left(0.25 \times 10^{-5}-16 \times 10^{-11} \mathrm{M}\right)+\operatorname{APC} / \mathrm{MG} 132(62 \mathrm{nM} / 0.25 \mu \mathrm{M})$ & $0.8 \times 10^{-9}$ & 5.0 & 0.0001 \\
\hline $\operatorname{ETP}\left(4.0 \times 10^{-4}-25.6 \times 10^{-10} \mathrm{M}\right)+\operatorname{APC} / \mathrm{MG} 132(62 \mathrm{nM} / 0.25 \mu \mathrm{M})$ & $0.21 \times 10^{-6}$ & 42.8 & 0.0001 \\
\hline $\operatorname{ELP}\left(0.2 \times 10^{-4}-12.8 \times 10^{-10} \mathrm{M}\right)+\mathrm{APC} / \mathrm{MG} 132(62 \mathrm{nM} / 0.25 \mu \mathrm{M})$ & $1.5 \times 10^{-8}$ & $4 \times 10^{2}$ & 0.0001 \\
\hline $\operatorname{AMS}\left(1.25 \times 10^{-5}-80 \times 10^{-11} \mathrm{M}\right)+\mathrm{APC} / \mathrm{MG} 132(62 \mathrm{nM} / 0.25 \mu \mathrm{M})$ & $0.43 \times 10^{-7}$ & 60.5 & 0.0001 \\
\hline HHG $\left(0.2 \times 10^{-5}-12.8 \times 10^{-11} \mathrm{M}\right)+\operatorname{APC} / \mathrm{MG} 132(62 \mathrm{nM} / 0.25 \mu \mathrm{M})$ & $3 \times 10^{-5}$ & 133 & 0.0001 \\
\hline $\begin{array}{l}\text { Combined treatment with chemotherapeutic drugs and the } \\
\text { combination of APC and proteasome inhibitor MG132 in SW837 }\end{array}$ & $\begin{array}{l}\mathrm{IC}_{50}(\mathrm{M})^{\mathrm{a}} \\
\mathrm{SW} 837\end{array}$ & $\begin{array}{c}\mathrm{SR}^{\mathrm{b}} \\
\mathrm{SW} 837\end{array}$ & $\mathrm{P}^{\mathrm{c}}$ \\
\hline CPT $\left(1.0 \times 10^{-4}-64 \times 10^{-10} \mathrm{M}\right)+\mathrm{APC} / \mathrm{MG} 132(240 \mathrm{nM} / 0.16 \mu \mathrm{M})$ & $5.8 \times 10^{-7}$ & 22.4 & 0.027 \\
\hline CPT $\left(1.0 \times 10^{-4}-64 \times 10^{-10} \mathrm{M}\right)+\mathrm{APC} / \mathrm{MG} 132(62 \mathrm{nM} / 0.25 \mu \mathrm{M})$ & $58 \times 10^{-10}$ & $2.24 \times 10^{3}$ & 0.0001 \\
\hline $\operatorname{VCR}\left(0.25 \times 10^{-5}-16 \times 10^{-11} \mathrm{M}\right)+\mathrm{APC} / \mathrm{MG} 132(240 \mathrm{nM} / 0.16 \mu \mathrm{M})$ & $1.60 \times 10^{-10}$ & 18.8 & 0.041 \\
\hline $\operatorname{VCR}\left(0.25 \times 10^{-4}-16 \times 10^{-11} \mathrm{M}\right)+\mathrm{APC} / \mathrm{MG} 132(62 \mathrm{nM} / 0.25 \mu \mathrm{M})$ & $0.67 \times 10^{-9}$ & 4.5 & 0.0001 \\
\hline $\operatorname{ETP}\left(0.4 \times 10^{-4}-25.6 \times 10^{-10} \mathrm{M}\right)+\mathrm{APC} / \mathrm{MG} 132(240 \mathrm{nM} / 0.16 \mu \mathrm{M})$ & $0.28 \times 10^{-5}$ & 14.3 & 0.034 \\
\hline $\operatorname{ETP}\left(0.4 \times 10^{-4}-25.6 \times 10^{-10} \mathrm{M}\right)+\mathrm{APC} / \mathrm{MG} 132(62 \mathrm{nM} / 0.25 \mu \mathrm{M})$ & $0.34 \times 10^{-6}$ & 117.6 & 0.002 \\
\hline $\operatorname{ELP}\left(0.2 \times 10^{-4}-12.8 \times 10^{-10} \mathrm{M}\right)+\mathrm{APC} / \mathrm{MG} 132(240 \mathrm{nM} / 0.16 \mu \mathrm{M})$ & $0.28 \times 10^{-5}$ & 3.7 & 0.173 \\
\hline $\operatorname{ELP}\left(0.2 \times 10^{-4}-12.8 \times 10^{-10} \mathrm{M}\right)+\mathrm{APC} / \mathrm{MG} 132(62 \mathrm{nM} / 0.25 \mu \mathrm{M})$ & $0.57 \times 10^{-6}$ & 17.5 & 0.0001 \\
\hline $\operatorname{AMS}\left(1.25 \times 10^{-5}-80 \times 10^{-11} \mathrm{M}\right)+\mathrm{APC} / \mathrm{MG} 132(240 \mathrm{nM} / 0.16 \mu \mathrm{M})$ & $0.42 \times 10^{-6}$ & 31.0 & 0.019 \\
\hline $\operatorname{AMS}\left(1.25 \times 10^{-5}-80 \times 10^{-11} \mathrm{M}\right)+\mathrm{APC} / \mathrm{MG} 132(62 \mathrm{nM} / 0.25 \mu \mathrm{M})$ & $0.4 \times 10^{-8}$ & $3.25 \times 10^{3}$ & 0.0001 \\
\hline $\begin{array}{l}\text { Combined treatment with chemotherapeutic drugs and the } \\
\text { combination of APC and proteasome inhibitor MG132 in SW837 }\end{array}$ & $\begin{array}{l}\mathrm{IC}_{60}(\mathrm{M})^{\mathrm{a}} \\
\mathrm{SW} 837\end{array}$ & $\begin{array}{c}\mathrm{SR}^{\mathrm{b}} \\
\mathrm{SW} 837\end{array}$ & $\mathrm{P}^{\mathrm{c}}$ \\
\hline $5 \mathrm{FU}\left(0.65 \times 10^{-3}-41.6 \times 10^{-9} \mathrm{M}\right)+\mathrm{APC} / \mathrm{MG} 132(240 \mathrm{nM} / 0.16 \mu \mathrm{M})$ & $2.8 \times 10^{-5}$ & 20.7 & 0.216 \\
\hline $5 \mathrm{FU} \quad\left(0.65 \times 10^{-3}-41.6 \times 10^{-9} \mathrm{M}\right)+\mathrm{APC} / \mathrm{MG} 132(62 \mathrm{nM} / 0.25 \mu \mathrm{M})$ & $21 \times 10^{-8}$ & $2.76 \times 10^{4}$ & 0.0001 \\
\hline $\begin{array}{l}\text { Combined treatment with chemotherapeutic drugs and the } \\
\text { combination of APC and proteasome inhibitor MG132 in SW837 }\end{array}$ & $\begin{array}{l}\mathrm{IC}_{70}(\mathrm{M})^{\mathrm{a}} \\
\mathrm{SW} 837\end{array}$ & $\begin{array}{c}\mathrm{SR}^{\mathrm{b}} \\
\mathrm{SW} 837\end{array}$ & $\mathrm{P}^{\mathrm{c}}$ \\
\hline $\operatorname{DOX}\left(0.86 \times 10^{-5}-55 \times 10^{-11} \mathrm{M}\right)+\mathrm{APC} / \mathrm{MG} 132(240 \mathrm{nM} / 0.16 \mu \mathrm{M})$ & $6.88 \times 10^{-8}$ & 12.5 & 0.171 \\
\hline $\operatorname{DOX}\left(0.86 \times 10^{-5}-55 \times 10^{-11} \mathrm{M}\right)+\mathrm{APC} / \mathrm{MG} 132(62 \mathrm{nM} / 0.25 \mu \mathrm{M})$ & $14 \times 10^{-9}$ & 61.4 & 0.0001 \\
\hline $\operatorname{TAX}\left(1.46 \times 10^{-4}-93.44 \times 10^{-10} \mathrm{M}\right)+\mathrm{APC} / \mathrm{MG} 132(240 \mathrm{nM} / 0.16 \mu \mathrm{M})$ & $7.33 \times 10^{-5}$ & 2.0 & 0.477 \\
\hline TAX $\left(1.46 \times 10^{-4}-93.44 \times 10^{-10} \mathrm{M}\right)+\mathrm{APC} / \mathrm{MG} 132(62 \mathrm{nM} / 0.25 \mu \mathrm{M})$ & $2.93 \times 10^{-6}$ & 50.2 & 0.0001 \\
\hline
\end{tabular}

${ }^{\mathrm{a}}$ The data are based on the mean of absorbance from 3 independent experiments. ${ }^{\mathrm{b}} \mathrm{SR}$, Sensitization ratio $=\mathrm{IC}_{50}$ of drug/IC $\mathrm{C}_{50}$ of the drug + combination of APC and proteasome inhibitors. ${ }^{\mathrm{P}} \mathrm{P}$-value of the combined treatment with standard chemotherapeutic drug and the combination of APC and MG132 versus chemotherapeutic drug alone. 
Table II. $\mathrm{IC}_{50}-\mathrm{IC}_{80}$ values, the sensitization ratios and P-values of the combined treatment with chemotherapeutic drugs and the combination of APC and PI-1 toward human colorectal cancer cell lines.

\begin{tabular}{|c|c|c|c|}
\hline $\begin{array}{l}\text { Combined treatment with chemotherapeutic drugs and the } \\
\text { combination of APC and proteasome inhibitor PI-1 in SW } 1116\end{array}$ & $\begin{array}{l}\mathrm{IC}_{50}(\mathrm{M})^{\mathrm{a}} \\
\mathrm{SW} 1116\end{array}$ & $\begin{array}{c}\mathrm{SR}^{\mathrm{b}} \\
\mathrm{SW} 1116\end{array}$ & $\mathrm{P}^{\mathrm{c}}$ \\
\hline CAP $\left(0.68 \times 10^{-4}-43.52 \times 10^{-10} \mathrm{M}\right)+\mathrm{APC} / \mathrm{PI}-1(48 \mathrm{nM} / 7.8 \mathrm{nM})$ & $5.4 \times 10^{-7}$ & 5.0 & 0.14 \\
\hline CIP $\quad\left(0.42 \times 10^{-3}-26.88 \times 10^{-9} \mathrm{M}\right)+\mathrm{APC} / \mathrm{PI}-1(48 \mathrm{nM} / 7.8 \mathrm{nM})$ & $0.95 \times 10^{-5}$ & 6.3 & 0.216 \\
\hline CIP $\quad\left(0.42 \times 10^{-3}-26.88 \times 10^{-9} \mathrm{M}\right)+\mathrm{APC} / \mathrm{PI}-1(96 \mathrm{nM} / 10 \mathrm{nM})$ & $3.8 \times 10^{-8}$ & $1.58 \times 10^{3}$ & 0.0001 \\
\hline ETP $\left(0.4 \times 10^{-4}-25.6 \times 10^{-10} \mathrm{M}\right)+$ APC/PI-1 $(48 \mathrm{nM} / 7.8 \mathrm{nM})$ & $0.25 \times 10^{-6}$ & 2.9 & 0.244 \\
\hline ETP $\left(0.4 \times 10^{-4}-25.6 \times 10^{-10} \mathrm{M}\right)+$ APC/PI-1 $(96 \mathrm{nM} / 10 \mathrm{nM})$ & $0.38 \times 10^{-8}$ & $1.92 \times 10^{2}$ & 0.004 \\
\hline AMS $\left(1.25 \times 10^{-5}-80 \times 10^{-11} \mathrm{M}\right)+$ APC/PI-1 $(48 \mathrm{nM} / 7.8 \mathrm{nM})$ & $0.04 \times 10^{-6}$ & 6.5 & 0.146 \\
\hline AMS $\left(1.25 \times 10^{-5}-80 \times 10^{-11} \mathrm{M}\right)+\mathrm{APC} / \mathrm{PI}-1(96 \mathrm{nM} / 10 \mathrm{nM})$ & $8 \times 10^{-9}$ & 34.4 & 0.0001 \\
\hline APD $\left(0.28 \times 10^{-5}-17.92 \times 10^{-11} \mathrm{M}\right)+\mathrm{APC} / \mathrm{PI}-1(48 \mathrm{nM} / 7.8 \mathrm{nM})$ & $1.1 \times 10^{-7}$ & 11.8 & 0.007 \\
\hline APD $\left(0.28 \times 10^{-5}-17.92 \times 10^{-11} \mathrm{M}\right)+\mathrm{APC} / \mathrm{PI}-1(96 \mathrm{nM} / 10 \mathrm{nM})$ & $35 \times 10^{-12}$ & $3.71 \times 10^{4}$ & 0.0001 \\
\hline $\begin{array}{l}\text { Combined treatment with chemotherapeutic drugs and the } \\
\text { combination of APC and proteasome inhibitor PI-1 in SW1116 }\end{array}$ & $\begin{array}{l}\mathrm{IC}_{60}(\mathrm{M})^{\mathrm{a}} \\
\mathrm{SW} 1116\end{array}$ & $\begin{array}{c}\mathrm{SR}^{\mathrm{b}} \\
\text { SW1116 }\end{array}$ & $\mathrm{P}^{\mathrm{c}}$ \\
\hline $5 \mathrm{FU}\left(0.65 \times 10^{-3}-41.6 \times 10^{-9} \mathrm{M}\right)+\mathrm{APC} / \mathrm{PI}-1(48 \mathrm{nM} / 7.8 \mathrm{nM})$ & $2.36 \times 10^{-6}$ & 3.3 & 0.871 \\
\hline $5 \mathrm{FU} \quad\left(0.65 \times 10^{-3}-41.6 \times 10^{-9} \mathrm{M}\right)+\mathrm{APC} / \mathrm{PI}-1(96 \mathrm{nM} / 10 \mathrm{nM})$ & $06 \times 10^{-8}$ & 130 & 0.002 \\
\hline OXP $\left(0.06 \times 10^{-4}-4 \times 10^{-10} \mathrm{M}\right)+\mathrm{APC} / \mathrm{PI}-1(48 \mathrm{nM} / 7.8 \mathrm{nM})$ & $0.11 \times 10^{-6}$ & 16.6 & 0.04 \\
\hline OXP $\left(0.06 \times 10^{-4}-4 \times 10^{-10} M\right)+$ APC/PI-1 $(96 \mathrm{nM} / 10 \mathrm{nM})$ & $0.29 \times 10^{-8}$ & $6.22 \times 10^{2}$ & 0.0001 \\
\hline TAX $\left(1.46 \times 10^{-4}-93.44 \times 10^{-10} \mathrm{M}\right)+$ APC/PI-1 $(48 \mathrm{nM} / 7.8 \mathrm{nM})$ & $2.93 \times 10^{-5}$ & 1.4 & 0.165 \\
\hline TAX $\left(1.46 \times 10^{-4}-18.7 \times 10^{-10} \mathrm{M}\right)+$ APC/PI-1 $(96 \mathrm{nM} / 10 \mathrm{nM})$ & $93.6 \times 10^{-10}$ & $4.48 \times 10^{3}$ & 0.0001 \\
\hline $\operatorname{VCR}\left(0.25 \times 10^{-5}-16 \times 10^{-11} \mathrm{M}\right)+\mathrm{APC} / \mathrm{PI}-1(48 \mathrm{nM} / 7.8 \mathrm{nM})$ & $0.23 \times 10^{-9}$ & 3.5 & 0.182 \\
\hline VCR $\left(0.25 \times 10^{-5}-16 \times 10^{-11} \mathrm{M}\right)+\mathrm{APC} / \mathrm{PI}-1(96 \mathrm{nM} / 10 \mathrm{nM})$ & $0.68 \times 10^{-10}$ & 12 & 0.025 \\
\hline ELP $\quad\left(0.2 \times 10^{-4}-12.8 \times 10^{-10} \mathrm{M}\right)+\mathrm{APC} / \mathrm{PI}-1(48 \mathrm{nM} / 7.8 \mathrm{nM})$ & $0.05 \times 10^{-5}$ & 2.4 & 0.323 \\
\hline ELP $\quad\left(0.2 \times 10^{-4}-12.8 \times 10^{-10} \mathrm{M}\right)+\mathrm{APC} / \mathrm{PI}-1(96 \mathrm{nM} / 10 \mathrm{nM})$ & $0.32 \times 10^{-7}$ & 34.4 & 0.008 \\
\hline HHG $\left(0.2 \times 10^{-5}-12.8 \times 10^{-11} \mathrm{M}\right)+$ APC/PI-1 $(48 \mathrm{nM} / 7.8 \mathrm{nM})$ & $0.13 \times 10^{-7}$ & 4.1 & 0.219 \\
\hline HHG $\left(0.2 \times 10^{-5}-12 \times 10^{-11} \mathrm{M}\right)+$ APC/PI-1 $(96 \mathrm{nM} / 10 \mathrm{nM})$ & $1.1 \times 10^{-9}$ & 50 & 0.004 \\
\hline $\begin{array}{l}\text { Combined treatment with chemotherapeutic drugs and the } \\
\text { combination of SCP and proteasome inhibitor PI-1 in SW1116 }\end{array}$ & $\begin{array}{l}\mathrm{IC}_{70}(\mathrm{M})^{\mathrm{a}} \\
\mathrm{SW} 1116\end{array}$ & $\begin{array}{c}\mathrm{SR}^{\mathrm{b}} \\
\text { SW1116 }\end{array}$ & $\mathrm{P}^{\mathrm{c}}$ \\
\hline CPT $\left(1.0 \times 10^{-4}-64 \times 10^{-10} \mathrm{M}\right)+\mathrm{APC} / \mathrm{PI}-1(48 \mathrm{nM} / 7.8 \mathrm{nM})$ & $4.56 \times 10^{-7}$ & 28.5 & 0.478 \\
\hline CPT $\quad\left(1.0 \times 10^{-4}-64 \times 10^{-10} \mathrm{M}\right)+$ APC/PI-1 $(96 \mathrm{nM} / 10 \mathrm{nM})$ & $7.08 \times 10^{-8}$ & 184 & 0.011 \\
\hline DOX $\left(0.86 \times 10^{-5}-55 \times 10^{-11} \mathrm{M}\right)+\mathrm{APC} / \mathrm{PI}-1(48 \mathrm{nM} / 7.8 \mathrm{nM})$ & $0.98 \times 10^{-8}$ & 5 & 0.201 \\
\hline DOX $\left(0.86 \times 10^{-5}-55 \times 10^{-11} \mathrm{M}\right)+$ APC/PI-1 $(96 \mathrm{nM} / 10 \mathrm{nM})$ & $55 \times 10^{-11}$ & 89 & 0.003 \\
\hline $\begin{array}{l}\text { Combined treatment with chemotherapeutic drugs and the } \\
\text { combination of SCP and proteasome inhibitor PI-1 in SW837 }\end{array}$ & $\begin{array}{l}\mathrm{IC}_{50}(\mathrm{M})^{\mathrm{a}} \\
\mathrm{SW} 837\end{array}$ & $\begin{array}{c}\mathrm{SR}^{\mathrm{b}} \\
\mathrm{SW} 837\end{array}$ & $\mathrm{P}^{\mathrm{c}}$ \\
\hline $5 \mathrm{FU}\left(0.65 \times 10^{-3}-41.6 \times 10^{-9} \mathrm{M}\right)+\mathrm{APC} / \mathrm{PI}-1(48 \mathrm{nM} / 7.8 \mathrm{nM})$ & $4.1 \times 10^{-7}$ & 85.4 & 0.0001 \\
\hline OXP $\quad\left(0.06 \times 10^{-4}-4 \times 10^{-10} \mathrm{M}\right)+\mathrm{APC} / \mathrm{PI}-1(48 \mathrm{nM} / 7.8 \mathrm{nM})$ & $0.19 \times 10^{-6}$ & 29 & 0.0001 \\
\hline $\begin{array}{l}\text { Combined treatment with chemotherapeutic drugs and the } \\
\text { combination of SCP and proteasome inhibitor PI-1 in SW837 }\end{array}$ & $\begin{array}{l}\mathrm{IC}_{60}(\mathrm{M})^{\mathrm{a}} \\
\mathrm{SW}\end{array}$ & $\begin{array}{c}\mathrm{SR}^{\mathrm{b}} \\
\mathrm{SW} 837\end{array}$ & $\mathrm{P}^{\mathrm{c}}$ \\
\hline CPT $\quad\left(1.0 \times 10^{-4}-64 \times 10^{-10} \mathrm{M}\right)+\mathrm{APC} / \mathrm{PI}-1(48 \mathrm{nM} / 7.8 \mathrm{nM})$ & $29 \times 10^{-9}$ & 18.1 & 0.0001 \\
\hline $\operatorname{TAX}\left(1.46 \times 10^{-4}-93.44 \times 10^{-10} \mathrm{M}\right)+\mathrm{APC} / \mathrm{PI}-1(48 \mathrm{nM} / 7.8 \mathrm{nM})$ & $11 \times 10^{-7}$ & 25 & 0.0001 \\
\hline TAX $\left(1.46 \times 10^{-4}-93.44 \times 10^{-10} \mathrm{M}\right)+\mathrm{APC} / \mathrm{PI}-1(96 \mathrm{nM} / 10 \mathrm{nM})$ & $187 \times 10^{-7}$ & $1.6 \times 10^{4}$ & 0.0001 \\
\hline AMS $\left(1.25 \times 10^{-5}-80 \times 10^{-11} \mathrm{M}\right)+\mathrm{APC} / \mathrm{PI}-1(48 \mathrm{nM} / 7.8 \mathrm{nM})$ & $0.05 \times 10^{-5}$ & 5.2 & 0.0001 \\
\hline AMS $\left(1.25 \times 10^{-5}-80 \times 10^{-10} \mathrm{M}\right)+\mathrm{APC} / \mathrm{PI}-1(96 \mathrm{nM} / 10 \mathrm{nM})$ & $0.15 \times 10^{-8}$ & $1.73 \times 10^{3}$ & 0.0001 \\
\hline HHG $\left(0.2 \times 10^{-5}-12.8 \times 10^{-11} \mathrm{M}\right)+$ APC/PI-1 $(48 \mathrm{nM} / 7.8 \mathrm{nM})$ & $0.4 \times 10^{-6}$ & 2.5 & 0.053 \\
\hline HHG $\left(0.2 \times 10^{-5}-12.8 \times 10^{-11} \mathrm{M}\right)+$ APC/PI-1 $(96 \mathrm{nM} / 10 \mathrm{nM})$ & $3 \times 10^{-9}$ & 333 & 0.0001 \\
\hline
\end{tabular}


Table II. Continued.

\begin{tabular}{|c|c|c|c|}
\hline $\begin{array}{l}\text { Combined treatment with chemotherapeutic drugs and the } \\
\text { combination of SCP and proteasome inhibitor PI-1 in SW837 }\end{array}$ & $\begin{array}{l}\mathrm{IC}_{70}(\mathrm{M})^{\mathrm{a}} \\
\mathrm{SW} 837\end{array}$ & $\begin{array}{c}\mathrm{SR}^{\mathrm{b}} \\
\mathrm{SW} 837\end{array}$ & $\mathrm{P}^{\mathrm{c}}$ \\
\hline ETP $\left(0.4 \times 10^{-4}-25.6 \times 10^{-10} \mathrm{M}\right)+$ APC/PI-1 $(48 \mathrm{nM} / 7.8 \mathrm{nM})$ & $0.21 \times 10^{-6}$ & $1.33 \times 10^{2}$ & 0.0001 \\
\hline ETP $\left(0.4 \times 10^{-4}-25.6 \times 10^{-10} \mathrm{M}\right)+\mathrm{APC} / \mathrm{PI}-1(96 \mathrm{nM} / 10 \mathrm{nM})$ & $0.51 \times 10^{-8}$ & $5.5 \times 10^{3}$ & 0.0001 \\
\hline ELP $\quad\left(0.2 \times 10^{-4}-12.8 \times 10^{-10} \mathrm{M}\right)+\mathrm{APC} / \mathrm{PI}-1(48 \mathrm{nM} / 7.8 \mathrm{nM})$ & $0.2 \times 10^{-5}$ & 10 & 0.0001 \\
\hline ELP $\quad\left(0.2 \times 10^{-4}-12.8 \times 10^{-10} \mathrm{M}\right)+$ APC/PI-1 $(96 \mathrm{nM} / 10 \mathrm{nM})$ & $2.6 \times 10^{-11}$ & $7.7 \times 10^{4}$ & 0.0001 \\
\hline $\begin{array}{l}\text { Combined treatment with chemotherapeutic drugs and the } \\
\text { combination of SCP and proteasome inhibitor PI-1 in SW837 }\end{array}$ & $\begin{array}{l}\mathrm{IC}_{80}(\mathrm{M})^{\mathrm{a}} \\
\mathrm{SW} 837\end{array}$ & $\begin{array}{c}\mathrm{SR}^{\mathrm{b}} \\
\mathrm{SW} 837\end{array}$ & $\mathrm{P}^{\mathrm{c}}$ \\
\hline DOX $\left(0.86 \times 10^{-5}-55 \times 10^{-11} \mathrm{M}\right)+\mathrm{APC} / \mathrm{PI}-1(48 \mathrm{nM} / 7.8 \mathrm{nM})$ & $1.78 \times 10^{-9}$ & 19.7 & 0.0001 \\
\hline DOX $\left(0.86 \times 10^{-5}-55 \times 10^{-11} \mathrm{M}\right)+\mathrm{APC} / \mathrm{PI}-1(96 \mathrm{nM} / 10 \mathrm{nM})$ & $3.44 \times 10^{-9}$ & 100 & 0.0001 \\
\hline VCR $\left(0.25 \times 10^{-5}-16 \times 10^{-11} \mathrm{M}\right)+\mathrm{APC} / \mathrm{PI}-1(48 \mathrm{nM} / 7.8 \mathrm{nM})$ & $0.8 \times 10^{-9}$ & 7.1 & 0.008 \\
\hline VCR $\left(0.25 \times 10^{-5}-16 \times 10^{-11} M\right)+$ APC/PI-1 $(96 \mathrm{nM} / 10 \mathrm{nM})$ & $1.6 \times 10^{-10}$ & 35.6 & 0.0001 \\
\hline
\end{tabular}

${ }^{a}$ The data are based on the mean of absorbance from 3 independent experiments. ${ }^{\mathrm{b}} \mathrm{SR}$, Sensitization ratio $=\mathrm{IC}_{50}$ of drug/IC $\mathrm{C}_{50}$ of the drug + combination of APC and proteasome inhibitors. ${ }^{\mathrm{C}} \mathrm{P}$-value of the combined treatment with standard chemotherapeutic drug and the combination of APC and PI-1 versus chemotherapeutic drug alone.

Table III. $\mathrm{IC}_{50}-\mathrm{IC}_{80}$ values, the sensitization ratios and P-values of the combined treatment with chemotherapeutic drugs and the combination of APC and EPM toward human colorectal cancer cell lines.

Combined treatment with chemotherapeutic drugs and the combination of APC and proteasome inhibitor EPM in SW1116

\begin{tabular}{rcl}
$\mathrm{IC}_{50}(\mathrm{M})^{\mathrm{a}}$ & \multicolumn{1}{c}{$\mathrm{SR}^{\mathrm{b}}$} & \multicolumn{1}{c}{$\mathrm{P}^{\mathrm{c}}$} \\
$\mathrm{SW} 1116$ & $\mathrm{SW} 1116$ & \\
\hline $2.7 \times 10^{-6}$ & 25.9 & 0.0001 \\
$0.34 \times 10^{-6}$ & $1.17 \times 10^{2}$ & 0.02 \\
$0.14 \times 10^{-8}$ & $2.8 \times 10^{3}$ & 0.0001
\end{tabular}

CAP $\left(0.68 \times 10^{-4}-43.52 \times 10^{-10} \mathrm{M}\right)+\mathrm{APC} / \mathrm{EPM}(123 \mathrm{nM} / 2.8 \mathrm{nM})$

ETP $\left(0.4 \times 10^{-4}-25.6 \times 10^{-10} \mathrm{M}\right)+\mathrm{APC} / \mathrm{EPM}(125 \mathrm{nM} / 2.8 \mathrm{nM})$

$\mathrm{IC}_{60}(\mathrm{M})^{\mathrm{a}}$

SW1116

$\mathrm{SR}^{\mathrm{b}}$

$\mathrm{P}^{\mathrm{c}}$

Combined treatment with chemotherapeutic drugs and the
combination of APC and proteasome inhibitor EPM in SW1116

5 FU $\left(0.65 \times 10^{-3}-41.6 \times 10^{-9} \mathrm{M}\right)+\mathrm{APC} / \mathrm{EPM}(125 \mathrm{nM} / 2.8 \mathrm{nM})$

$5 \mathrm{FU}\left(0.65 \times 10^{-3}-41 \times 10^{-9} \mathrm{M}\right)+\mathrm{APC} / \mathrm{EPM}(250 \mathrm{nM} / 1.4 \mathrm{nM})$

DOX $\left(0.86 \times 10^{-4}-55 \times 10^{-11} \mathrm{M}\right)+\mathrm{APC} / \mathrm{EPM}(125 \mathrm{nM} / 2.8 \mathrm{nM})$

DOX $\left(0.86 \times 10^{-4}-55 \times 10^{-11} \mathrm{M}\right)+\operatorname{APC} / \operatorname{EPM}(250 \mathrm{nM} / 1.4 \mathrm{nM})$

$\operatorname{ELP}\left(0.2 \times 10^{-4}-12.8 \times 10^{-10} \mathrm{M}\right)+\operatorname{APC} / \mathrm{EPM}(125 \mathrm{nM} / 2.8 \mathrm{nM})$

ELP $\left(0.2 \times 10^{-4}-12.8 \times 10^{-10} \mathrm{M}\right)+\operatorname{APC} / \mathrm{EPM}(250 \mathrm{nM} / 1.4 \mathrm{nM})$

AMS $\left(1.25 \times 10^{-5}-80 \times 10^{-11} \mathrm{M}\right)+\mathrm{APC} / \mathrm{EPM}(125 \mathrm{nM} / 2.8 \mathrm{nM})$

AMS $\left(1.3 \times 10^{-5}-80 \times 10^{-11} \mathrm{M}\right)+\operatorname{APC} / \mathrm{EPM}(250 \mathrm{nM} / 1.4 \mathrm{nM})$

HHG $\left(0.2 \times 10^{-5}-12.8 \times 10^{-11} \mathrm{M}\right)+\operatorname{APC} / \mathrm{EPM}(125 \mathrm{nM} / 2.8 \mathrm{nM})$

HHG $\left(0.2 \times 10^{-5}-12.8 \times 10^{-11} \mathrm{M}\right)+\operatorname{APC} / \mathrm{EPM}(250 \mathrm{nM} / 1.4 \mathrm{nM})$

Combined treatment with chemotherapeutic drugs and the combination of APC and proteasome inhibitor EPM in SW1116

$\begin{array}{rcl}0.79 \times 10^{-5} & 2.5 & 0.002 \\ 12 \times 10^{-8} & 1.67 \times 10^{2} & 0.0001 \\ 1.15 \times 10^{-8} & 5 & 0.109 \\ 55 \times 10^{-11} & 1.04 \times 10^{2} & 0.001 \\ 0.04 \times 10^{-4} & 0.8 & 0.503 \\ 0.013 \times 10^{-4} & 0.2 & 0.0001 \\ 0.03 \times 10^{-5} & 26.0 & 0.048 \\ 0.05 \times 10^{-5} & 156 & 0.0001 \\ 0.8 \times 10^{-7} & 5.0 & 0.291 \\ 0.23 \times 10^{-7} & 17.4 & 0.0001\end{array}$

$\mathrm{IC}_{70}(\mathrm{M})^{\mathrm{a}}$

SW1116

$\mathrm{SR}^{\mathrm{b}}$

$\mathrm{P}^{\mathrm{c}}$

SW1116

$\begin{array}{llrrr}\text { CPT } & \left(1.0 \times 10^{-4}-64 \times 10^{-10} \mathrm{M}\right)+\mathrm{APC} / \mathrm{EPM}(125 \mathrm{nM} / 2.8 \mathrm{nM}) & 7 \times 10^{-7} & 5.7 & 0.062 \\ \text { CPT } & \left(1.0 \times 10^{-4}-64 \times 10^{-10} \mathrm{M}\right)+\mathrm{APC} / \mathrm{EPM}(250 \mathrm{nM} / 1.4 \mathrm{nM}) & 14 \times 10^{-8} & 28.6 & 0.0001 \\ \text { TAX } & \left(1.46 \times 10^{-4}-93.44 \times 10^{-10} \mathrm{M}\right)+\mathrm{APC} / \mathrm{EPM}(125 \mathrm{nM} / 2.8 \mathrm{nM}) & 11.7 \times 10^{-8} & 6.7 & 0.001 \\ \text { TAX } & \left(1.46 \times 10^{-4}-93.44 \times 10^{-10} \mathrm{M}\right)+\mathrm{APC} / \mathrm{EPM}(250 \mathrm{nM} / 1.4 \mathrm{nM}) & 46.8 \times 10^{-8} & 16.7 & 0.0001 \\ \text { VCR }\left(0.25 \times 10^{-5}-16 \times 10^{-10} \mathrm{M}\right)+\mathrm{APC} / \mathrm{EPM}(125 \mathrm{nM} / 2.8 \mathrm{nM}) & 0.23 \times 10^{-8} & 1.7 & 0.515 \\ \text { VCR }\left(0.25 \times 10^{-5}-16 \times 10^{-10} \mathrm{M}\right)+\mathrm{APC} / \mathrm{EPM}(250 \mathrm{nM} / 1.4 \mathrm{nM}) & 0.46 \times 10^{-9} & 8.7 & 0.008\end{array}$


Table III. Continued.

\begin{tabular}{|c|c|c|c|}
\hline $\begin{array}{l}\text { Combined treatment with chemotherapeutic drugs and the } \\
\text { combination of SCP and proteasome inhibitor EPM in SW837 }\end{array}$ & $\begin{array}{l}\mathrm{IC}_{50}(\mathrm{M})^{\mathrm{a}} \\
\mathrm{SW} 837\end{array}$ & $\begin{array}{c}\mathrm{SR}^{\mathrm{b}} \\
\mathrm{SW} 837\end{array}$ & $\mathrm{P}^{\mathrm{c}}$ \\
\hline CAP $\left(0.68 \times 10^{-4}-43.52 \times 10^{-10} \mathrm{M}\right)+\operatorname{APC} / \mathrm{EPM}(125 \mathrm{nM} / 2.8 \mathrm{nM})$ & $2.7 \times 10^{-6}$ & 26 & 0.0001 \\
\hline $\operatorname{VCR}\left(0.25 \times 10^{-5}-16 \times 10^{-11} \mathrm{M}\right)+\mathrm{APC} / \mathrm{EPM}(125 \mathrm{nM} / 2.8 \mathrm{nM})$ & $0.4 \times 10^{-8}$ & 3.3 & 0.274 \\
\hline VCR $\left(0.25 \times 10^{-5}-16 \times 10^{-11} \mathrm{M}\right)+\mathrm{APC} / \mathrm{EPM}(250 \mathrm{nM} / 1.4 \mathrm{nM})$ & $0.53 \times 10^{-9}$ & 24.5 & 0.004 \\
\hline ETP $\left(0.4 \times 10^{-4}-25.4 \times 10^{-10} \mathrm{M}\right)+\mathrm{APC} / \mathrm{EPM}(125 \mathrm{nM} / 2.8 \mathrm{nM})$ & $0.085 \times 10^{-5}$ & 47.0 & 0.061 \\
\hline ETP $\left(0.4 \times 10^{-4}-25.4 \times 10^{-10} \mathrm{M}\right)+\mathrm{APC} / \mathrm{EPM}(250 \mathrm{nM} / 1.4 \mathrm{nM})$ & $0.7 \times 10^{-7}$ & $5.7 \times 10^{2}$ & 0.0001 \\
\hline $\operatorname{ELP} \quad\left(0.2 \times 10^{-4}-12.8 \times 10^{-10} \mathrm{M}\right)+\mathrm{APC} / \mathrm{EPM}(125 \mathrm{nM} / 2.8 \mathrm{nM})$ & $0.04 \times 10^{-4}$ & 2.5 & 0.543 \\
\hline $\operatorname{ELP} \quad\left(0.2 \times 10^{-4}-12.8 \times 10^{-10} \mathrm{M}\right)+\mathrm{APC} / \mathrm{EPM}(250 \mathrm{nM} / 1.4 \mathrm{nM})$ & $0.013 \times 10^{-5}$ & 77 & 0.0001 \\
\hline AMS $\left(1.25 \times 10^{-5}-80 \times 10^{-11} \mathrm{M}\right)+\mathrm{APC} / \mathrm{EPM}(125 \mathrm{nM} / 2.8 \mathrm{nM})$ & $0.04 \times 10^{-5}$ & 5.3 & 0.166 \\
\hline $\operatorname{AMS}\left(1.25 \times 10^{-5}-80 \times 10^{-11} \mathrm{M}\right)+\mathrm{APC} / \mathrm{EPM}(250 \mathrm{nM} / 1.4 \mathrm{nM})$ & $0.03 \times 10^{-6}$ & 7.0 & 0.0001 \\
\hline HHG $\left(0.2 \times 10^{-5}-12.8 \times 10^{-11} \mathrm{M}\right)+\mathrm{APC} / \mathrm{EPM}(125 \mathrm{nM} / 2.8 \mathrm{nM})$ & $0.17 \times 10^{-6}$ & 2.4 & 0.473 \\
\hline HHG $\left(0.2 \times 10^{-5}-12.8 \times 10^{-11} \mathrm{M}\right)+\mathrm{APC} / \mathrm{EPM}(250 \mathrm{nM} / 1.4 \mathrm{nM})$ & $0.43 \times 10^{-9}$ & 9.3 & 0.002 \\
\hline $\begin{array}{l}\text { Combined treatment with chemotherapeutic drugs and the } \\
\text { combination of SCP and proteasome inhibitor EPM in SW837 }\end{array}$ & $\begin{array}{l}\mathrm{IC}_{70}(\mathrm{M})^{\mathrm{a}} \\
\mathrm{SW} 837\end{array}$ & $\begin{array}{c}\mathrm{SR}^{\mathrm{b}} \\
\mathrm{SW} 837\end{array}$ & $\mathrm{P}^{\mathrm{c}}$ \\
\hline $\mathrm{CPT} \quad\left(1.0 \times 10^{-4}-64 \times 10^{-10} \mathrm{M}\right)+\mathrm{APC} / \mathrm{EPM}(125 \mathrm{nM} / 2.8 \mathrm{nM}$ & $2.3 \times 10^{-7}$ & 43.4 & 0.0001 \\
\hline CPT $\quad\left(1.0 \times 10^{-4}-64 \times 10^{-10} \mathrm{M}\right)+\mathrm{APC} / \mathrm{EPM}(250 \mathrm{nM} / 1.4 \mathrm{nM})$ & $7.3 \times 10^{-8}$ & 137 & 0.0001 \\
\hline $5 \mathrm{FU}\left(0.65 \times 10^{-3}-41.6 \times 10^{-9} \mathrm{M}\right)+\mathrm{APC} / \mathrm{EPM}(125 \mathrm{nM} / 2.8 \mathrm{nM})$ & $0.46 \times 10^{-5}$ & 20.2 & 0.0001 \\
\hline $5 \mathrm{FU}\left(0.65 \times 10^{-3}-41.6 \times 10^{-9} \mathrm{M}\right)+\mathrm{APC} / \mathrm{EPM}(250 \mathrm{nM} / 1.4 \mathrm{nM})$ & $11 \times 10^{-7}$ & 84.5 & 0.0001 \\
\hline DOX $\left(0.86 \times 10^{-5}-55 \times 10^{-11} \mathrm{M}\right)+\mathrm{APC} / \mathrm{EPM}(125 \mathrm{nM} / 2.8 \mathrm{nM})$ & $11.4 \times 10^{-9}$ & 1.0 & 0.009 \\
\hline DOX $\left(0.86 \times 10^{-5}-55 \times 10^{-11} \mathrm{M}\right)+\mathrm{APC} / \mathrm{EPM}(250 \mathrm{nM} / 1.4 \mathrm{nM})$ & $4.6 \times 10^{-9}$ & 2.5 & 0.0001 \\
\hline $\begin{array}{l}\text { Combined treatment with chemotherapeutic drugs and the } \\
\text { combination of SCP and proteasome inhibitor EPM in SW837 }\end{array}$ & $\begin{array}{l}\mathrm{IC}_{80}(\mathrm{M})^{\mathrm{a}} \\
\mathrm{SW} 837\end{array}$ & $\begin{array}{c}\mathrm{SR}^{\mathrm{b}} \\
\mathrm{SW} 837\end{array}$ & $\mathrm{P}^{\mathrm{c}}$ \\
\hline $\operatorname{TAX}\left(1.46 \times 10^{-4}-93.44 \times 10^{-10} \mathrm{M}\right)+\mathrm{APC} / \mathrm{EPM}(125 \mathrm{nM} / 2.8 \mathrm{nM})$ & $7.8 \times 10^{-7}$ & 7.5 & 0.019 \\
\hline TAX $\left(1.46 \times 10^{-4}-93.44 \times 10^{-10} \mathrm{M}\right)+\operatorname{APC} / \mathrm{EPM}(250 \mathrm{nM} / 1.4 \mathrm{nM})$ & $15.6 \times 10^{-8}$ & 37.6 & 0.0001 \\
\hline
\end{tabular}

${ }^{\mathrm{a}}$ The data are based on the mean of absorbance from 3 independent experiments. ${ }^{\mathrm{b}} \mathrm{SR}$, Sensitization ratio $=\mathrm{IC}_{50}$ of drug/IC $\mathrm{C}_{50}$ of the drug + combination of APC and proteasome inhibitors. ${ }^{\mathrm{C}} \mathrm{P}$-value of the combined treatment with standard chemotherapeutic drug and the combination of apicidin and epoxomicin versus chemotherapeutic drug alone.

proteasome on the response of human colorectal cancer cells to chemotherapy.

New combination therapies for cancer are expected to produce enhanced efficacy, improved selectivity, and reduced toxicity. An ideal combination regimen would consist of agents with different mechanisms of action, leading to complementary antitumor activities and little cross resistance (27). In the present study, exposure to submicromolar concentrations of APC in combination with submicromolar concentrations of MG132 and nanomolar concentrations of EPM or PI-1 synergistically decreased the survival of cancer cells when compared with the single treatments (Fig. 1A). MG132 $(0.3 \mu \mathrm{M})$ increased the sensitivity of both SW1116 $(\mathrm{SR}=2.64)$ and $\mathrm{SW} 837$ ( $\mathrm{SR}=2.5)$ cells to APC. PI-1 (7.8 $\mathrm{nM})$ increased the sensitivity of SW1116 (SR=2.8) and SW837 $(\mathrm{SR}=2.15)$ to $\mathrm{APC}$, and at $15.6 \mathrm{nM}, \mathrm{PI}-1$ further increased the sensitivity of SW1116 ( $\mathrm{SR}=4.63)$ and SW $837(\mathrm{SR}=3.3)$ cells to APC. Finally, EPM (2.8 nM) increased the sensitivity of SW1116 $(\mathrm{SR}=1.91)$ and $\mathrm{SW837}(\mathrm{SR}=3.29)$ cells to APC.
Colony formation assays (Fig. 1B) and morphological changes (Fig. 1C) confirmed the results of the inhibition studies. Both APC and the tested proteasome inhibitors had little toxic effects on normal human fibroblasts. Cancer cells rely heavily on the proteasome to eliminate unwanted proteins, most likely due to their rapid protein turnover rate; therefore, cancer cells are more susceptible to proteasome inhibition when compared with non-transformed cells (28). Our results are consistent with previous studies reported by several groups using diverse malignant cell types and employing various combinations of HDAC and proteasome inhibitors $(22,25,29)$.

The rationale to target the proteasome in cancer cells stems from data indicating that malignant cells accumulate more misfolded, mutated, or damaged proteins, which are disposed of by the proteasome; therefore, cancer cells are more dependent on proteasome activity (30). Furthermore, the inhibition of the proteasome induces apoptosis and has been shown to have antitumor effects in several xenograft models and cancer cell lines representing prostate, pancreas (31), lymphoma, 
Table IV. Percentage means cytotoxicity of standard chemotherapeutic drugs and their combinations with APC/MG132 or PI-1 on human colorectal cancer cells.

Treatment with chemotherapeutic drugs and the combinations of APC/MG132

5FU $\quad\left(0.65 \times 10^{-3}-41.6 \times 10^{-9} \mathrm{M}\right)$

$5 \mathrm{FU} \quad\left(0.65 \times 10^{-3}-41.6 \times 10^{-9} \mathrm{M}\right)+\mathrm{APC} / \mathrm{MG} 132(240 \mathrm{nM} / 0.16 \mu \mathrm{M})$

OXP $\left(0.06 \times 10^{-4}-4 \times 10^{-10} \mathrm{M}\right)$

OXP $\left(0.06 \times 10^{-4}-4 \times 10^{-10} \mathrm{M}\right)+\mathrm{APC} / \mathrm{MG} 132(62 \mathrm{nM} / 0.25 \mu \mathrm{M})$

OXP $\left(0.06 \times 10^{-4}-4 \times 10^{-10} \mathrm{M}\right)+\mathrm{APC} / \mathrm{MG} 132(240 \mathrm{nM} / 0.16 \mu \mathrm{M})$

DOX $\left(0.86 \times 10^{-5}-55 \times 10^{-11} \mathrm{M}\right)$

DOX $\left(0.86 \times 10^{-5}-55 \times 10^{-11} \mathrm{M}\right)+\mathrm{APC} / \mathrm{MG} 132(240 \mathrm{nM} / 0.16 \mu \mathrm{M})$

CAP $\left(0.68 \times 10^{-4}-43.52 \times 10^{-10} \mathrm{M}\right)$

CAP $\left(0.68 \times 10^{-4}-43.52 \times 10^{-10} \mathrm{M}\right)+\mathrm{APC} / \mathrm{MG} 132(62 \mathrm{nM} / 0.25 \mu \mathrm{M})$

CAP $\left(0.68 \times 10^{-4}-43.52 \times 10^{-10} \mathrm{M}\right)+\mathrm{APC} / \mathrm{MG} 132(240 \mathrm{nM} / 0.16 \mu \mathrm{M})$

CIP $\quad\left(0.42 \times 10^{-3}-26 \times 10^{-9} \mathrm{M}\right)$

CIP $\quad\left(0.42 \times 10^{-3}-26 \times 10^{-9} \mathrm{M}\right)+\mathrm{APC} / \mathrm{MG} 132(62 \mathrm{nM} / 0.25 \mu \mathrm{M})$

CIP $\left(0.42 \times 10^{-3}-26 \times 10^{-9} \mathrm{M}\right)+\mathrm{APC} / \mathrm{MG} 132(240 \mathrm{nM} / 0.16 \mu \mathrm{M})$

TAX $\left(1.46 \times 10^{-4}-93.44 \times 10^{-10} \mathrm{M}\right)$

TAX $\left(1.46 \times 10^{-4}-93.44 \times 10^{-10} \mathrm{M}\right)+\mathrm{APC} / \mathrm{MG} 132(62 \mathrm{nM} / 0.25 \mu \mathrm{M})$

TAX $\left(1.46 \times 10^{-4}-93.44 \times 10^{-10} \mathrm{M}\right)+\mathrm{APC} / \mathrm{MG} 132(240 \mathrm{nM} / 0.16 \mu \mathrm{M})$

CPA $\left(1 \times 10^{-4}-64 \times 10^{-10} \mathrm{M}\right)$

$\mathrm{CPA}\left(1 \times 10^{-4}-64 \times 10^{-10} \mathrm{M}\right)+\mathrm{APC} / \mathrm{MG} 132(62 \mathrm{nM} / 0.25 \mu \mathrm{M})$

CPA $\left(1 \times 10^{-4}-64 \times 10^{-10} \mathrm{M}\right)+\mathrm{APC} / \mathrm{MG} 132(240 \mathrm{nM} / 0.16 \mu \mathrm{M})$

VCR $\left(0.25 \times 10^{-4}-16 \times 10^{-11} \mathrm{M}\right)$

VCR $\left(0.25 \times 10^{-4}-16 \times 10^{-11} \mathrm{M}\right)+\mathrm{APC} / \mathrm{MG} 132(240 \mathrm{nM} / 0.16 \mu \mathrm{M})$

ETP $\left(4 \times 10^{-4}-25.6 \times 10^{-10} \mathrm{M}\right)$

ETP $\left(4 \times 10^{-4}-25.6 \times 10^{-10} \mathrm{M}\right)+\mathrm{APC} / \mathrm{MG} 132(240 \mathrm{nM} / 0.16 \mu \mathrm{M})$

ELP $\quad\left(0.2 \times 10^{-4}-12.8 \times 10^{-10} \mathrm{M}\right)$

ELP $\left(0.2 \times 10^{-4}-12.8 \times 10^{-10} \mathrm{M}\right)+\mathrm{APC} / \mathrm{MG} 132(240 \mathrm{nM} / 0.16 \mu \mathrm{M})$

AMS $\left(1.25 \times 10^{-5}-80 \times 10^{-11} \mathrm{M}\right)$

AMS $\left(1.25 \times 10^{-5}-80 \times 10^{-11} \mathrm{M}\right)+\mathrm{APC} / \mathrm{MG} 132(240 \mathrm{nM} / 0.16 \mu \mathrm{M})$

HHG $\left(0.2 \times 10^{-5}-12.8 \times 10^{-11} \mathrm{M}\right)$

HHG $\left(0.2 \times 10^{-5}-12.8 \times 10^{-11} \mathrm{M}\right)+\mathrm{APC} / \mathrm{MG} 132(62 \mathrm{nM} / 0.25 \mu \mathrm{M})$

HHG $\left(0.2 \times 10^{-5}-12.8 \times 10^{-11} \mathrm{M}\right)+\mathrm{APC} / \mathrm{MG} 132(240 \mathrm{nM} / 0.16 \mu \mathrm{M})$

APD $\left(0.28 \times 10^{-5}-17.92 \times 10^{-11} \mathrm{M}\right)$

APD $\left(0.28 \times 10^{-5}-17.92 \times 10^{-11} \mathrm{M}\right)+\mathrm{APC} / \mathrm{MG} 132(62 \mathrm{nM} / 0.25 \mu \mathrm{M})$

APD $\left(0.28 \times 10^{-5}-17.92 \times 10^{-11} \mathrm{M}\right)+\mathrm{APC} / \mathrm{MG} 132(240 \mathrm{nM} / 0.16 \mu \mathrm{M})$

Treatment with chemotherapeutic drugs and the combinations of APC/PI-1

${ }^{a}$ The data are based on the mean of absorbance from 3 independent experiments. ${ }^{\mathrm{b}} \mathrm{P}$-value of the combined treatment with standard chemotherapeutic drug and the combination of APC and MG132 or PI-1 versus chemotherapeutic drug alone.

CPT $\left(1.0 \times 10^{-4}-64 \times 10^{-10} \mathrm{M}\right)$

CPT $\left(1.0 \times 10^{-4}-64 \times 10^{-10} \mathrm{M}\right)+\mathrm{APC} / \mathrm{PI}-1(96 \mathrm{nM} / 10 \mathrm{nM})$

OXP $\left(0.04 \times 10^{-4}-4 \times 10^{-10} \mathrm{M}\right)$

OXP $\left(0.04 \times 10^{-4}-4 \times 10^{-10} \mathrm{M}\right)+\mathrm{APC} / \mathrm{PI}-1(96 \mathrm{nM} / 10 \mathrm{nM})$

CAP $\left(0.68 \times 10^{-4}-43.5 \times 10^{-10} \mathrm{M}\right)$

CAP $\left(0.68 \times 10^{-4}-43.5 \times 10^{-10} \mathrm{M}\right)+\mathrm{APC} / \mathrm{PI}-1(48 \mathrm{nM} / 7.8 \mathrm{nM})$

CAP $\left(0.68 \times 10^{-4}-43.5 \times 10^{-10} \mathrm{M}\right)+\mathrm{APC} / \mathrm{PI}-1(96 \mathrm{nM} / 10 \mathrm{nM})$
Percentage means

cytotoxicity $^{\mathrm{a}}$

\begin{tabular}{|c|c|c|c|}
\hline SW1116 & SW837 & SW1116 & SW837 \\
\hline \multicolumn{4}{|l|}{$52 \pm 4.5$} \\
\hline $93 \pm 0.4$ & - & 0.0001 & - \\
\hline $40 \pm 2.3$ & $2 \pm 0.9$ & & \\
\hline $79 \pm 1.3$ & $5 \pm 3$ & 0.0001 & - \\
\hline $93 \pm 0.23$ & $61 \pm 1.2$ & 0.0001 & 0.0001 \\
\hline \multicolumn{4}{|l|}{$65 \pm 5.4$} \\
\hline $97 \pm 2.5$ & - & 0.0001 & - \\
\hline $33 \pm 2.9$ & $3.4 \pm 1.5$ & & \\
\hline $74 \pm 1.9$ & $10 \pm 4$ & 0.0001 & 0.085 \\
\hline $93 \pm 0.4$ & $61 \pm 0.9$ & 0.0001 & 0.0001 \\
\hline $31 \pm 2.2$ & 0.0 & & \\
\hline $77 \pm 1.5$ & $2 \pm 0.9$ & 0.0001 & - \\
\hline $95 \pm 3.3$ & $67 \pm 1$ & 0.0001 & 0.0001 \\
\hline \multicolumn{4}{|l|}{$42 \pm 4.8$} \\
\hline $79 \pm 2.6$ & - & 0.0001 & - \\
\hline $94 \pm 0.5$ & - & 0.0001 & - \\
\hline $14 \pm 1$ & 0.0 & & \\
\hline $60 \pm 1.3$ & $0.4 \pm 0.2$ & 0.0001 & - \\
\hline $92 \pm 0.4$ & $48 \pm 1.3$ & 0.0001 & 0.0001 \\
\hline \multicolumn{4}{|l|}{$74 \pm 4$} \\
\hline $96 \pm 0.5$ & - & 0.0001 & - \\
\hline \multicolumn{4}{|l|}{$51 \pm 4.8$} \\
\hline $95 \pm 0.5$ & - & 0.0001 & - \\
\hline \multicolumn{4}{|l|}{$40 \pm 5.4$} \\
\hline $95 \pm 0.4$ & - & 0.0001 & - \\
\hline \multicolumn{4}{|l|}{$49 \pm 4.3$} \\
\hline $95 \pm 0.6$ & - & 0.0001 & - \\
\hline $50 \pm 4.8$ & $9 \pm 3$ & & \\
\hline- & $16 \pm 5$ & - & 0.243 \\
\hline $94 \pm 0.7$ & $56 \pm 4.8$ & 0.0001 & 0.0001 \\
\hline $36 \pm 3$ & 0.0 & & \\
\hline- & $9 \pm 4$ & - & 0.045 \\
\hline $94 \pm 0.6$ & $44 \pm 4$ & 0.0001 & 0.0001 \\
\hline
\end{tabular}

Percentage means cytotoxicity

\begin{tabular}{ccccc}
\cline { 5 - 5 } \cline { 5 - 5 } SW1116 & SW837 & & SW1116 & SW837 \\
& & $47 \pm 6$ & & \\
& & $93 \pm 1.6$ & & 0.0001 \\
& & $19 \pm 3.5$ & & \\
& - & $78 \pm 1.8$ & & 0.0001 \\
$42 \pm 2.3$ & $15 \pm 2.6$ & & \\
& - & $38 \pm 1$ & & 0.0001 \\
& $68 \pm 1.9$ & $62 \pm 2.5$ & 0.0001 & 0.0001
\end{tabular}

P-values ${ }^{b}$

P-values 
Table V. Percentage means cytotoxicity of standard chemotherapeutic drugs and their combinations with APC/ PI-1 or EPM on human colorectal cancer cells.

Treatment with chemotherapeutic drugs and the combinations of APC/PI-1

\begin{tabular}{|c|c|c|c|c|c|}
\hline \multirow{2}{*}{\multicolumn{2}{|c|}{$\begin{array}{l}\text { Treatment with chemotherapeutic drugs and the combinations } \\
\text { of APC/PI-1 }\end{array}$}} & \multirow{2}{*}{ SW1116 } & \multirow[b]{2}{*}{ SW837 } & \\
\hline & & & & SW1116 & SW837 \\
\hline CIP & $\left(0.42 \times 10^{-3}-26.88 \times 10^{-9} \mathrm{M}\right)$ & - & $2 \pm 0.9$ & & \\
\hline CIP & $\left(0.42 \times 10^{-3}-26.88 \times 10^{-9} \mathrm{M}\right)+\mathrm{APC} / \mathrm{PI}-1(48 \mathrm{nM} / 7.8 \mathrm{nM})$ & - & $42 \pm 1.6$ & - & 0.0001 \\
\hline CIP & $\left(0.42 \times 10^{-3}-26.88 \times 10^{-9} \mathrm{M}\right)+\mathrm{APC} / \mathrm{PI}-1(96 \mathrm{nM} / 10 \mathrm{nM})$ & - & $67 \pm 1.2$ & - & 0.0001 \\
\hline CPA & $\left(1 \times 10^{-4}-64 \times 10^{-10} M\right)$ & $41 \pm 1.2$ & $7 \pm 1.6$ & & \\
\hline CPA & $\left(1 \times 10^{-4}-64 \times 10^{-10} \mathrm{M}\right)+\mathrm{APC} / \mathrm{PI}-1(48 \mathrm{nM} / 7.8 \mathrm{nM})$ & $42 \pm 2.1$ & $49 \pm 1.6$ & 0.814 & 0.0001 \\
\hline CPA & $\left(1 \times 10^{-4}-64 \times 10^{-10} \mathrm{M}\right)+\mathrm{APC} / \mathrm{PI}-1(96 \mathrm{nM} / 10 \mathrm{nM})$ & $71 \pm 1.0$ & $70 \pm 1.5$ & 0.0001 & 0.0001 \\
\hline APD & $\left(0.28 \times 10^{-5}-17.92 \times 10^{-11} \mathrm{M}\right)$ & - & $13 \pm 3.2$ & & \\
\hline APD & $\left(0.28 \times 10^{-5}-17.92 \times 10^{-11} \mathrm{M}\right)+\mathrm{APC} / \mathrm{PI}-1(48 \mathrm{nM} / 7.8 \mathrm{nM})$ & - & $19 \pm 3.9$ & - & 0.208 \\
\hline APD & $\left(0.28 \times 10^{-5}-17.92 \times 10^{-11} \mathrm{M}\right)+\mathrm{APC} / \mathrm{PI}-1(96 \mathrm{nM} / 10 \mathrm{nM})$ & - & $39 \pm 3.3$ & & 0.0001 \\
\hline
\end{tabular}

Treatment with chemotherapeutic drugs and the combinations of $\mathrm{APC} / \mathrm{EPM}$

Percentage means cytotoxicity
Percentage means cytotoxicity $^{\mathrm{a}}$
P-values ${ }^{\mathrm{b}}$

\begin{tabular}{llllr}
\hline OXP & $\left(0.06 \times 10^{-4}-4 \times 10^{-10} \mathrm{M}\right)$ & $08 \pm 2.9$ & $36 \pm 2$ & \\
OXP $\left.\left(0.06 \times 10^{-4}-4 \times 10^{-10} \mathrm{M}\right)+\mathrm{APC} / \mathrm{EPM}(125 \mathrm{nM}) / 2.8 \mathrm{nM}\right)$ & $32 \pm 2.9$ & $47 \pm 2.3$ & 0.0001 \\
OXP $\left(0.06 \times 10^{-4}-4 \times 10^{-10} \mathrm{M}\right)+\mathrm{APC} / \mathrm{EPM}(250 \mathrm{nM} / 1.4 \mathrm{nM})$ & $60 \pm 3$ & $69 \pm 1.7$ & 0.0001 \\
CAP $\left(0.68 \times 10^{-4}-43.52 \times 10^{-10} \mathrm{M}\right)$ & $30 \pm 2.2$ & $28 \pm 2.1$ & 0.0001 \\
CAP $\left(0.68 \times 10^{-4}-43.52 \times 10^{-10} \mathrm{M}\right)+\mathrm{APC} / \mathrm{EPM}(250 \mathrm{nM} / 1.4 \mathrm{nM})$ & $49 \pm 2.3$ & $67 \pm 2.2$ & 0.0001 \\
CIP $\left(0.42 \times 10^{-3}-26.88 \times 10^{-9} \mathrm{M}\right)$ & $61 \pm 3$ & $29 \pm 2.4$ & 0.0001 \\
CIP $\left.\left(0.42 \times 10^{-3}-26.88 \times 10^{-9} \mathrm{M}\right)+\mathrm{APC} / \mathrm{EPM}(125 \mathrm{nM}) / 2.8 \mathrm{nM}\right)$ & $30 \pm 2.8$ & $50 \pm 2.5$ & 0.0001 \\
CIP $\left(0.42 \times 10^{-3}-26.88 \times 10^{-9} \mathrm{M}\right)+\mathrm{APC} / \mathrm{EPM}(250 \mathrm{nM} / 1.4 \mathrm{nM})$ & $61 \pm 3$ & $67 \pm 1.76$ & 0.0001 \\
CPA $\left(1 \times 10^{-4}-64 \times 10^{-10} \mathrm{M}\right)$ & 0.0 & 0.0 & 0.0001 \\
CPA $\left(1 \times 10^{-4}-64 \times 10^{-10} \mathrm{M}\right)+\mathrm{APC} / \mathrm{EPM}(250 \mathrm{nM} / 1.4 \mathrm{nM})$ & $57 \pm 3$ & $35 \pm 1.5$ & 0.0001 \\
APD $\left(0.28 \times 10^{-5}-17.92 \times 10^{-11} \mathrm{M}\right)$ & $5 \pm 2.4$ & $7 \pm 1.6$ & 0.0001 \\
APD $\left.\left(0.28 \times 10^{-5}-17.92 \times 10^{-11} \mathrm{M}\right)+\mathrm{APC} / \mathrm{EPM}(125 \mathrm{nM}) / 2.8 \mathrm{nM}\right)$ & $19 \pm 3.5$ & $22 \pm 2.7$ & 0.001 \\
APD $\left(0.28 \times 10^{-5}-17.92 \times 10^{-11} \mathrm{M}\right)+\mathrm{APC} / \mathrm{EPM}(250 \mathrm{nM} / 1.4 \mathrm{nM})$ & $55 \pm 2.9$ & $67 \pm 3.3$ & 0.0001 \\
\hline
\end{tabular}

${ }^{a}$ The data are based on the mean of absorbance from 3 independent experiments. ${ }^{b}$-value of the combined treatment with standard chemotherapeutic drug and the combination of APC and PI-1 or EPM versus chemotherapeutic drug alone.

head and neck, melanoma, lung, and breast cancers as well as leukemias (32).

The acetylation and deacetylation of histone proteins control gene transcription, and the processes are regulated by two families of enzymes, acetyltransferases and HDACs (33). Increased histone acetylation is typically associated with transcriptionally active genes, whereas low levels of acetylation correlate with transcriptional repression (33). In the present study, APC treatment resulted in a significant inhibition $(\mathrm{P} \leq 0.0001)$ of intranuclear deacetylase activity, and the data were in agreement with the antimitogenic effect of APC on human colorectal cancer cells (Fig. 2A). These findings are consistent with those reported for other HDACIs, such as TSA and sodium butyrate, on head and neck squamous cell cancer cell lines (34). However, data reported by Denlinger et al indicated that although all intracellular deacetylase activity was inhibited in three different non-small cell lung cancer
(NSCLC) cell lines, they were resistant to HDAC inhibitormediated cell death (35).

$\mathrm{NF}-\kappa \mathrm{B}$, which is thought to be targeted by proteasome inhibitors, is a transcription factor regulating gene involved in proliferation, apoptosis, and angiogenesis, and it is particularly well studied as the main effector of apoptosis. NF- $\kappa \mathrm{B}$ is known to be overexpressed or constitutively active in a number of human tumor types, possibly conferring resistance to cancer cell death (36). HDACIs have been shown to exert pleiotropic effects on $\mathrm{NF}-\kappa \mathrm{B}$ activity in various cell types, including producing an increase in activity in some cells (37) and a decrease in activity in others (38). Whether this discrepancy reflects concentration-, drug-, or cell type-specific differences remains to be determined. In any case, in the present study, APC significantly increased $(\mathrm{P} \leq 0.022)$ the DNA binding activity of $\mathrm{NF}-\kappa \mathrm{B}$. On the other hand, the MG132 $(\mathrm{P} \leq 0.87)$, PI-1 $(\mathrm{P} \leq 0.419)$ and EPM $(\mathrm{P} \leq 0.352)$ proteasome inhibitors 
decreased the DNA binding activity of NF- $\kappa$ B. This activity was decreased even more significantly after the combined treatment of APC with MG132 (P $\leq 0.008)$, PI-1 $(\mathrm{P} \leq 0.01)$ or EPM (P $\leq 0.001)$ (Fig. 2B), suggesting their synergic mechanism as negative regulators of the $N F-\kappa B$ pathway. These findings are consistent with data obtained using HDACIs and PIs in other malignancies $(25,39)$.

Proteasome inhibitors act by targeting the catalytic core of the proteasome and inducing the apoptosis of tumor cells. Among other mechanisms, proteasome inhibitors lead to the cytoplasmic accumulation of the $\mathrm{I}-\kappa \mathrm{B}$ protein and reduced $\mathrm{NF}-\kappa \mathrm{B}$ activity. Other downstream targets involved in the action of proteasome inhibitors include the generation of ROS, caspase activation and accumulation of cellular proteins linked to cell proliferation and apoptosis (40).

In the present study, the tested proteasome inhibitors, MG132 (P $\leq 0.001)$, EPM ( $\mathrm{P} \leq 0.001)$, and PI-1 $(\mathrm{P} \leq 0.0001)$, as well as their combination with APC significantly suppressed $(\mathrm{P} \leq 0.0001)$ proteasome activity in colorectal cancer cells when compared with untreated cells (Fig. 2C). Such findings are in agreement with findings in other malignancies (41). Previous studies have suggested that the lethal effects of proteasome inhibitors either administered alone in lung cancer cells (42) or in combination with HDACIs in $\mathrm{Bcr} / \mathrm{Abl}^{+}$myeloid leukemia cells (43) stem from the generation of ROS.

Studies were therefore performed to determine whether a similar mechanism might underlie the lethality of APC/PI combination treatment in colorectal cancer cells. The combined treatment with APC/MG132, APC/EPM and APC/PI-1 showed a pronounced generation of $\operatorname{ROS}(\mathrm{P} \leq 0.0001)$ when compared with the untreated control and the single treatments with APC and the tested proteasome inhibitors (Fig. 2D). These observations are consistent with previous findings in other malignancies that have attributed HDAC and proteasome inhibitor-mediated cytotoxicities to increased ROS generation $(25,44)$. Co-administration of the antioxidant, L-NAC (15 mM), substantially blocked the APC/PI-mediated increase in ROS levels (data not shown). Increased ROS production has been reported to result in protein, lipid and DNA-based oxidation with the latter forming apurinic/apyrimidic sites (among other types of DNA damage). These findings indicate that the generation of ROS plays a significant role in the APC/PI-mediated lethality in colorectal cancer cells (45).

The combined treatment of APC with MG132, PI-1, or EPM resulted in a prominent arrest of the human colorectal cancer cells in $\mathrm{G}_{1}-\mathrm{G}_{0} / \mathrm{S}-, \mathrm{G}_{2}-\mathrm{M} / \mathrm{S}-$, or $\mathrm{S}-$ phases, respectively (Fig. 3A). Exposure to other combinations of HDAC and proteasome inhibitors was also reported to induce a $\mathrm{G}_{2} / \mathrm{M}$ cell cycle arrest in different types of malignancies (25). Furthermore, APC interacted synergistically with MG132, PI-1 or EPM to induce apoptosis when compared with single treatments with APC, MG132, PI-1 and EPM or with untreated colorectal cancer cells (Fig. 3B). Such findings are in accord with those reported for other combinations of HDAC and proteasome inhibitors and in other types of malignancies $(22,46)$.

We also evaluated the molecular events that potentially led to the effectiveness of the combination of APC with the proteasome inhibitors by analyzing several signaling pathways linked to cell proliferation and apoptosis. Human colorectal cancer cells exposed to APC and MG132, PI-1, or EPM displayed a marked downregulation in the mRNA expression of genes related to cell cycle control, including $C d k 1, C d k 2$, $C d k 4, C d k 6$ and $C d c 25 A$, when compared with the single treatments with APC, MG132, PI-1 and EPM. However, the same combined treatments resulted in the upregulation of the cell cycle-dependent kinase inhibitor genes, $p 15, p 19, p 21$ and $p 27$, when compared with the single treatments (Fig. 4). These results are consistent with findings in other malignancies using various HDAC and proteasome inhibitors $(25,44,47,48)$. Increased levels of $p 15, p 19, p 21$ and $p 27$ and maintenance of the key cell cycle regulatory proteins that counter proliferative signals, eventually leading to apoptosis (49), are possible mechanisms of colorectal cancer cell death induced by the combined treatment of APC with proteasome inhibitors.

Co-exposure of human colorectal cancer cells to APC and MG132, PI-1, or EPM resulted in the overexpression of a number of pro-apoptotic genes, including Bim, Bax, Apaf1 and caspases 2, 3, 4, 7 and 9. The same combined treatments exhibited reduced mRNA expression of anti-apoptotic genes, including $B c l 2, x-I A P$ and $c-I A P-1$ (Fig. 4). These results are in agreement with those reported in other malignancies using various combinations of HDACIs and proteasome inhibitors $(25,39,44,50)$.

Bax promotes apoptosis through its interaction with the anti-apoptotic members in the mitochondria, such as Bcl-2. Such interactions have been shown to activate caspases, which cleave many vital cellular substrates, thereby contributing to cell death and the apoptotic phenotype. Caspase 9 is an initiator caspase in the apoptotic process, and its function is to activate the effector caspases 6, 7, and 3 (51).

The upregulation of pro-apoptotic genes in conjunction with the downregulation of anti-apoptotic genes as well as the increased production of ROS in colorectal cancer cells co-exposed to APC and proteasome inhibitors may serve to shift the balance from pro-survival to pro-apoptotic. The APC/PI combination regimens thus lower the threshold of colorectal cancer cells to pro-death signals, thereby accounting for the lethality of the combination regimens.

The effects of single and combined treatments of APC with proteasome inhibitors were examined in relation to perturbations of cytoprotective and stress-related signaling modules in the colorectal cancer cells. The combined APC/proteasome inhibitor treatments downregulated the levels of the phosphorylated forms of AKT and ERK $(\mathrm{P} \leq 0.0001)$ in the cancer cells. On the other hand, these combined treatments markedly augmented JNK phosphorylation ( $\mathrm{P} \leq 0.0001)$ (Fig. 5). Similar results have been reported for other malignancies using various combinations of HDAC and proteasome inhibitors $(25,39,44)$.

Several lines of evidence have suggested that the enhanced lethality of APC in conjunction with the tested proteasome inhibitor combinations stem, at least in part, from a redirection of signals away from cytoprotection and toward the stressrelated cascade. For example, in PC12 cells, the net output of the JNK and ERK pathways determines whether cells live or die in response to growth factor deprivation. Furthermore, JNK activation has been implicated in events associated with mitochondrial damage and cytochrome c release (52). For these reasons, the activation of stress-related cascades is one of the factors thought to be involved in proteasome inhibitormediated lethality (53). Thus, in colorectal cancer cells, the 
combined downregulation of ERK and AKT may be considerably more lethal than the disruption of either pathway alone.

Several of the signaling pathways affected by HDAC and proteasome inhibitors, such as the disruption of Akt signaling and the hyperactivation of JNK signaling, have been implicated in Bax regulation. Direct phosphorylation of Bax by Akt on ser ${ }^{184}$ inhibits Bax translocation to mitochondria in neutrophils (54). Alternatively, phosphorylation of Bax by JNK stimulates mitochondrial translocation (55). The effects on Bax-interacting proteins may also contribute to the effects induced by HDAC and proteasome inhibitors. Ku70 was initially identified as a component of the machinery that repairs DNA strand breaks, but it has also been shown to have an important role in sequestering Bax in the cytoplasm. Sequestration of Bax by Ku70 depends on the acetylation of several key residues within the c-terminal linker domain that is adjacent to the Bax interaction domain (54). Treating cells with an HDAC inhibitor is therefore expected to result in an accumulation of acetylated Ku70, which may be unable to sequester Bax in the cytoplasm to suppress apoptosis. Thus, it is likely that the multiple cellular changes induced by the HDACI, APC and PIs (MG132, PI-1 and EPM) in human colorectal cancer cells contribute to the activation of Bax and the subsequent induction of apoptosis.

The mechanisms by which HDAC and proteasome inhibitors exert their cytotoxic effects have not been fully delineated and are likely to be multifactorial and cell line-specific. Numerous genes are affected by proteasome inhibitors or APC, and it is therefore likely that a combination of these effects may lead to the synergy observed between the two classes of agents. Both proteasome inhibitors and APC generate ROS, either via mitochondrial injury or by disrupting antioxidant systems. When paired, these two compounds increase oxidative stress, leading to apoptosis. High levels of ROS can cause damage to proteins, a process that contributes to ER stress. Inhibiting the proteasome also results in aggregates of ubiquitin-conjugated proteins that were originally targeted for degradation by the proteolytic complex. HDACIs disrupt aggresomes, leading to ER stress (8). Thus, the combination of proteasome inhibitors (MG132, PI-1 and EPM) and the HDACI, APC, leads to increased cellular stress and apoptosis.

Both oxidative stress and disruption of aggresome formation, leading to ER stress, are important pathways that contribute to the synergy observed between proteasome inhibitors and APC. However, because both of these types of drugs have pleiotropic effects, other mechanisms may also be involved. Both HDAC and proteasome inhibitors influence many cellular processes; thus, further studies examining their interactions may reveal additional overlapping mechanisms that have not yet been identified as contributing to their synergism.

Cancer patients often develop chemoresistance, and increasing the concentrations of cytotoxic drugs fails to significantly improve the therapeutic response. One hypothesis for the development of chemoresistance is an acquired resistance of the tumor cells to apoptosis (56), allowing tumors to withstand high levels of chemotherapy. Tumor cells that are resistant to apoptosis also exhibit increased proliferative capacity.

In this study, we showed that the combined treatment of APC with the proteasome inhibitors, MG132, PI-1 or EPM, markedly reduced the apoptotic threshold of the colorectal cancer cells. These results prompted us to examine the potential of the combined treatments to augment the sensitivity of human colorectal cancer cells to standard chemotherapeutic drugs. Our data clearly indicated that the APC/proteasome inhibitor (MG132, PI-1 or EPM) combinations led to a marked increase in the sensitivity of colorectal cancer cells to standard chemotherapies in an APC/proteasome inhibitor- and colorectal cancer subtype-dependent manner (Figs. 6-10, Tables I-V). These results are in line with findings in other malignancies $(22,56-58)$.

Given the pleiotropic actions of both HDAC and proteasome inhibitors, it is unlikely that an interruption of NF- $\mathrm{kB}$ signaling is the sole basis for the synergistic interactions between such agents and the enhanced chemosensitization potential of the combination treatment.In all probability, additional mechanisms are involved. Cytotoxicity and chemosensitization potentials of the APC/proteasome inhibitor combination treatment are most likely associated with multiple interacting mechanisms, including proteasome and NF- $\mathrm{\kappa B}$ inhibition, ROS generation, cell cycle perturbation, downregulation of anti-apoptotic and cytoprotective molecules, and upregulation of pro-apoptotic and stress-related molecules. Although clinical studies of HDAC and proteasome inhibitors as single agents have yielded only modest results (59), the finding that very low concentrations of APC and a proteasome inhibitor (MG132, PI-1 or EPM) interact synergistically to kill colorectal cancer cells and potentiate their sensitivity to standard chemotherapeutic drugs suggests the need to develop novel combination therapies for treating malignant diseases, including colorectal cancer. These combinations of drugs should function through complementary mechanisms of action with a manageable toxicity and low cross resistance. In vivo studies using animal models are necessary to confirm the validity of the combinational strategy for the treatment of colorectal cancer. Furthermore, testing this strategy with a larger number of cancer cell lines would increase the value of this study.

Combination treatments may lead to better efficacy and utility of HDACIs in the clinic. However, the effects of these combinations on dose-limiting toxicities have not been thoroughly evaluated. Combination studies may therefore provide an opportunity to use lower doses and reduce dose-limiting toxicities, including the fatigue, vomiting, nausea and diarrhea (among others) that have been observed with the use of HDACIs as single agents (60). Although there are concerns that using combinations of agents may result in increased toxicities, preliminary data from current clinical trials indicate that these combinations are safe and well tolerated.

Many questions remain unanswered with respect to HDACI specificities for particular tumor subtypes and the molecular mechanisms underlying HDACI-induced cell differentiation, cell cycle arrest and apoptosis. The mechanisms that regulate specific gene expression and recruitment of HDAC complexes to specific promoter sites are also unknown. It is important to distinguish the HDAC specificity of HDACIs for the development of selective therapies at the molecular level.

\section{Acknowledgements}

This study was supported by Kuwait University, Research Grant No. [SL 05/05]. 


\section{References}

1. Heider U, Rademacher J, Lamottke B, et al: Synergistic interaction of the histone deacetylase inhibitor SAHA with the proteasome inhibitor bortezomib in cutaneous $\mathrm{T}$ cell lymphoma. Eur J Haematol 82: 440-449, 2009.

2. Marks PA and Breslow R: Dimethyl sulfoxide to vorinostat: development of this histone deacetylase inhibitor as an anticancer drug. Nat Biotechnol 25: 84-90, 2007.

3. Frew AJ, Johnstone RW and Bolden JE: Enhancing the apoptotic and therapeutic effects of HDAC inhibitors. Cancer Lett 280 $125-133,2009$.

4. Andrews KT, Walduck A, Kelso MJ, Fairlie DP, Saul A and Parsons PG: Anti-malarial effect of histone deacetylation inhibitors and mammalian tumor cytodifferentiating agents. Int J Parasitol 30: 761-768, 2000.

5. Im JY, Park H, Kang KW, Choi WS and Kim HS: Modulation of cell cycles and apoptosis by apicidin in estrogen receptor (ER)-positive and -negative human breast cancer cells. Chem Biol Interact 172: 235-244, 2008.

6. Kim MS, Son MW, Kim WB, Park YI and Moon A: Apicidin, an inhibitor of histone deacetylase, prevents $\mathrm{H}$-ras-induced invasive phenotype. Cancer Lett 157: 23-30, 2000.

7. Kwon SH, Ahn SH, Kim YK, et al: Apicidin, a histone deacetylase inhibitor, induces apoptosis and Fas/Fas ligand expression in human acute promyelocytic leukemia cells. J Biol Chem 277: 2073-2080, 2002.

8. Choi JH, Lee JY, Choi AY, et al: Apicidin induces endoplasmic reticulum stress- and mitochondrial dysfunction-associated apoptosis via phospholipase $\mathrm{C} \gamma 1-$ and $\mathrm{Ca}^{2+}$-dependent pathway in mouse Neuro-2a. Apoptosis 17: 1340-58, 2012.

9. Kobayashi H, Tan EM and Fleming SE: Acetylation of histones associated with the p21WAF1/Cipl gene transcription in human colorectal adenocarcinoma cells. Int J Cancer 109: 207-213, 2004

10. Xu Y: Regulation of p53 responses by post-translational modifications. Cell Death Differ 10: 400-403, 2003.

11. Tang G, Minemoto Y, Dibling B, Purcell NH, Li Z, Karin M and Lin A: Inhibition of JNK activation through NF- $\mathrm{BB}$ target gene. Nature 414: 313-317, 2001.

12. Verma IM, Stevenson JK, Schwartz EM, Van Antwerp D and Miyamoto S: Rel/NF- $\kappa$ B family: intimate tales of association and dissociation. Genes Dev 9: 2723-2735, 1995.

13. Huang TT, Kudo N, Yoshida M and Miyanoto S: A nuclear export signal in the $\mathrm{N}$-terminal regulatory domain of $\mathrm{I} \kappa \mathrm{B} \alpha$ controls cytoplasmic localization of inactive $\mathrm{NF}-\kappa \mathrm{B} / \mathrm{I} \kappa \mathrm{B} \alpha$ complexes. Proc Natl Acad Sci USA 97: 1014-1019, 2000.

14. Zandi E, Rothwarf DM, Delhase M, Hayakawa M and Karin M: The I $\mathrm{B}$ kinase complex (IKK) contains two kinase subunits,

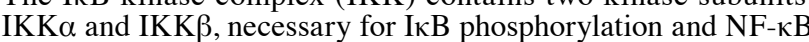
activation. Cell 91: 243-252, 1997.

15. Ghosh S, May MJ and Kopp EB: NF-кB and Rel proteins: evolutionarily conserved mediators of immune responses. Ann Rev Immunol 16: 225-260, 1998.

16. Chen L, Fischle W, Verdin E and Greene WC: Duration of nuclear $\mathrm{NF}-\kappa \mathrm{B}$ action regulated by reversible acetylation. Science 293: $1653-2657,2001$

17. Zhong H, May MJ, Jimi E and Ghosh S: The phosphorylation status of nuclear NF- $\kappa \mathrm{B}$ determines its association with $\mathrm{CBP}$ p300 or HDAC-1. Mol Cell 9: 625-636, 2002

18. Sterz J, von Metzler I, Hahne JC, et al: The potential of proteasome inhibitors in cancer therapy. Expert Opin Investig Drugs 17: 879-895, 2008.

19. Abaza MS, Al-Safar A, Al-Sawan S and Al-Attiyah R: c-myc anti-sense oligonucleotides sensitize human colorectal cance cells to chemotherapeutic drugs. Tumor Biol 29: 287-303, 2008.

20. Abaza MSI: Augmentation of the anticancer effects of proteasome inhibitors by combination with sodium butyrate in human colorectal cancer cells. Exp Ther Med 1: 675-693, 2010.

21. Lam PK, To EW, Chan ES, Liew CT, Lung IW and King WK: In vitro modulation of head and neck cell growth by human recombinant interferon $\alpha$ and 13-cis-retinoic acid. $\mathrm{Br} \mathbf{J}$ Biomed Sci 58: 226-229, 2001

22. AbazaMSI,Bahman AM,Al-AttiyahRJ and Kollamparambil AM: Synergistic induction of apoptosis and chemosensitization of human colorectal cancer cells by histone deacetylase inhibitor, scriptaid and proteasome inhibitors: potential mechanisms of action. Tumor Biol 33: 1951-1972, 2012.

23. Rosato RR and Grant S: Histone deacetylase inhibitors in clinical development. Expert Opin Investig Drugs 13: 21-38, 2004.
24. Mayo MW, Denlinger CE, Broad RM, et al: Ineffectiveness of histone deacetylase inhibitors to induce apoptosis involves the transcriptional activation of $\mathrm{NF}-\kappa \mathrm{B}$ through the Akt pathway. J Biol Chem 278: 18980-18989, 2003.

25. Dasmahapatra G, Lembersky D, Son MP, et al: Carfilzomib interacts synergistically with histone deacetylase inhibitors in mantle cell lymphoma cells in vitro and in vivo. Mol Cancer Ther 10: 1686-1697, 2011.

26. Savita B, Sriram B, Kevin D, et al: The histone deacetylase inhibitor PCI-24781 induces caspase and reactive oxygen species-dependent apoptosis through $\mathrm{NF \kappa B}$ mechanisms and is synergistic with bortezomib in lymphoma cells. Clin Cancer Res 15: 3354-3365, 2009.

27. Luu T, Chung $\mathrm{C}$ and Somlo G: Combining emerging agents in advanced breast cancer. Oncologist 16: 760-771, 2011.

28. Masdehors P, Omura S, Merle-Béral H, et al: Increased sensitivity of CCL-derived lymphocytes to apoptotic death activation by the proteasome-specific inhibitor lactacystin. Br J Haematol 105: 752-757, 1999.

29. Frankland-Searby S and Bhaumik SR: The $26 \mathrm{~S}$ proteasome complex: An attractive target for cancer therapy. Biochim Biophys Acta 1825: 64-76, 2012.

30. Adams J: The proteasome: a suitable anti-neoplastic target. Nat Rev Cancer 4: 349-360, 2004.

31. Nawrocki ST, Bruns CJ, Harbison MT, et al: Effects of the proteasome inhibitor PS-341 on apoptosis and angiogenesis in orthotopic human pancreatic tumor xenografts. Mol Cancer Ther 1: 1243-1253, 2002.

32. Yu C, Rahmani M, Conrad D, Subler M, Dent P and Grant S: The proteasome inhibitor bortezomib interacts synergistically with histone deacetylase inhibitors to induce apoptosis in $\mathrm{Bcr} / \mathrm{Abl}^{+}$ cells sensitive and resistant to ST1571. Blood 102: 3765-3774, 2003.

33. Vigushin DM and Coomes RC: Histone deacetylase inhibitors in cancer treatment. Anticancer Drugs 13: 1-13, 2002.

34. Duan J, Friedman J, Nottingham L, Chen Z, Ara G and Van Waes C: Nuclear factor- $\kappa$ p65 small interfering RNA or proteasome inhibitor bortezomib sensitizes head and neck squamous cell carcinomas to classic histone deacetylae inhibitors and novel histone deacetylase inhibitor PZD101. Mol Cancer Ther 6: 37-50, 2007.

35. Denlinger C, Keller M, Mayo M, Broad RM and Jones DR: Combined proteasome and histone deacetylase inhibition in non-small cell lung cancer. J Thorac Cardiovasc Surg 127: 1078-1086, 2004

36. Tai DI, Tsai SL, Chang YH, et al: Constitutive activation of nuclear factor kappaB in hepatocellular carcinoma. Cancer 89: 2274-2228, 2000.

37. Johnstone RW: Histone-deacetylase inhibitors: novel drugs for the treatment of cancer. Nat Rev Drug Discov 1: 287-299, 2002.

38. Yin L, Laevsky G and Giardina C: Butyrate suppression of colonocyte NF-kappa B activation and cellular proteasome activity. J Biol Chem 276: 44641-44646, 2001.

39. Jiang Y, Wang Y, Su Z, et al: Synergistic induction of apoptosis in HeLa cells by the proteasome inhibitor bortezomib and histone deacetylase inhibitor SAHA. Mol Med Rep 3: 613-619, 2010.

40. Perez-Galan P, Roue G, Villamor N, Montserrat E, Campo E and Colomer D: The proteasome inhibitor bortezomib induces apoptosis in mantle-cell lymphoma through generation of ROS and Noxa activation independent of p53 status. Blood 107: 257-264, 2006

41. Heider U, von Metzler I, Kaiser M, et al: Synergistic interaction of the histone deacetylase inhibitor SAHA with the proteasome bortezomib in mantle cell lymphoma. Eur J Haematol 80: 133-142, 2008.

42. Ling YH, Liebes L, Zou Y and Perez-Soler R: Reactive oxygen species generation and mitochondrial dysfunction in the apoptotic response to bortezomib, a novel proteasome inhibitor, in human H460 non-small cell lung cancer cells. J Biol Chem 278: 33714-33723, 2003

43. Pei XY, Dai Y and Grant S: Synergistic induction of oxidative injury and apoptosis in human multiple myeloma cells by the proteasome inhibitors bortezomib and histone deacetylase inhibitors. Clin Cancer Res 10: 3839-3852, 2004.

44. Pitts TM, Morrow M, Kaufman SA, Tentler JJ and Eckhardt SG: Vorinostat and bortezomib exert synergistic antiproliferative and proapoptotic effects in colon cancer cells models. Mol Cancer Ther 8: 342-349, 2009. 
45. Perez-Galan P, Roue G, Villamor N, Montserrat E, Campo E and Colomer D: The BH3-mimetic GX15-070 synergizes with bortezomib in mantle cell lymphoma by enhancing Noxa-mediated activation of Bak. Blood 109: 4441-4449, 2007.

46. Miller C, Ban K, Dujka ME, et al: NPI-0052, a novel proteasome inhibitor, induces caspase- 8 and ROS-dependent apoptosis alone and in combination with HDAC inhibitors in leukemia cells. Blood 110: 267-277, 2007.

47. Yu C, Friday BB, Yang L, et al: Mitochondrial Bax translocation partially mediates synergistic cytotoxicity between histone deacetylase inhibitors and proteasome inhibitors in glioma cells. Neuro Oncol 10: 309-319, 2007.

48. Orlowski RZ: The role of ubiquitin-proteasome pathway in apoptosis. Cell Death Diff 6: 303-331, 1999.

49. Buoncervello M, BorghiP, Romagnoli G, et al: Apicidin and docetaxel combination treatment drives CTCFL expression and HMGB1 release acting as potential antitumor immune response inducers in metastatic breast cancer cells. Neoplasia 14: 855-867, 2012.

50. Lawen A: Apoptosis - an introduction. Bioessays 25: 888-896, 2003.

51. Lei K, Nimmual A, Zong WX, et al: The Bax subfamily of Bcl2 related proteins is essential for apoptotic signal transduction by c- Jun NH2-terminal kinase. Mol Cell Biol 22: 4929-4942, 2002.

52. Tacchini L, Dansi P, Matteucci E, Bemelli-Zazzera A and Desiderio MA: Influence of proteasome and redox state on heat shock-induced activation of stress kinases, AP-1 and HSF. Biochim Biophy Acta 1538: 76-89, 2001.

53. Gardai SJ, Hildeman DH, Frankel SK, et al: phosphorylation of Bax Ser 184by Akt regulates its activity and apoptosis in neutrophils. J Biol Chem 279: 21085-21095, 2004.
54. Catley L, Weisberg E, Kiziltepe T, et al: Aggresome induction by proteasome inhibitor bortezomib and $\alpha$-tubulin hyperacetylation by tubulin deacetylase (TDAC) inhibitor LBH589 are synergistic in myeloma cells. Blood 108: 3441-3449, 2006.

55. Baldini E, Gardin G, Giannessi P, et al: A randomized trial of chemotherapy with or without estrogenic recruitment in locally advanced breast cancer. North-West Oncology Group (GONO) study, Italy. Tumori 83: 829-833, 1997.

56. Hwang JJ, Kim YS, Kim T, et al: A novel histone deacetylase inhibitor, CG2007745, potentiates anticancer effect of docetaxel in prostate cancer via decreasing $\mathrm{Mcl}-1$ and $\mathrm{Bcl}-(\mathrm{XL})$. Invest New Drugs 30: 1434-1442, 2011.

57. Linares A, Dalenc F, Balaguer P, Boulle N and Gavailles V: Manipulating protein acetylation in breast cancer: a promising approaching in combination with hormonal therapies? J Biomed Biotechnol 2011: 1-15, 2011.

58. Munster PN, Thurn KT, Thomas S, et al: A phase II study of the histone deacetylase inhibitor vorinostat combined with tamoxifen for the treatment of patients with hormone therapyresistant breast cancer. Br J Cancer 104: 1828-1835, 2011.

59. O'Connor OA, Heaney ML, Schwartz L, et al: Clinical experience with intravenous and oral formulations of the novel histone deacetylase inhibitor suberoylanilide hydroxamic acid in patients with advanced hematologic malignancies. J Clin Oncol 24: 166-173, 2005.

60. Vansteenkiste J, Van Cutsem E, Dumez H, et al: Early phase II trial of oral vorinostat in telapsed or refractory breast, colorectal, or non-small cell lung cancer. Invest New Drugs 26: 483-488, 2008. 